Prepared in cooperation with the Arkansas Natural Resources Commission and the Arkansas Geological Survey

\title{
Potentiometric Surfaces and Water-Level Trends in the Cockfield (Upper Claiborne) and Wilcox (Lower Wilcox) Aquifers of Southern and Northeastern Arkansas, 2009
}

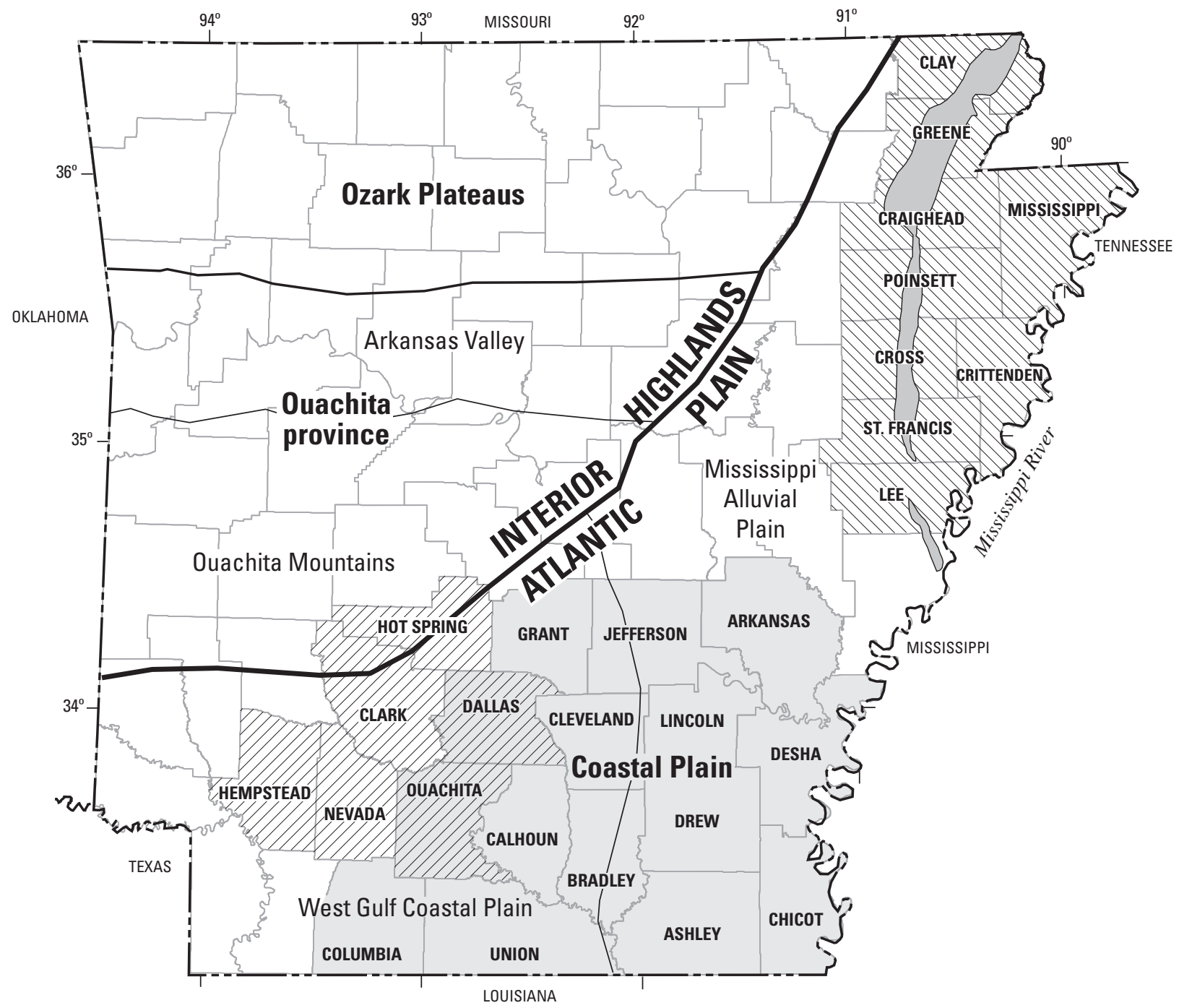

Scientific Investigations Report 2010-5014

U.S. Department of the Interior

U.S. Geological Survey 


\section{Potentiometric Surfaces and Water-Level Trends in the Cockfield (Upper Claiborne) and Wilcox (Lower Wilcox) Aquifers of Southern and Northeastern Arkansas, 2009}

By Aaron L. Pugh

Prepared in cooperation with the Arkansas Natural Resources Commission and the Arkansas Geological Survey

Scientific Investigations Report 2010-5014 


\section{U.S. Department of the Interior \\ KEN SALAZAR, Secretary \\ U.S. Geological Survey \\ Marcia K. McNutt, Director}

U.S. Geological Survey, Reston, Virginia: 2010

This and other USGS information products are available at http://store.usgs.gov/
U.S. Geological Survey
Box 25286 , Denver Federal Center
Denver, CO 80225
To learn about the USGS and its information products visit http://www.usgs.gov/
1-888-ASK-USGS

Any use of trade, product, or firm names is for descriptive purposes only and does not imply endorsement by the U.S. Government.

Although this report is in the public domain, permission must be secured from the individual copyright owners to reproduce any copyrighted materials contained within this report.

Suggested citation:

Pugh, A.L., 2010, Potentiometric surfaces and water-level trends in the Cockfield (upper Claiborne) and Wilcox (lower Wilcox) aquifers of southern and northeastern Arkansas, 2009: U.S. Geological Survey Scientific Investigations Report 2010-5014, $47 \mathrm{p}$. 


\section{Contents}

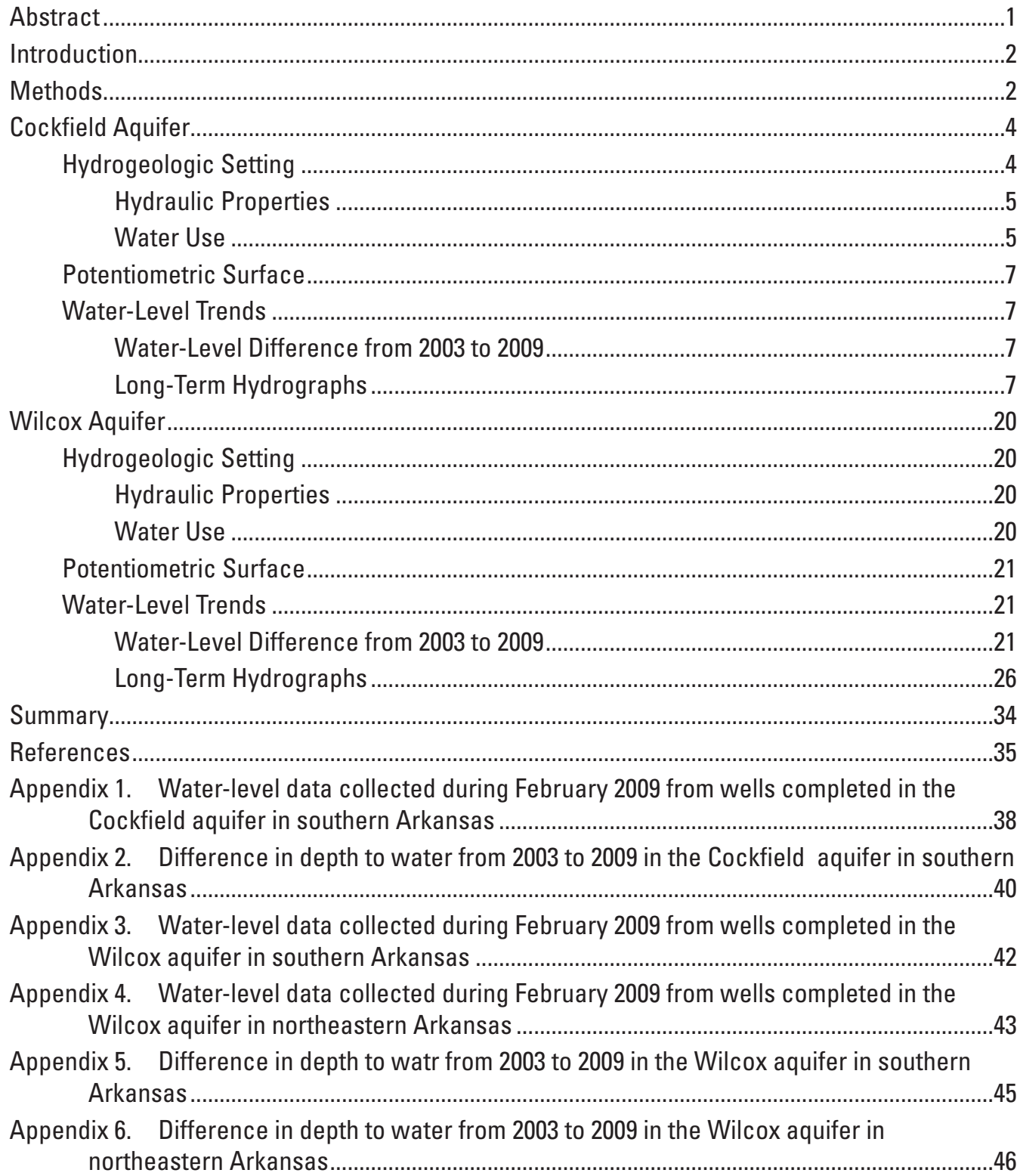




\section{Figures}

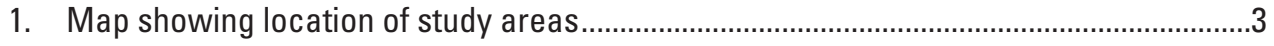

2. Diagram showing well-numbering system.....................................................................

3. Generalized section of the hydrogeologic and geologic units within the Mississippi

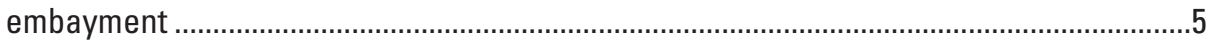

4. Graph showing water use from the Cockfield aquifer in Arkansas, 1975-2005.................7

5. Map showing potentiometric surface of the Cockfield aquifer in southern Arkansas, 2009

6. Map showing water-level difference from 2003 to 2009 of the Cockfield aquifer in southern Arkansas ............................................................................................................

7. Water-level hydrographs for selected wells completed in the Cockfield aquifer in

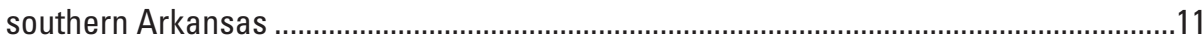

8. Graph showing water use from the Wilcox aquifer in Arkansas, 1975-2005 ...................21

9. Map showing potentiometric surface of the Wilcox aquifer in southern Arkansas,

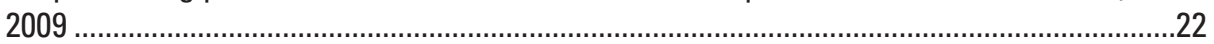

10. Map showing potentiometric surface of the Wilcox aquifer in northeastern Arkansas, 2009

11. Map showing water-level difference from 2003 to 2009 for the Wilcox aquifer in

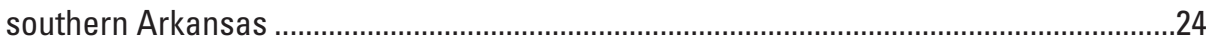

12. Map showing water-level difference from 2003 to 2009 for the Wilcox aquifer in

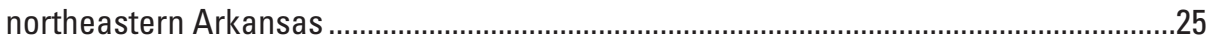

13. Water-level hydrographs for selected wells completed in the Wilcox aquifer in

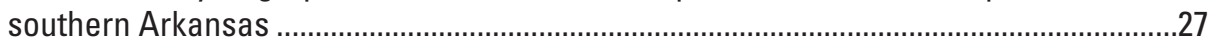

14. Water-level hydrographs for selected wells completed in the Wilcox aquifer in northeastern Arkansas

\section{Tables}

1. Hydrogeologic and geologic units within the Mississippi embayment of Arkansas ........6

2. Range, mean, and median of annual rise/decline in water level by county for wells completed in the Cockfield aquifer in Arkansas, 1990-2009.

3. Range, mean, and median of annual rise/decline in water level by county for wells completed in the Wilcox aquifer in Arkansas, 1990-2009 


\section{Conversion Factors and Datums}

\begin{tabular}{|c|c|c|}
\hline Multiply & By & To obtain \\
\hline \multicolumn{3}{|c|}{ Length } \\
\hline foot $(\mathrm{ft})$ & 0.3048 & meter $(\mathrm{m})$ \\
\hline mile (mi) & 1.609 & kilometer (km) \\
\hline \multicolumn{3}{|c|}{ Flow rate } \\
\hline million gallons per day (Mgal/d) & 0.04381 & cubic meters per second $\left(\mathrm{m}^{3} / \mathrm{s}\right)$ \\
\hline foot per year (ft/yr) & 0.3048 & meter per year $(\mathrm{m} / \mathrm{yr})$ \\
\hline \multicolumn{3}{|c|}{ Specific capacity } \\
\hline $\begin{array}{l}\text { gallon per minute per foot } \\
(\mathrm{gal} / \mathrm{min}) / \mathrm{ft})\end{array}$ & 0.2070 & $\begin{array}{l}\text { liter per second per meter } \\
(\mathrm{L} / \mathrm{s}) / \mathrm{m})\end{array}$ \\
\hline \multicolumn{3}{|c|}{ Transmissivity* } \\
\hline square foot per day $\left(\mathrm{ft}^{2} / \mathrm{d}\right)$ & 0.09290 & square meter per day $\left(\mathrm{m}^{2} / \mathrm{d}\right)$ \\
\hline
\end{tabular}

Temperature in degrees Celsius $\left({ }^{\circ} \mathrm{C}\right)$ may be converted to degrees Fahrenheit $\left({ }^{\circ} \mathrm{F}\right)$ as follows:

${ }^{\circ} \mathrm{F}=\left(1.8 x^{\circ} \mathrm{C}\right)+32$

Temperature in degrees Fahrenheit $\left({ }^{\circ} \mathrm{F}\right)$ may be converted to degrees Celsius $\left({ }^{\circ} \mathrm{C}\right)$ as follows:

${ }^{\circ} \mathrm{C}=\left({ }^{\circ} \mathrm{F}-32\right) / 1.8$

Vertical coordinate information is referenced to the National Geodetic Vertical Datum of 1929 (NGVD 1929).

Horizontal coordinate information is referenced to the North American Datum of 1983 (NAD 1983).

Altitude, as used in this report, refers to distance above the vertical datum.

Specific conductance is given in microsiemens per centimeter at 25 degrees Celsius $\left(\mu \mathrm{S} / \mathrm{cm}\right.$ at $25^{\circ} \mathrm{C}$ ).

Concentrations of chemical constituents in water are given in milligrams per liter (mg/L) or micrograms per liter $(\mu \mathrm{g} / \mathrm{L})$.

*Transmissivity: The standard unit for transmissivity is cubic foot per day per square foot times foot of aquifer thickness [(ft3/d)/ft2]ft. In this report, the mathematically reduced form, square foot per day (ft2/d), is used for convenience. 



\title{
Potentiometric Surfaces and Water-Level Trends in the Cockfield (Upper Claiborne) and Wilcox (Lower Wilcox) Aquifers of Southern and Northeastern Arkansas, 2009
}

\author{
By Aaron L. Pugh
}

\section{Abstract}

Eocene-age sand beds near the base of the Cockfield Formation of Claiborne Group constitute the aquifer known locally as the Cockfield aquifer. Upper-Paleocene age sand beds within the lower parts of the Wilcox Group constitute the aquifer known locally as the Wilcox aquifer. In 2005, reported water withdrawals from the Cockfield aquifer in Arkansas totaled 16.1 million gallons per day, while reported water withdrawals from the Wilcox aquifer in Arkansas totaled 27.0 million gallons per day. Major withdrawals from these units were for industrial and public water supplies with lesser but locally important withdrawals for commercial, domestic, and agricultural uses.

During February 2009, 56 water-level measurements were made in wells completed in the Cockfield aquifer and 57 water-level measurements were made in wells completed in the Wilcox aquifer. The results from the 2009 water-level measurements are presented in potentiometric-surface maps and in combination with previous water-level measurements.

Trends in water-level change over time within the two aquifers are investigated using water-level difference maps and well hydrographs. Water-level difference maps were constructed for each aquifer using the difference between depth to water measurements made in 2003 to 2009. Well hydrographs for each aquifer were constructed for wells with 20 or more years of historical water-level data. The hydrographs were evaluated individually using linear regression to calculate the annual rise or decline in water levels, and by aggregating the regression results by county and statistically summarizing for the range, mean, and median water-level change in each county.

The 2009 potentiometric surface of the Cockfield aquifer map indicates the regional direction of groundwater flow generally towards the east and southeast, except in two areas of intense groundwater withdrawals that have developed into cones of depression. The lowest water-level altitude measured was 43 feet and the highest water-level altitude measured was 351 feet.
A water-level difference map was constructed from 54 wells completed in the Cockfield aquifer within Arkansas. The largest rise in water level was 14.9 feet and the largest decline was 27.4 feet. Seven wells had a rise in water level, and the remaining 47 wells had a decline in water level.

Hydrographs for 33 wells completed in the Cockfield aquifer were developed. Hydrographs indicate water-level changes in individual wells ranged from rises of 0.33 feet per year to declines of 1.21 feet per year over the 20 -year period (1990-2009). County summaries of the linear regression analysis indicate Cleveland and Columbia Counties have mean annual rises. Arkansas, Ashley, Bradley, Calhoun, Chicot, Desha, Drew, Lincoln, and Union Counties have mean annual declines.

The potentiometric surface for the Wilcox aquifer is presented using two maps, one for a southern area and another for a northeastern area, because of the absence of water-level data in the central part of the State. The direction of groundwater flow in the southern area is generally the east, except around two cones of depression and around two mounds of elevated water levels. Water-level altitudes in the southern area range from 147 feet to 400 feet. The direction of groundwater flow in the northeastern area is generally to the south and southeast except in an area of intense groundwater withdrawals that has altered the flow to a westerly direction.

Two water-level difference maps were constructed using water-level altitudes measured in 2003 to 2009 from 53 wells completed in the Wilcox aquifer within southern and northeastern Arkansas. In the southern area the largest rise in water level was 16.0 feet and the largest decline was 17.7 feet. Eight wells in the southern area had rising water levels and the remaining five wells had declining water levels. In the northeastern area, the largest rise in water level was 1.3 feet and the largest decline was 21.7 feet. Four wells in the northeastern area had rising water levels, 35 wells had declining water levels, and the remaining well had no change in water level.

Hydrographs for 42 wells completed in the Wilcox aquifer were developed to show water-level altitude variation over the past 20 years. Hydrographs for the southern area 
indicate water-level changes in individual wells ranged from rises of 0.44 feet per year to declines of 1.68 feet per year over the 20-year period. County summaries of the linear regression analysis for the southern area indicate that Hot Spring County had a mean annual rise; all other counties had mean annual declines. Hydrographs for the northeastern area indicate waterlevel changes in individual wells ranged from rises of 0.51 feet per year to declines of 2.16 feet per year over the 20 -year period. County summaries of the linear regression analysis for the northeastern area indicate that Greene County had a mean annual rise; all other counties had mean annual declines.

\section{Introduction}

Eocene-age sand beds near the base of the Cockfield Formation of the Claiborne Group constitute the aquifer known locally as the Cockfield aquifer and are recognized nationally as the upper Claiborne aquifer (herein referred to as the Cockfield aquifer). Upper Paleocene-age sand beds within the lower parts of the Wilcox Group constitute the aquifer known locally as the Middle and Lower Wilcox aquifer and are recognized nationally as the lower Wilcox aquifer (herein referred to as the Wilcox aquifer). The Cockfield aquifer provides groundwater in southern Arkansas, and the Wilcox aquifer provides groundwater in southern and northeastern Arkansas. In 2005, reported withdrawals from the Cockfield aquifer in Arkansas totaled 16.1 million gallons per day (Mgal/d), and reported withdrawals from the Wilcox aquifer in Arkansas totaled 27.0 $\mathrm{Mgal} / \mathrm{d}$ (Holland, 2007). Major withdrawals from these units were for industrial and public water supplies with lesser but locally important withdrawals for commercial, domestic, and agricultural uses.

A study was conducted by the U.S. Geological Survey (USGS) in cooperation with the Arkansas Natural Resources Commission and the Arkansas Geological Survey to determine the water levels associated with the Cockfield and Wilcox aquifers in southern and northeastern Arkansas. During February 2009, 56 water-level measurements were made in wells completed in the Cockfield aquifer and 57 water-level measurements were made in wells completed in the Wilcox aquifer. The 2009 water-level measurements are presented in potentiometric-surface maps and, in combination with previous years' water-level measurements, in water-level difference maps and long-term hydrographs.

The study areas of the Cockfield and Wilcox aquifers (fig. 1) are part of the Mississippi embayment which includes much of the West Gulf Coastal Plain and the Mississippi Alluvial Plain in Arkansas. The Mississippi embayment is a north-northeast trending syncline, which plunges to the southsouthwest, which is filled with Cretaceous to recent sediments. The study area of the Cockfield aquifer in southern Arkansas is bounded on the east by the Mississippi River and on the south by the Louisiana State line. The western boundary is defined by the counties that contain outcrops and subcrops (Hosman,
1982) of the Cockfield Formation. The northern boundary is defined by counties that contain observation wells completed in the Cockfield aquifer. The study area boundary of the Wilcox aquifer in southern Arkansas is defined by the counties that contain outcrops of the Wilcox Group or observation wells completed in the Wilcox aquifer or both. The study area of the Wilcox aquifer in northeastern Arkansas is bounded on the north by the Missouri State line and on the east by the Mississippi River. The western and southern boundaries of the study area are defined by counties that contain outcrops in or near Crowleys Ridge, or observation wells that penetrate the Wilcox aquifer.

This report is the fifth in a triannual series of reports investigating the potentiometric surfaces of the Cockfield and Wilcox aquifers. Earlier reports with water-level measurements made in 2006, 2003, 2000, and 1996-1997 can be referenced through Schrader (2007), Yeatts (2004), Schrader and Joseph (2000), and Joseph (1998), respectively. The potentiometric surfaces for 1991were published in a plate map by Westerfield (1994). The previous report (Schrader, 2007) describes the potentiometric surfaces of the Cockfield and Wilcox aquifers developed from data measured during February and March of 2006. The 2006 report includes 56 water-level measurements of wells penetrating the Cockfield aquifer and 59 water-level measurements of wells penetrating the Wilcox aquifer. The 2006 report also includes analysis of 10 longterm hydrographs from the Cockfield aquifer and 7 long-term hydrographs from the Wilcox aquifer.

\section{Methods}

The well-numbering system used in this report is based upon the location of the wells according to the Public Land Survey System used in Arkansas. The component parts of a well number are the township number, the range number, the section number, three letters which indicate, respectively, the quarter section, the quarter-quarter section, and the quarterquarter-quarter section in which the well is located, and a sequence number. The letters are assigned counterclockwise, beginning with " $\mathrm{A}$ " in the northeast quarter or quarter-quarter or quarter-quarter-quarter section in which the well is located. For example, well 01S03W04BBD16 (fig. 2) is located in Township 1 South, Range 3 West, and in the southeast quarter of the northwest quarter of the northwest quarter of section 4. This well is the 16th well in this quarter-quarter-quarter section of section 4 from which data were collected.

Wells locations were verified using a Wide Area Augmentation System (WAAS) Global Positioning System (GPS) receiver to acquire the horizontal coordinate information and topographic maps to acquire land-surface altitude information. The horizontal coordinate information (latitude and longitude) of the wells was recorded using a WAAS GPS accurate to one-tenth of a second (approximately 10 to $20 \mathrm{ft}$ ), based on the North American Datum of 1983. The latitude and longitude 


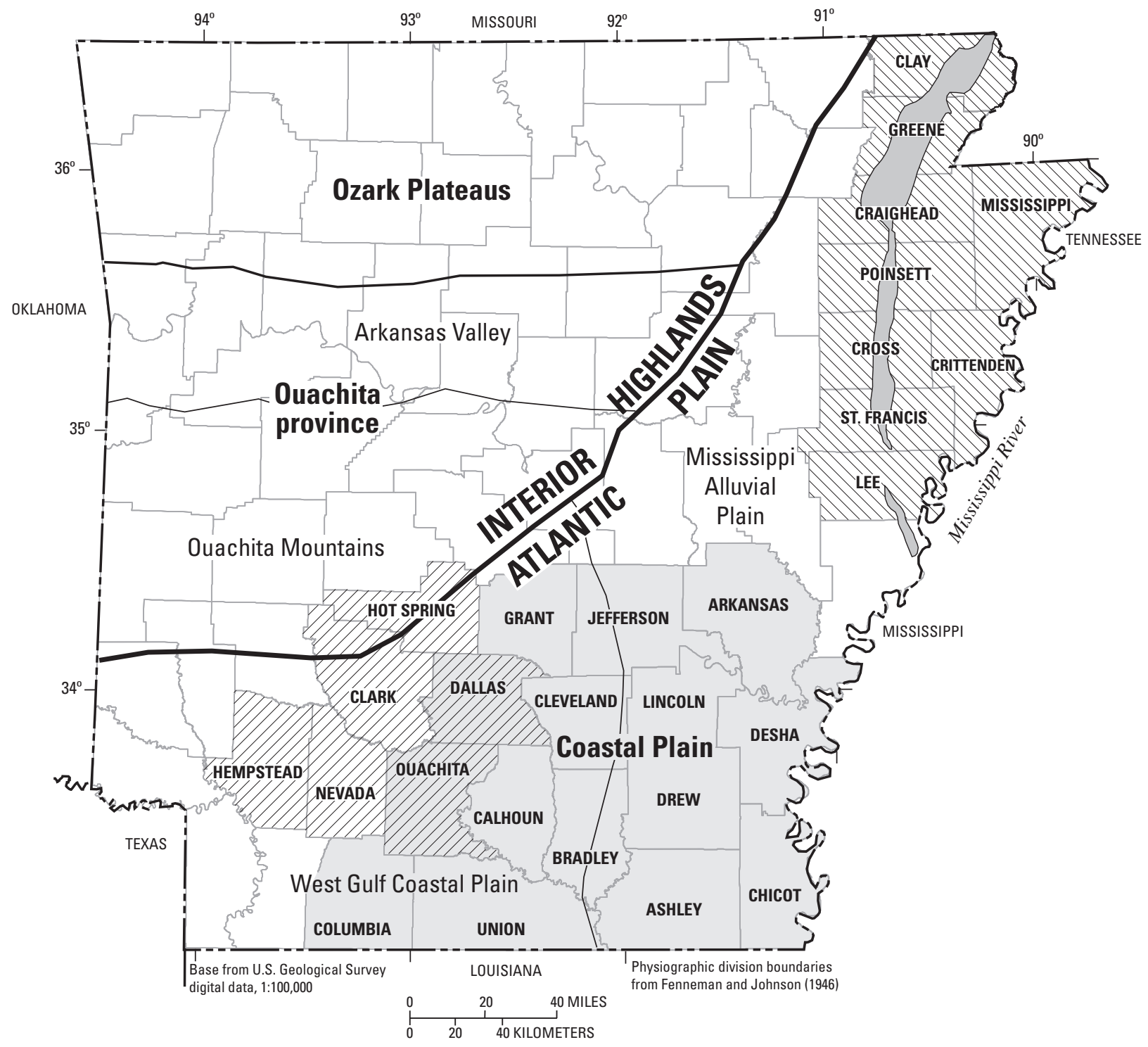

EXPLANATION

Study areas

Cockfield aquifer in southeastern Arkansas

$V / 7$ Wilcox aquifer in southwestern Arkansas

MII Wilcox aquifer in northeastern Arkansas
Crowley Ridge

Physiographic division boundary

Major Division

Province

Section

Figure 1. Location of study areas. 


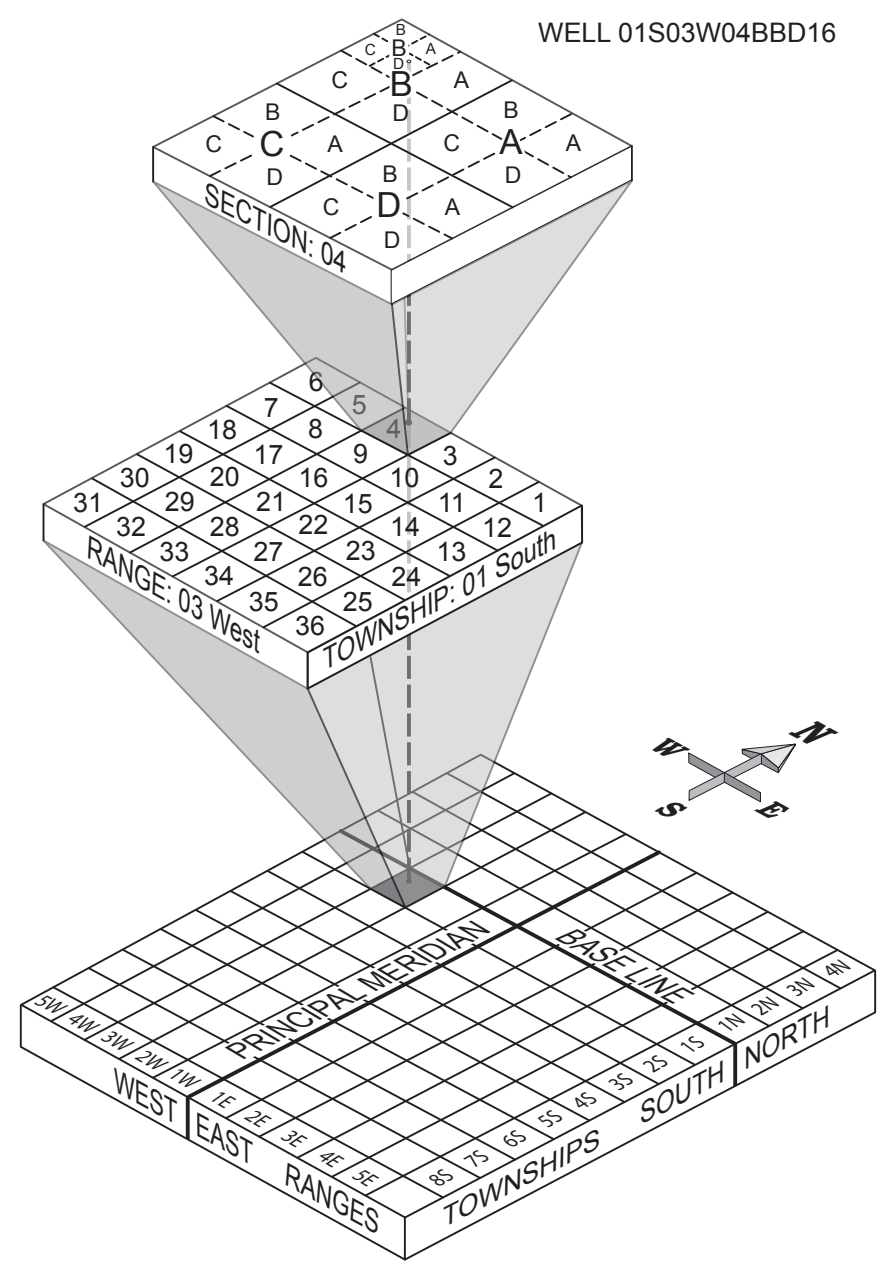

Figure 2. Well-numbering system.

of the well location was then transferred to a topographic map and the altitude of the land surface at the well was determined by interpolation of the topographic contours at the well location. The well measuring point altitude is accurate to about one-half of the contour interval $(5,10$, or $20 \mathrm{ft})$ of the topographic maps, which are based on the National Geodetic Vertical Datum of 1929.

Water levels were measured by USGS personnel at public water supply, industrial, commercial, domestic, and observation wells completed in the Cockfield or Wilcox aquifers. Measurements were made using steel or electric field tapes graduated to hundredths of a foot. The steel and electric tapes used by USGS personnel were calibrated during January 2009 prior to collecting measurements from wells. Calibration of steel and electric tapes was performed by comparing the field steel or electric tape to a standardized steel tape used only for calibration of field tapes.

Potentiometric-surface maps for the Cockfield and Wilcox aquifers in Arkansas were constructed by plotting well positions with their respective water-level altitude and manually constructing contour lines along points of equal waterlevel altitude. The altitude of the water level in each well was determined by subtracting the measured depth to water from the known land surface altitude. The direction of groundwater flow is perpendicular to the contours in the direction of decreasing water level.

Water-level difference maps for the Cockfield and Wilcox aquifers in Arkansas were constructed using the differences between depth to water measurements made during 2003 (Yeatts, 2004) to 2009. The difference in water level was calculated by subtracting the 2009 depth-to-water value from the 2003 depth-to-water value for each individual well. Positive difference values indicate a rise and negative difference values indicate a decline in water level.

Annual rises or declines in water levels were determined by performing linear regressions on the well hydrographs. The slope, $\mathrm{m}$ from the regression line equation $(\mathrm{y}=\mathrm{mx}+\mathrm{b})$ represents the daily rise or decline in water level. The annual rise or decline in water level is obtained by multiplying the slope, (daily rise or decline) by 365.25 days. The $\mathrm{R}^{2}$ term is the coefficient of determination or the fraction of variance explained by the regression (Helsel and Hirsch, 1992).

\section{Cockfield Aquifer}

\section{Hydrogeologic Setting}

The Cockfield aquifer, in southern Arkansas, is part of the Cockfield Formation of the Claiborne Group (hereafter referred to as Cockfield Formation) of Eocene age and generally consists of discontinuous fine- to medium-grained sand units interbedded with silt, clay, and lignite, all of nonmarine origin. Most of the sand beds that constitute the Cockfield aquifer media are found near the base of the Cockfield Formation and are known nationally as the upper Claiborne aquifer. The Cockfield Formation and aquifer are part of a north-northeast trending syncline, which plunges to the south-southwest, approximately centered beneath the Mississippi River (fig. 3). The Cockfield Formation generally ranges from 100 to 400 $\mathrm{ft}$ thick near outcrop areas and thickens downdip towards the center of the syncline, reaching $625 \mathrm{ft}$ thick in northeastern Chicot County (Onellion and Criner, 1955). Thicknesses of the sand beds near the base of the Cockfield Formation that compose the Cockfield aquifer generally range from 20 to 150 $\mathrm{ft}$. The Cockfield Formation is underlain throughout the study area by calcareous and sandy marl, limestone, and carbonaceous clay of the Cook Mountain Formation of Claiborne Group (table 1). The Cockfield Formation is overlain by silty clays of the Jackson Group throughout much of southeastern Arkansas. In the confined part of the aquifer, the potentiometric surface can be near or above land surface. Sand beds at the base of the overlying Jackson Group in parts of southeastern Arkansas may be in hydraulic connection with the Cockfield aquifer (Ackerman, 1987). 


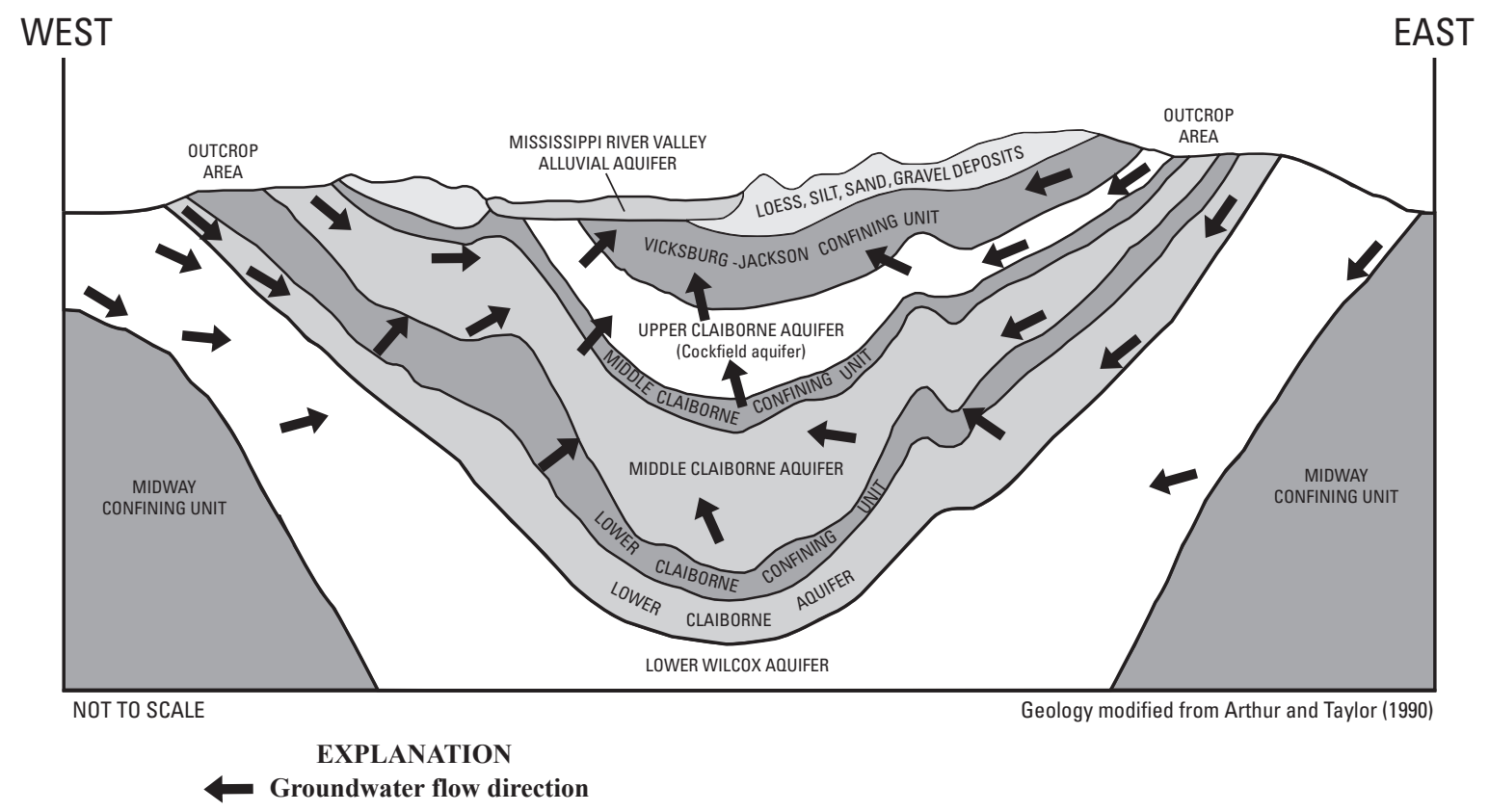

Figure 3. Generalized section of the hydrogeologic and geologic units within the Mississippi embayment (modified from Hart and others, 2008).

The Cockfield Formation and aquifer outcrop in a band trending north-northeast across the study area and dip southeastward. In the subcrop area, the Cockfield Formation is overlain by terrace deposits and alluvium of Quaternary age. The terrace deposits may attain a thickness of $40 \mathrm{ft}$, and as much as $60 \mathrm{ft}$ of alluvium overlies the Cockfield Formation in some of the larger river valleys.

Most recharge to the Cockfield aquifer occurs by infiltration of rainfall on the upland outcrop areas and by inflow from the overlying alluvium or rivers that have eroded through the overburden and are hydrologically connected with the aquifer. Most discharge is to rivers in outcrop areas, to vertically adjacent units where the Cockfield aquifer is confined, and to wells (Ackerman, 1987). Well depths are shallow (less than $200 \mathrm{ft}$ ) and yields of most wells in the outcrop areas are small, less than 30 gallons per minute (gal/min), but in other areas downdip from the outcrop areas, wells screening the full thickness of the aquifer often yield 100 to $500 \mathrm{gal} / \mathrm{min}$ (Westerfield, 1994).

\section{Hydraulic Properties}

Specific capacity and transmissivity values are variable for the Cockfield aquifer. The following values are based on single-well pump tests and multiple-well aquifer tests (Pugh, 2008). Specific capacity values ranged from 0.15 gallon per minute per foot $(\mathrm{gal} / \mathrm{min} / \mathrm{ft})$ to $23.7 \mathrm{gal} / \mathrm{min} / \mathrm{ft}$ with a median of $0.76 \mathrm{gal} / \mathrm{min} / \mathrm{ft}$. Transmissivity values ranged from 325 square feet per day $\left(\mathrm{ft}^{2} / \mathrm{d}\right)$ to $6,280 \mathrm{ft}^{2} / \mathrm{d}$ with a median of 3,350 $\mathrm{ft}^{2} / \mathrm{d}$. Hydraulic conductivity values were not provided by any of the well tests associated with the Cockfield aquifer. Pugh
(2008) estimated a hydraulic conductivity value for the Cockfield aquifer by dividing the mean transmissivity value $(3,330$ $\mathrm{ft}^{2} / \mathrm{d}$ ) by the maximum aquifer thickness ( $400 \mathrm{ft}$ ), providing an estimated hydraulic conductivity value of $8.33 \mathrm{ft} / \mathrm{d}$.

\section{Water Use}

Withdrawals from the Cockfield aquifer in the study area during 2005 totaled about $16.1 \mathrm{Mgal} / \mathrm{d}$ (Holland, 2007) (fig. 4). Withdrawals from the Cockfield aquifer have continued to rise from 1985 to 2005 , producing $5.0 \mathrm{Mgal} / \mathrm{d}$ in $1985,8.1$ $\mathrm{Mgal} / \mathrm{d}$ in 1990, $9.8 \mathrm{Mgal} / \mathrm{d}$ in 1995, $9.9 \mathrm{Mgal} / \mathrm{d}$ in 2000, and 16.1 Mgal/d in 2005 (Holland 1987, 1993, 1999, 2004, 2007). Withdrawals from the Cockfield aquifer were $5.2 \mathrm{Mgal} / \mathrm{d}$ in 1975 and 7.2 Mgal/d in 1980 (Halberg, 1977; Holland and Ludwig, 1981). The increase in withdrawals between 2000 (9.9 Mgal/d) and $2005(16.1 \mathrm{Mgal} / \mathrm{d})$ are associated with increased use of waters from the Cockfield aquifer by public supply systems in eastern Arkansas (T.W. Holland, U.S. Geological Survey written commun., 2009). Most wells completed in the Cockfield aquifer study area provide small volumes of water for domestic and livestock use. In some locations, the Cockfield aquifer yields volumes large enough to supply industrial and public supply systems.

Adjacent to Arkansas, in 2005 about $46 \mathrm{Mgal} / \mathrm{d}$ were withdrawn from the Cockfield aquifer in Mississippi (D.E. Burt, U.S. Geological Survey, written commun., 2009). Withdrawals from the Cockfield aquifer in Mississippi increased 170 percent between 1999 and 2005. Immediately across the Mississippi River from Chicot County, Arkansas, the city of Greenville, Mississippi, withdrew about $22 \mathrm{Mgal} / \mathrm{d}$ from the 
Table 1. Hydrogeologic and geologic units within the Mississippi embayment of Arkansas (modified from Hart and others, 2008).

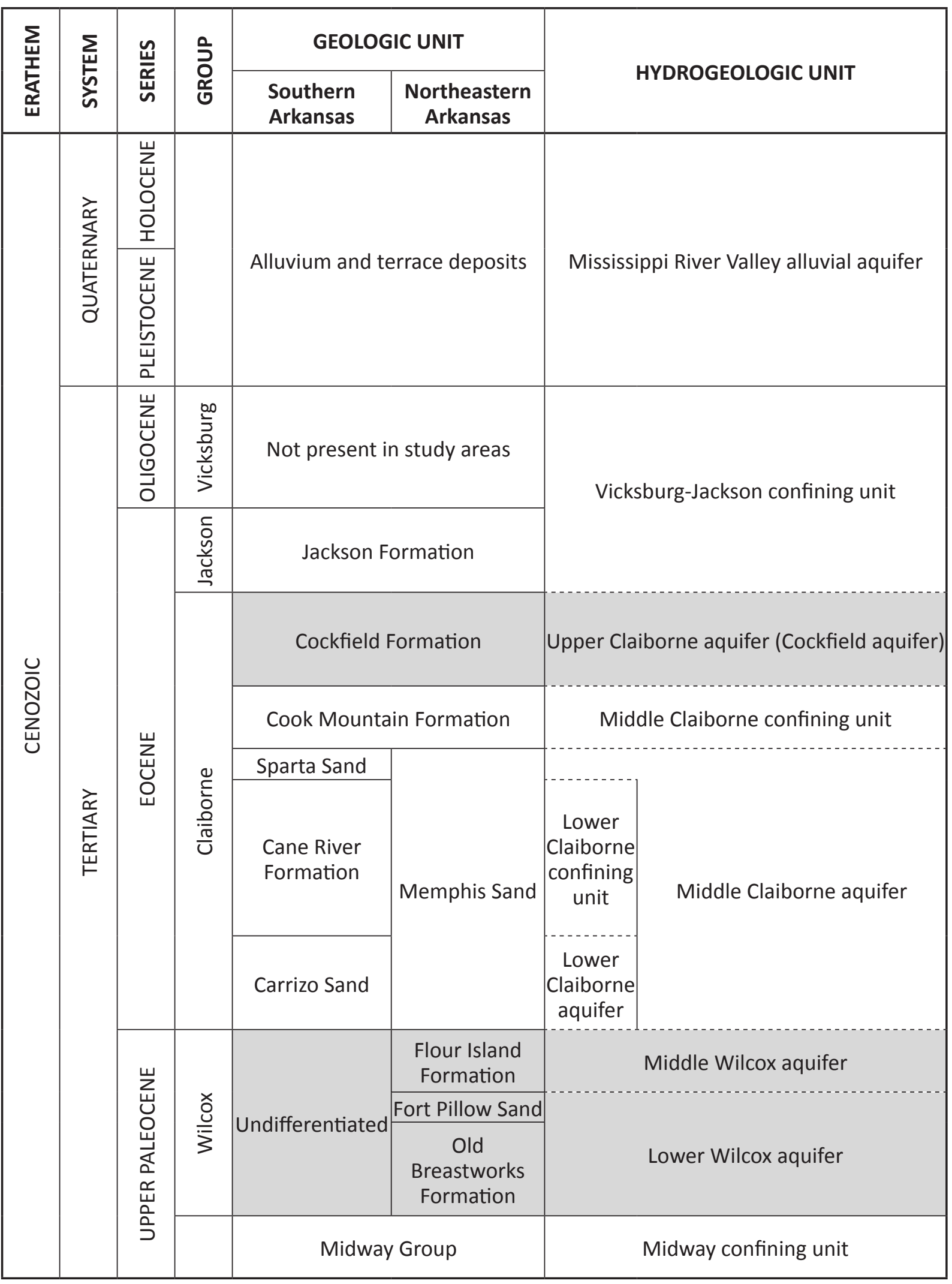

Modified from Hosman and Weiss, 1991 
Cockfield aquifer in 2005 (D.E. Burt, U.S. Geological Survey, written commun., 2009), or about 37 percent more than was withdrawn from the Cockfield aquifer in all of Arkansas in 2005. The large amount of withdrawal from the Cockfield aquifer in Mississippi probably contributes to lower water levels in southeastern Arkansas (Ackerman, 1987; Joseph, 1998; Schrader and Joseph, 2000).

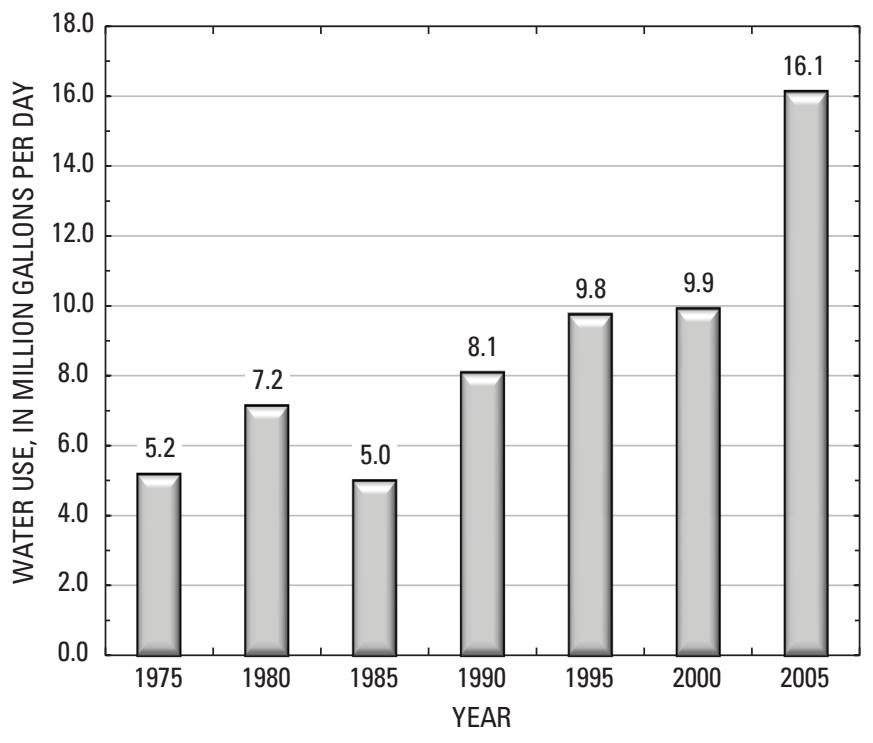

Data compiled from Halberg, 1977; Holland and Ludwig, 1981; and Holland,1987, 1993, 1999, 2004, 2007

Figure 4. Water use from the Cockfield aquifer in Arkansas, 1975-2005.

\section{Potentiometric Surface}

The potentiometric-surface map shows the altitude of the water surface in tightly cased wells screened in the Cockfield aquifer (fig. 5). The map is based upon water-level data collected during February 2009 from 56 wells completed in the Cockfield aquifer in southern Arkansas (appendix 1).

The regional direction of groundwater flow generally is towards the east and southeast, except in areas of intense groundwater withdrawals, such as western Drew County, southeastern Lincoln County and near Crossett in Ashley County (Schrader and Joseph, 2000). There are two cones of depression indicated by relatively low water levels in southwestern Calhoun County and near Crossett in Ashley County. The cone of depression in southwestern Calhoun County is associated with a depression in the top surface of the Cockfield formation (Hart and others, 2008). The cone of depression near Crossett in Ashley County is associated with groundwater withdrawals. There are also two groundwater mounds indicated by relatively high water levels in central Cleveland County and bordering Ashley and Drew Counties. The lowest water-level altitude measured was $43 \mathrm{ft}$ above NGVD of 1929 in Lincoln County; the highest water-level altitude measured was $351 \mathrm{ft}$ above NGVD of 1929 in Columbia County.

\section{Water-Level Trends}

\section{Water-Level Difference from 2003 to 2009}

A water-level difference map (fig. 6) was constructed to spatially evaluate the short-term (6 years) change in water levels of the Cockfield aquifer within Arkansas. The water-level difference map was constructed using the difference between water-level measurements made in 2003 (Yeatts, 2004) and 2009 for 54 wells completed in the Cockfield aquifer within Arkansas. Positive values, represented with blue, upward pointing triangles, indicate a rise in water level between 2003 and 2009; whereas negative values, represented with red, downward pointing triangles, indicate a decline in water level between 2003 to 2009 . The triangles are scaled in size to the relative value of rise or decline. The 2003 to 2009 waterlevel difference map does not necessarily equate to long-term trends, but is intended to show how water levels in the Cockfield aquifer have changed over the short term.

The 2003 to 2009 difference in water levels for the Cockfield aquifer within Arkansas ranged from -27.4 to 14.9 $\mathrm{ft}$ (fig. 6). The largest rise (14.9 ft) in water level was in Drew County. The largest decline (27.4 ft) was in Lincoln County. Of the 54 well data points presented, 7 wells had a rise in water level, the remaining 47 wells had a decline in water level from 2003 to 2009. Most of the declines in water levels between 2006 and 2009 were $4 \mathrm{ft}$ or less. Rises in water levels occurred in Bradley, Calhoun, Chicot, Cleveland, Drew, and Union Counties. Declines in water levels occurred in Arkansas, Ashley, Bradley, Calhoun, Chicot, Cleveland, Columbia, Desha, Lincoln, and Union.

One area, northern Cleveland County, had a slight rise in water levels in the Cockfield aquifer from 2003 to 2009 (fig. 6). Parts of northern Cleveland County are within an outcrop area of the Cockfield Formation and the area is on the northwestern flank of a groundwater mound (fig. 5). The outcrop areas provide recharge to the Cockfield aquifer and the groundwater mound separates the area from the falling water levels to the south.

The remaining areas of the Cockfield aquifer study have general decline in water levels from 2003 to 2009 (fig. 6). Large declines in water levels have occurred along the eastern and southern Arkansas borders. In Arkansas, Desha, and Chicot Counties, on or near the eastern border, water levels generally have declined 2 to $4 \mathrm{ft}$. In Columbia County, along the southern border, water levels generally have declined 3.5 to $6 \mathrm{ft}$. Water levels in the remaining parts of the Cockfield aquifer study area generally have declined 1 to $3 \mathrm{ft}$.

\section{Long-Term Hydrographs}

Two methods are used to evaluate long-term water-level trends for the Cockfield aquifer in Arkansas. The first method was to develop hydrographs for each well with 20 or more 

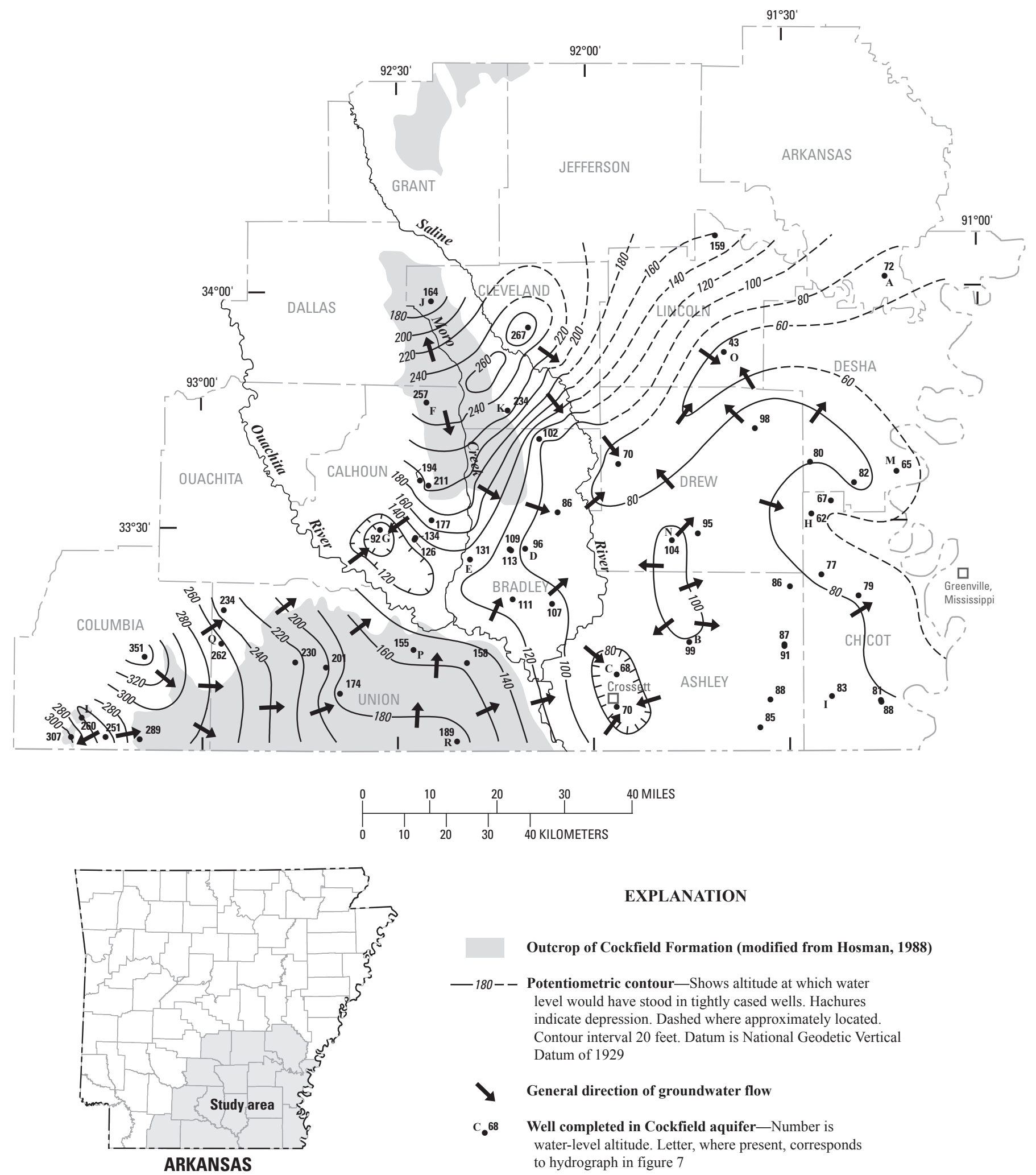

EXPLANATION

Outcrop of Cockfield Formation (modified from Hosman, 1988)

- 180-- Potentiometric contour-Shows altitude at which water level would have stood in tightly cased wells. Hachures indicate depression. Dashed where approximately located. Contour interval 20 feet. Datum is National Geodetic Vertical Datum of 1929

General direction of groundwater flow

C. 68 Well completed in Cockfield aquifer-Number is water-level altitude. Letter, where present, corresponds to hydrograph in figure 7

Figure 5. Potentiometric surface of the Cockfield aquifer in southern Arkansas, 2009. 

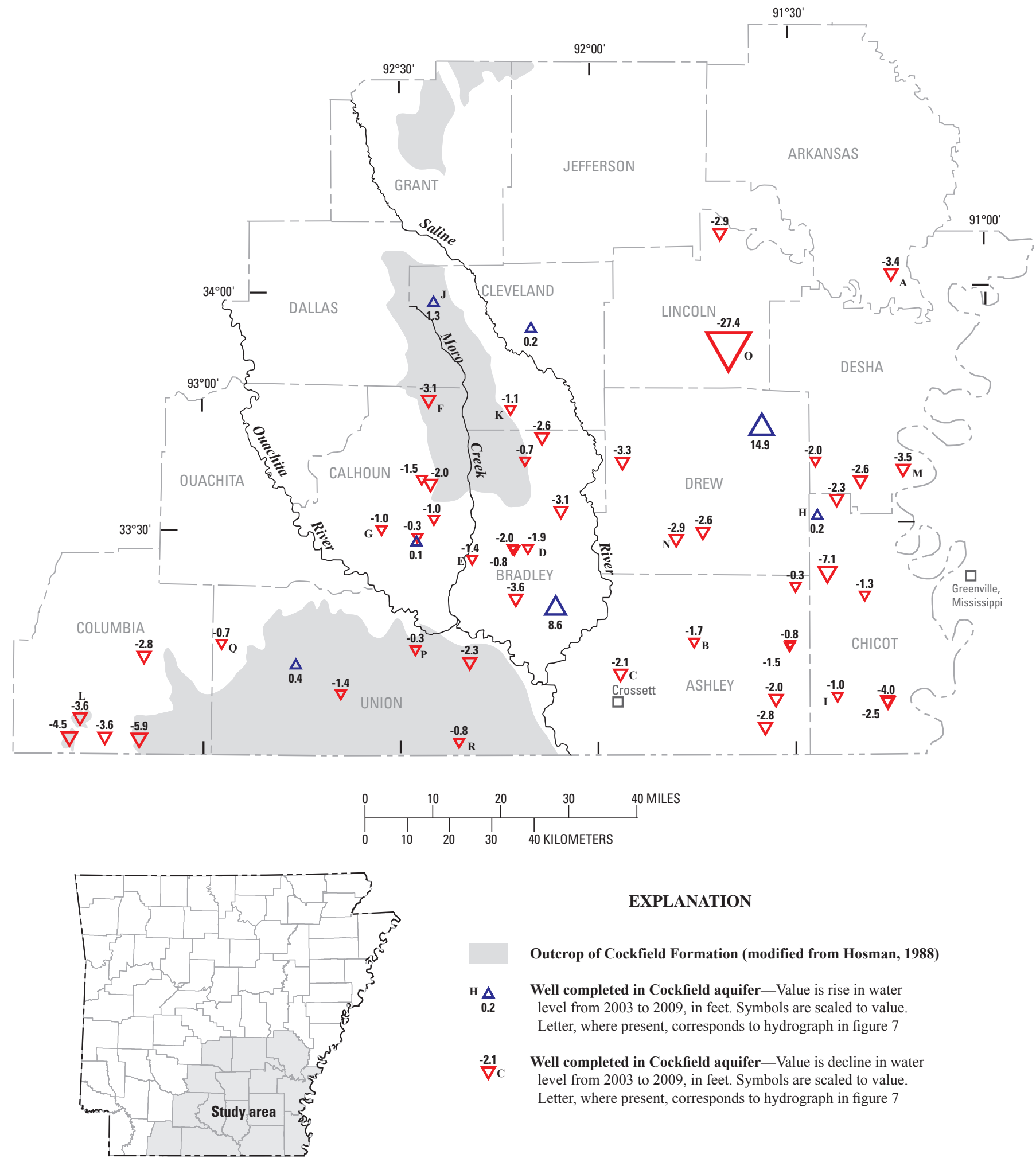

EXPLANATION

Outcrop of Cockfield Formation (modified from Hosman, 1988)

н $\Delta$ Well completed in Cockfield aquifer-Value is rise in water level from 2003 to 2009, in feet. Symbols are scaled to value. Letter, where present, corresponds to hydrograph in figure 7

$\stackrel{-2.1}{\nabla c} \quad$ Well completed in Cockfield aquifer-Value is decline in water level from 2003 to 2009, in feet. Symbols are scaled to value. Letter, where present, corresponds to hydrograph in figure 7

Figure 6. Water-level difference from 2003 to 2009 of the Cockfield aquifer in southern Arkansas. 
years of records by plotting the water-level values in relation to time (fig. 7). The second method was to calculate the annual rise or decline in water levels over the past 20 years (19902009), aggregate the data by county, and statistically evaluate the range, mean, and median of water-level change in each county (table 2).

Hydrographs for 33 wells with 20 or more years of historical water-level data were developed and examined. Selected hydrographs for 18 wells are presented in figure 7 (wells A-R). The locations of these wells are plotted on figures 5 and 6 and are designated by the letters A through $R$ next to the well location.

Examination of the hydrographs is divided into three geographic areas: the area south and west of the Ouachita River, the area between the Ouachita and Saline Rivers, and the area east of the Saline River. The area south and west of the Ouachita River, including Columbia (fig.7-L) and Union (fig. 7-P, -Q, and -R) Counties, contains an outcrop area with overlying Quaternary-age terrace deposits along the western edge. All of these hydrographs are relatively flat indicating only a small, 1 - to 3 - $\mathrm{ft}$ drop in water levels over the past 30 to 40 years. The hydrograph for well 17S13W17DDC1 (fig. 7-P) in Union County has a water-level rise of approximately $3 \mathrm{ft}$ over the more than 40-year period of record. The area between the Ouachita and Saline Rivers, including Bradley (fig. 7-D and -E), Calhoun (fig. 7-F and -G), and Cleveland (fig. 7-J and -K) Counties, is a mixed area with the northern part being in an outcrop area, the eastern part being confined by the Eocene-age Jackson Group (confining unit), and the southern part underlying Quaternary-age terrace deposits.
These hydrographs display both rises and declines ranging from a decline of approximately $20 \mathrm{ft}$ (well 14S10W31DBA1, fig. 7-D) over the period of record to rises of approximately 2 $\mathrm{ft}$ (well 15S12W11CAB1, fig. 7-E and well 11S11W23BBD1, fig. 7-K) over the period of record. The area east of the Saline River, including Arkansas (fig. 7-A), Ashley (fig. 7-B and -C), Chicot (fig. 7-H and -I), Desha (fig. 7-M), Drew (fig. 7-N), and Lincoln (fig. 7-O) Counties, is within a confined part of the aquifer. These hydrographs all show declining water levels over their period of record ranging from approximately $60 \mathrm{ft}$ (Well 10S05W06CAC1, fig. 7-O) to approximately $5 \mathrm{ft}$ (well 18S03W14CCC1, fig. 7-I).

Hydrographs for 33 wells with historical water-level data from 1990 to 2009 were evaluated using linear regression to calculate the annual rise or decline for each well and the data aggregated by county and statistically evaluated for the range, mean, and median of water-level change in each county (table 2). Arkansas, Columbia, Desha, Drew, and Lincoln Counties only had one well with a minimum of 20 years of record. Of the counties with more than one well with over 20 years of record, annual rise-decline calculations associated with wells in Ashley and Chicot Counties indicated declining water levels. Annual rise-decline calculations associated for wells with over 20 years of record in the remaining counties, Bradley, Calhoun, Cleveland, and Union, indicate both rising and declining water levels. Cleveland and Columbia Counties have mean annual water-level rises of 0.11 and $0.03 \mathrm{ft} / \mathrm{yr}$, respectively. Arkansas, Ashley, Bradley, Calhoun, Chicot, Desha, Drew, Lincoln, and Union Counties have mean annual well water-level declines ranging from 0.02 to $1.46 \mathrm{ft} / \mathrm{yr}$ (table 2).

Table 2. Range, mean, and median of annual rise/decline in water level by county for wells completed in the Cockfield aquiifer in Arkansas, 1990-2009.

[Annual rise or decline in water level for each well is calculated using linear regression; negative value indicates decline; positive value indicates rise; $\mathrm{R}^{2}$ : coefficient of determination]

\begin{tabular}{|c|c|c|c|c|c|}
\hline County & Number of wells & $\begin{array}{l}\text { Range or values of } \\
\text { annual rise (+) or } \\
\text { decline (-) in water } \\
\text { level (feet/year) }\end{array}$ & $\begin{array}{l}\text { Mean annual rise (+) } \\
\text { or decline (-) in wa- } \\
\text { ter level (feet/year) }\end{array}$ & $\begin{array}{c}\text { Median annual rise } \\
(+) \text { or decline }(-) \text { in } \\
\text { water level (feet/ } \\
\text { year) }\end{array}$ & $\begin{array}{l}\text { Range of } R^{2} \text { values } \\
\text { for trend lines }\end{array}$ \\
\hline Arkansas $^{1}$ & 1 & -0.11 & -0.11 & -0.11 & 0.08 \\
\hline Ashley & 6 & -0.69 to -0.07 & -0.44 & -0.49 & 0.02 to 0.94 \\
\hline Bradley & 4 & -0.44 to 0.26 & -0.17 & -0.26 & 0.21 to 0.91 \\
\hline Chicot & 5 & -0.77 to -0.22 & -1.46 & -0.33 & 0.46 to 0.91 \\
\hline Cleveland & 2 & -0.11 to 0.33 & 0.11 & 0.11 & 0.29 to 0.71 \\
\hline Columbia $^{1}$ & 1 & 0.03 & 0.03 & 0.03 & 0.01 \\
\hline Desha $^{1}$ & 1 & -1.21 & -1.21 & -1.21 & 0.87 \\
\hline
\end{tabular}

\footnotetext{
${ }^{1}$ County included only one well with 20 or more years of measurements.
} 


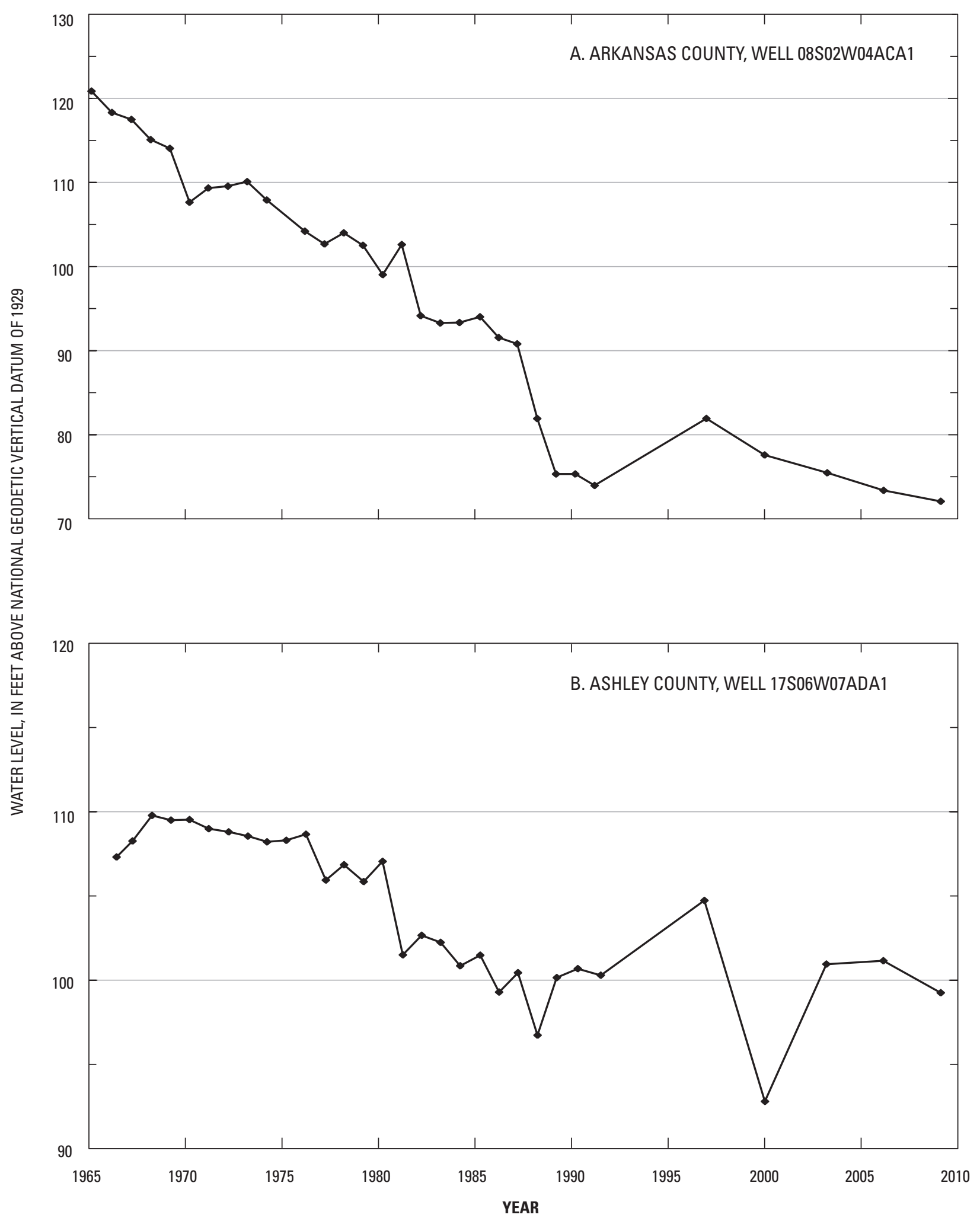

Figure 7. Water-level hydrographs for selected wells completed in the Cockfield aquifer in southern Arkansas. 

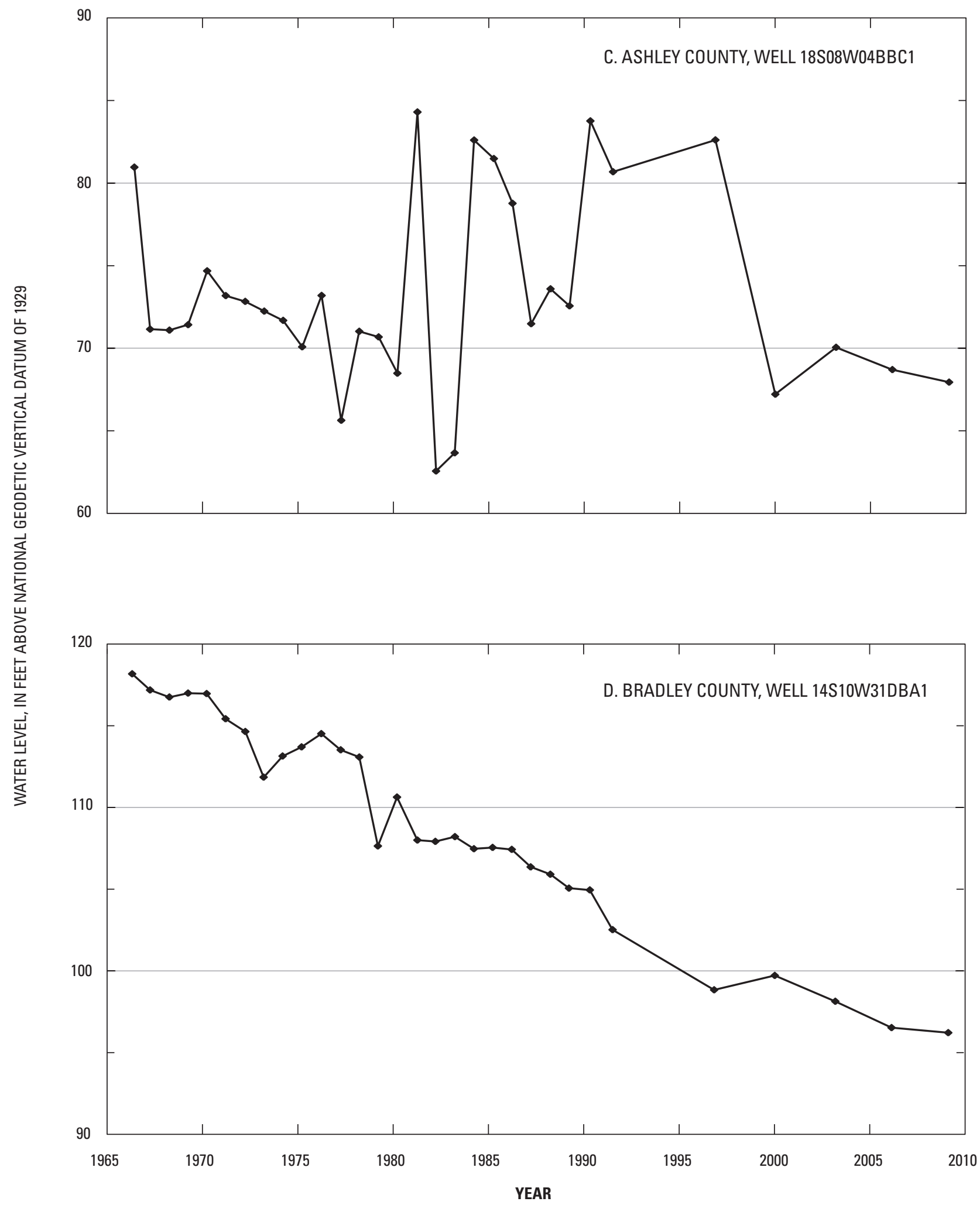

Figure 7. Water-level hydrographs for selected wells completed in the Cockfield aquifer in southern Arkansas.—Continued 


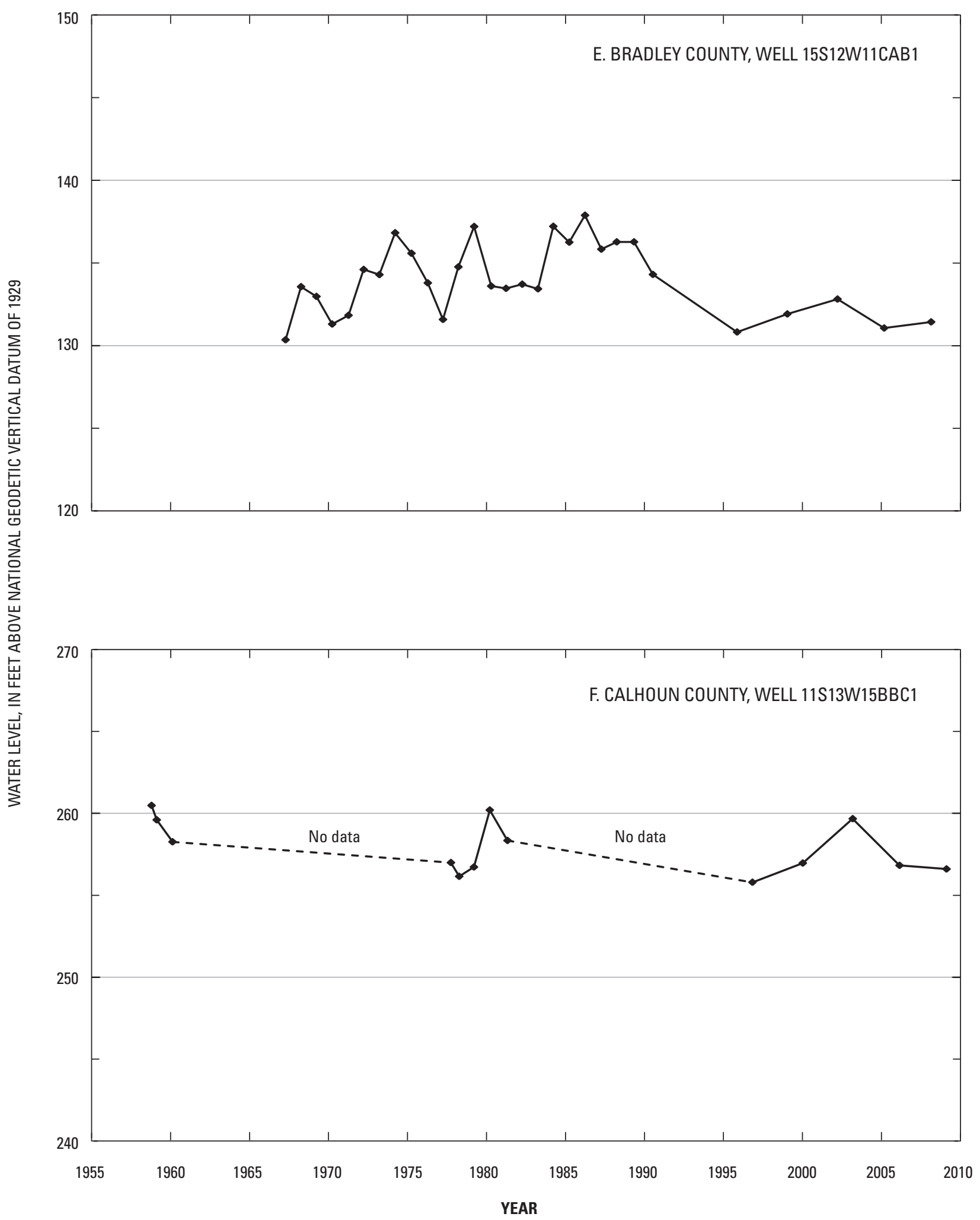

Figure 7. Water-level hydrographs for selected wells completed in the Cockfield aquifer in southern Arkansas.-Continued 


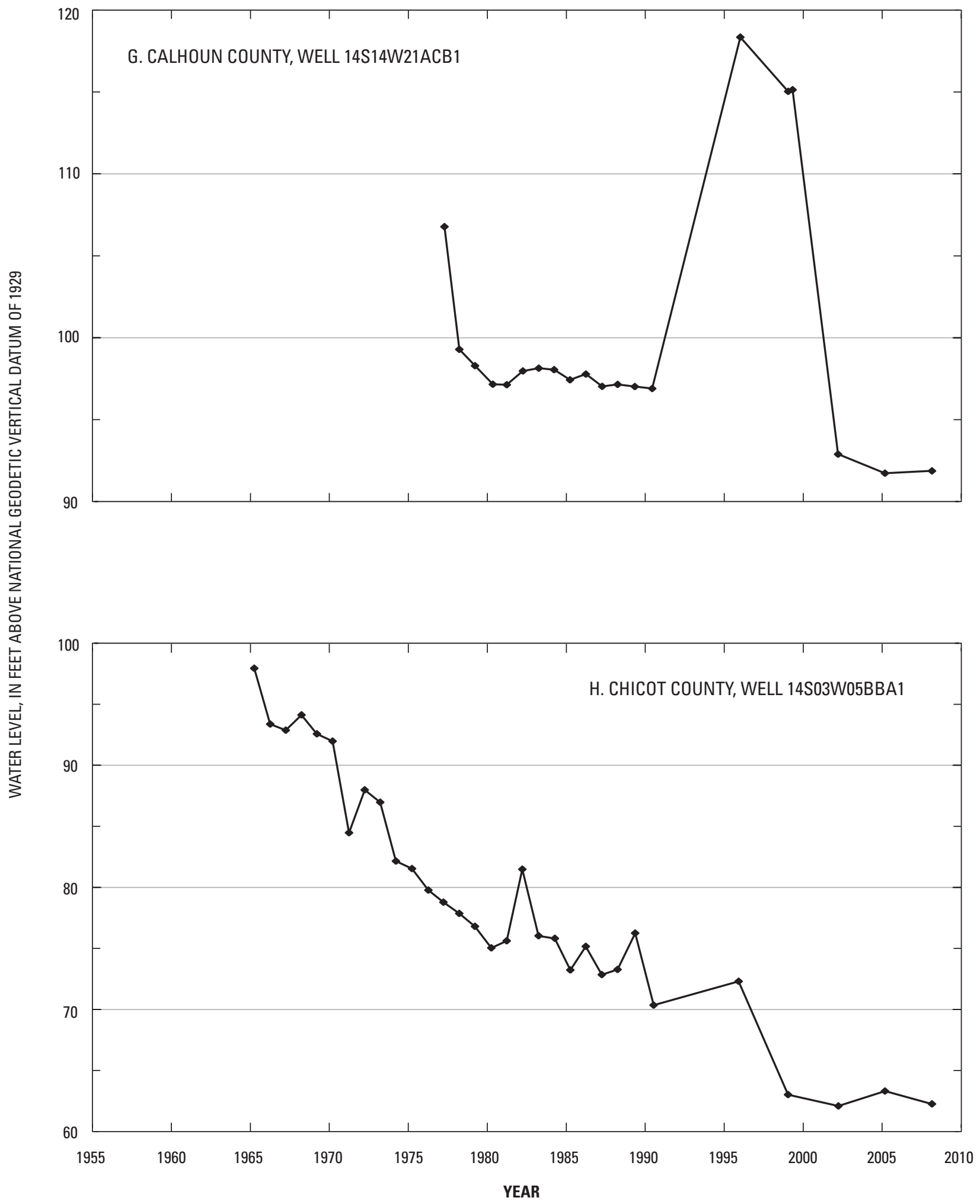

Figure 7. Water-level hydrographs for selected wells completed in the Cockfield aquifer in southern Arkansas.—Continued 


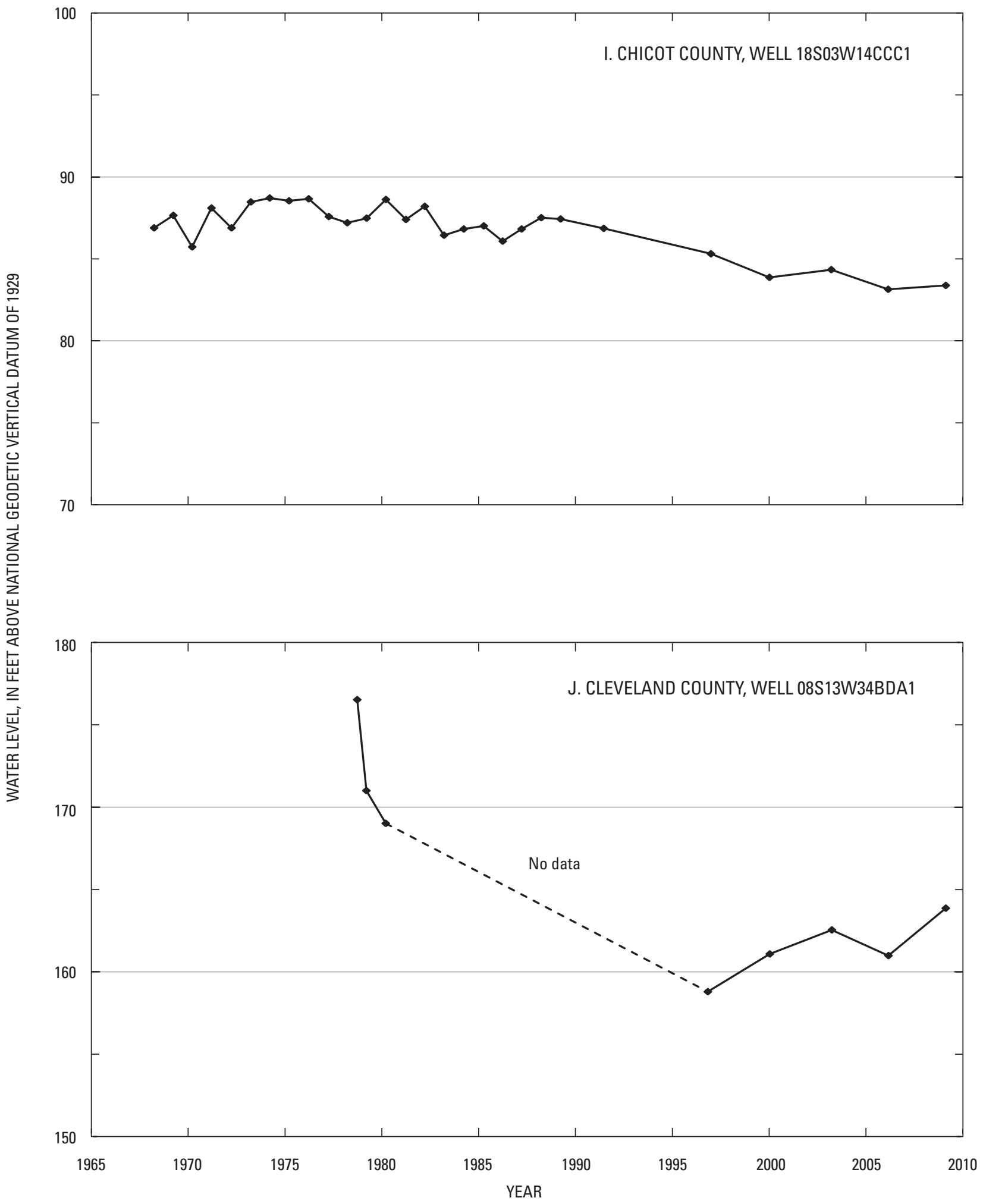

Figure 7. Water-level hydrographs for selected wells completed in the Cockfield aquifer in southern Arkansas.-Continued 


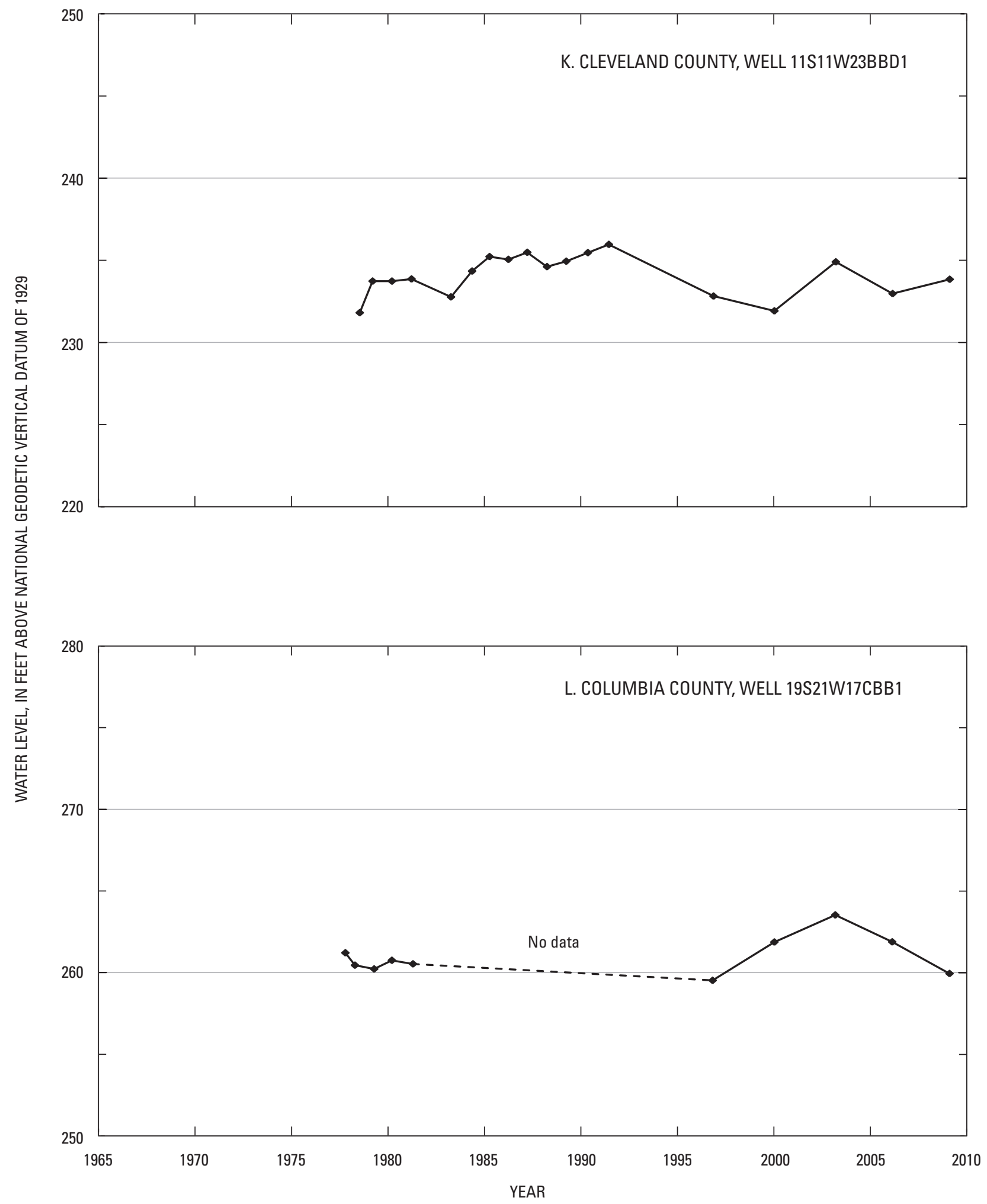

Figure 7. Water-level hydrographs for selected wells completed in the Cockfield aquifer in southern Arkansas.—Continued 


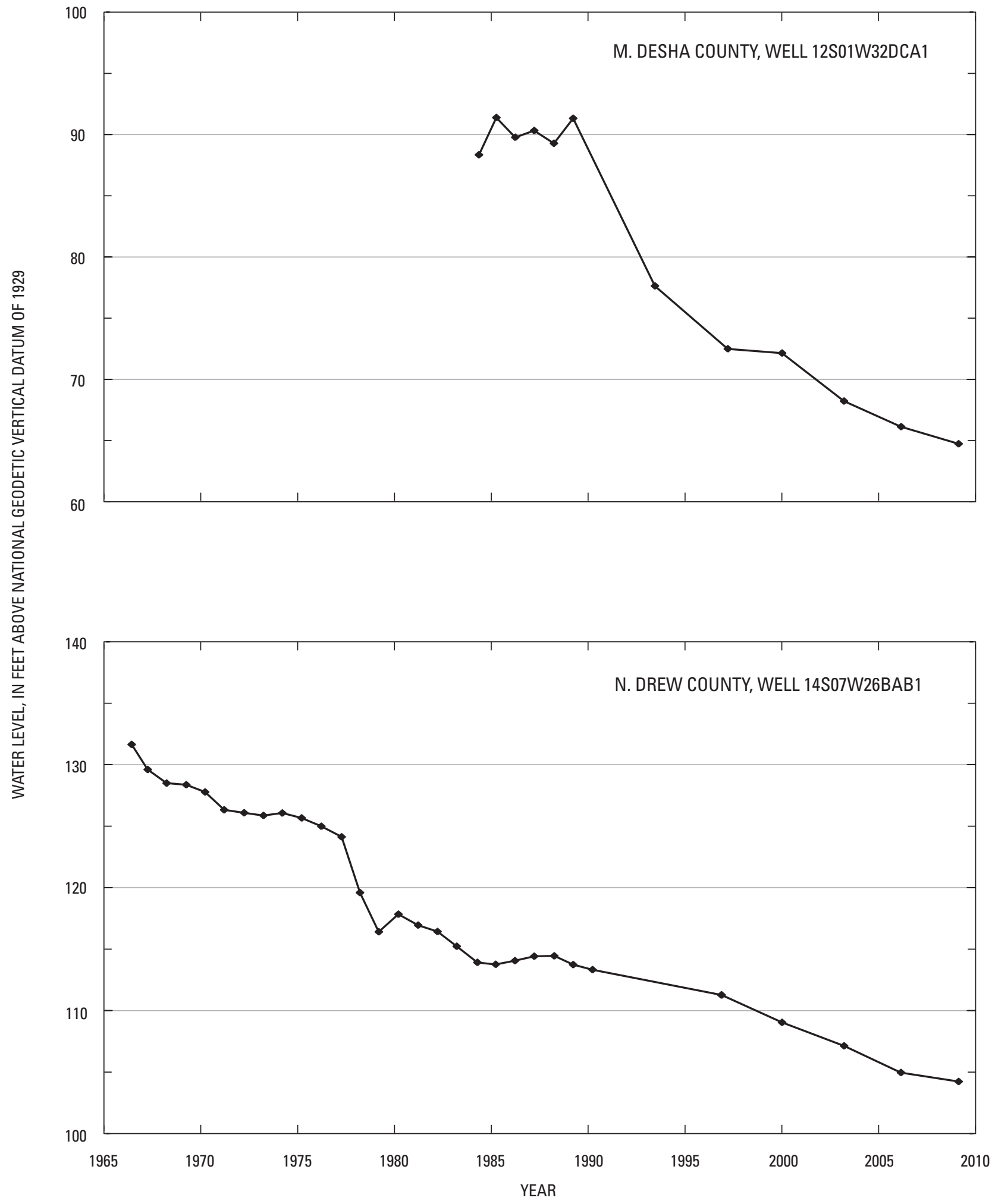

Figure 7. Water-level hydrographs for selected wells completed in the Cockfield aquifer in southern Arkansas.-Continued 


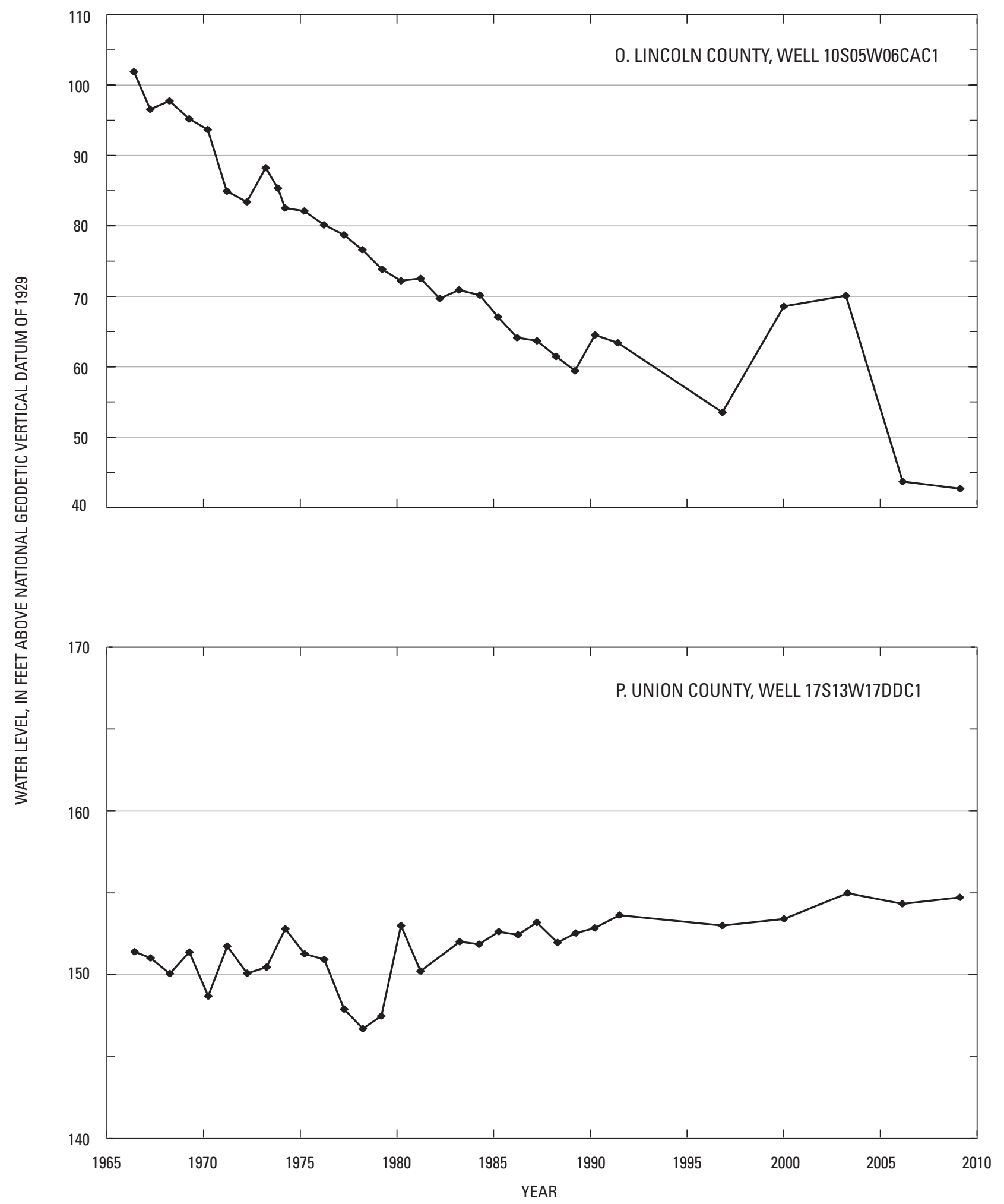

Figure 7. Water-level hydrographs for selected wells completed in the Cockfield aquifer in southern Arkansas.-Continued 


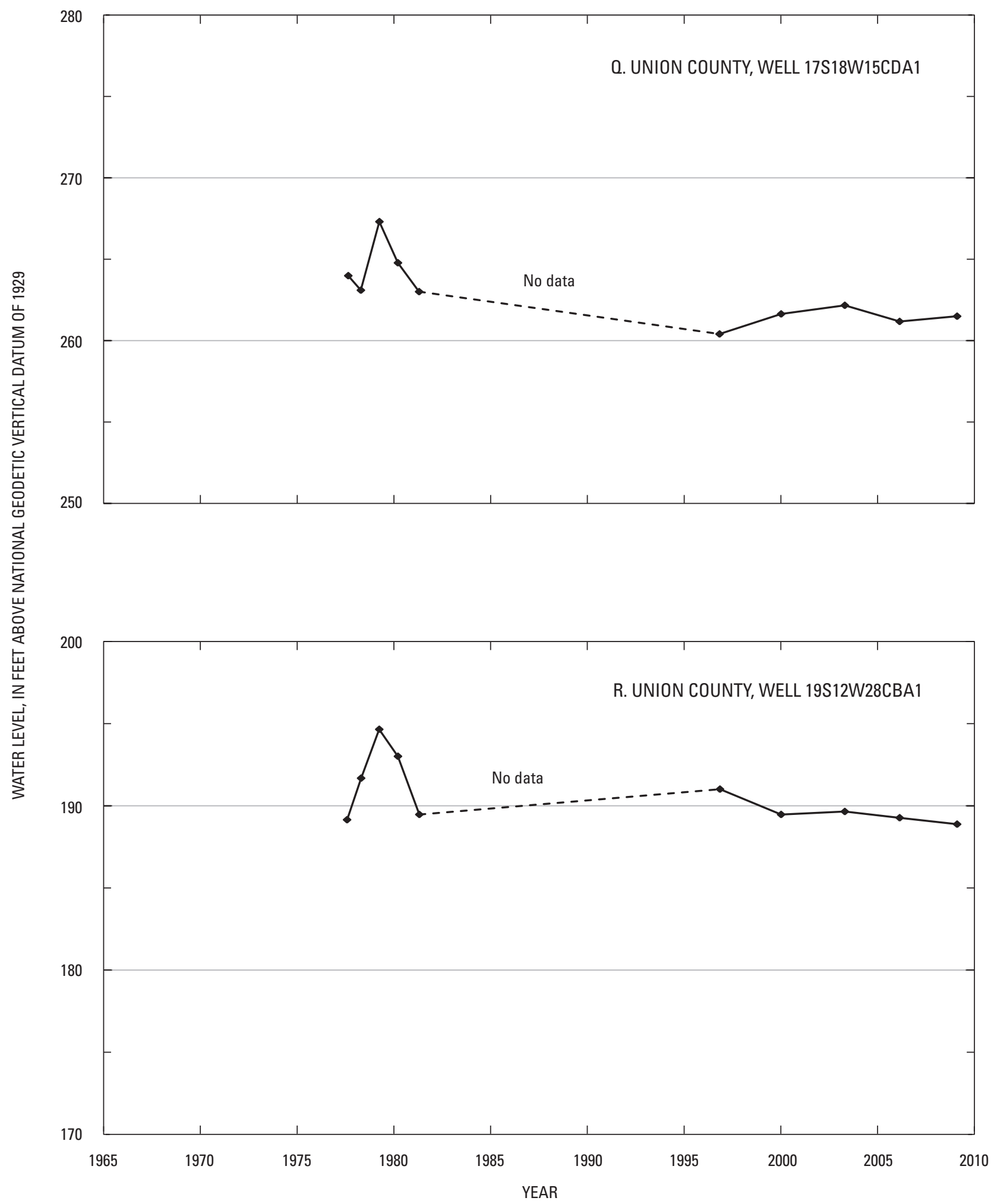

Figure 7. Water-level hydrographs for selected wells completed in the Cockfield aquifer in southern Arkansas.-Continued 


\section{Wilcox Aquifer}

\section{Hydrogeologic Setting}

The Wilcox aquifer is composed of the Wilcox Group of Upper Paleocene age and is distributed throughout the Mississippi Embayment including most of southern and eastern Arkansas. The group is part of a north-northeast trending syncline, which plunges to the south-southeast, approximately centered beneath the Mississippi River (fig. 3). The Wilcox aquifer in central Arkansas is not extensively used, and waterlevel data are insufficient to determine the potentiometric surface. Because water-level altitude data are discontinuous, the potentiometric surface of the Wilcox aquifer is constructed in two parts; one in southern Arkansas and the other in northeastern Arkansas. The Wilcox Group in southern Arkansas is undifferentiated, while in northeastern Arkansas, the Wilcox Group is divided into three units: Flour Island Formation, Fort Pillow Sand, and Old Breastworks Formation (table 1).

The Wilcox Group in the southern area consists of interbedded layers of clay, sandy clay, sand, and lignite. Sand beds generally are thin and are not continuous over large areas. In most of the southern area, the Wilcox Group overlies the Midway Group and is overlain by terrace deposits and alluvium of Quaternary age or crops out. The Wilcox Group becomes progressively thicker downslope from the outcrop, ranging in thickness from a few feet in the outcrop to about $750 \mathrm{ft}$ at the center of the syncline (Albin, 1964). The Wilcox aquifer comprises water-yielding strata within the basal sand beds of the Wilcox Group in southern Arkansas.

The Wilcox Group in most of the northeastern area consists of thin interbedded layers of lignitic sand and clays. The Wilcox Group crops out at or near Crowleys Ridge in Clay, Greene, and Craighead Counties (Broom and Lyford, 1981). East of Crowleys Ridge, the Wilcox Group, including the Fort Pillow Sand and the Old Breastworks Formation, contains a sand bed of $200 \mathrm{ft}$ or more in thickness (Petersen and others, 1985), which is referred to as the "1,400-foot sand" (Ryling, 1960; Plebuch, 1961) or the "lower Wilcox aquifer" (Hosman and others, 1968). The Wilcox aquifer in the northeastern area is confined above by a clay bed of the Wilcox Group and underlain by a clay bed of the Wilcox Group or by the Midway Group.

Within Crowleys Ridge, part of the Wilcox aquifer is perched and hydrologically separated from the aquifer in the surrounding Mississippi Alluvial Plain. Four water-level measurements were made from wells completed in this perched portion of the Wilcox aquifer, two in Green County and two in Clay County.

Recharge to the aquifer occurs in locations where the Wilcox Group crop outs or subcrops. The Wilcox Group crops out in southern Arkansas in discontinuous, 1- to 3-mile (mi) wide bands along the western edge of the aquifer. In subcrop areas, the Wilcox Group is overlain by terrace deposits and alluvium of Quaternary age. Terrace deposits may attain thicknesses of $40 \mathrm{ft}$, and as much as $60 \mathrm{ft}$ of alluvium overlie the Wilcox Group in some of the major river valleys. In northeastern Arkansas, the Wilcox Group crops out along a narrow, discontinuous band along the western edge of Crowleys Ridge (not shown at map scales used in this report).

Recharge to the Wilcox aquifer in the southern area occurs by infiltration of rainfall in the outcrop areas and by inflow from overlying terrace and alluvial deposits. Discharge flows into streams in the outcrop area, to overlying formations where the aquifer is confined, and to wells (Westerfield, 1994). Well depths range from $14 \mathrm{ft}$ within the recharge area in Hempstead County to $533 \mathrm{ft}$ in Ouachita County. Well yields range from 10 to $100 \mathrm{gal} / \mathrm{min}$ (Schrader and Joseph, 2000).

Recharge to the Wilcox aquifer in the northeastern area occurs by infiltration of rainfall in the outcrop areas along the western side of Crowleys Ridge. Discharge occurs from well withdrawals (Westerfield, 1994). Well depths range from $120 \mathrm{ft}$ on Crowleys Ridge in Greene County to $1,885 \mathrm{ft}$ in Lee County. Well yields range from 100 to 2,000 gal $/ \mathrm{min}$ (Schrader and Joseph, 2000).

\section{Hydraulic Properties}

Specific capacity and transmissivity values are extremely variable for the Wilcox aquifer. The following values are based on single-well pump tests and multiple-well aquifer tests (Pugh, 2008). Specific capacity values ranged from 0.25 $\mathrm{gal} / \mathrm{min} / \mathrm{ft}$ to $641 \mathrm{gal} / \mathrm{min} / \mathrm{ft}$ with a median of $21.1 \mathrm{gal} / \mathrm{min} / \mathrm{ft}$. Transmissivity values ranged from $30 \mathrm{ft}^{2} / \mathrm{d}$ to $32,000 \mathrm{ft}^{2} / \mathrm{d}$ with a median of $8,170 \mathrm{ft}^{2} / \mathrm{d}$. Hydraulic conductivity values were not provided by any of the well tests associated with the Wilcox aquifer. Pugh (2008) estimated a hydraulic conductivity value for the Wilcox aquifer by dividing the mean transmissivity value $\left(10,700 \mathrm{ft}^{2} / \mathrm{d}\right)$ by the maximum aquifer thickness $(1,100 \mathrm{ft})$, providing an estimated hydraulic conductivity value of $9.7 \mathrm{ft} / \mathrm{d}$.

\section{Water Use}

Reported withdrawals from the Wilcox aquifer in Arkansas totaled 27.0 Mgal/d during 2005 (fig. 8), most of which occurred in the northeastern area (Holland, 2007). Withdrawals from 1975 through 2005 have remained relatively constant, between 21.0 Mgal/d and 27.0 Mgal/d, except in 1990 (30.9 $\mathrm{Mgal} / \mathrm{d}$ ) and 1995 (41.0 Mgal/day). During the reporting years of 1990 and 1995, the increase in reported water use is attributed to withdrawals by a power generation plant that was operating during this time period (T.W. Holland, U.S. Geological Survey written commun., 2009). In the southern area, the primary use of water from the aquifer was for domestic supplies, usually from wells in or near the outcrop areas. In the northeastern area, the primary use of water from the aquifer was for public supplies, but the aquifer is also important locally as a source of water for commercial, domestic, and industrial users. 


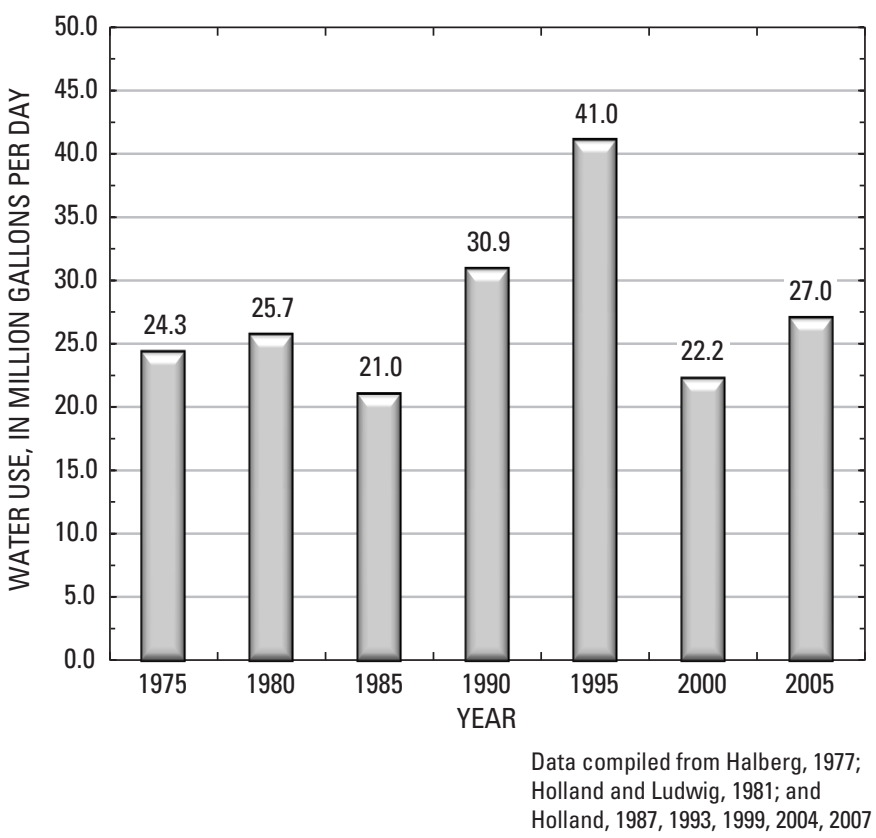

Figure 8. Water use from the Wilcox aquifer in Arkansas, 19752005.

\section{Potentiometric Surface}

The potentiometric-surface maps show the altitude of the water surface in tightly cased wells screened in the Wilcox aquifer (figs. 9 and 10). The maps are based upon water-level data collected from 57 wells during February 2009, 16 of the wells were in the southern area and the remaining 41 wells were in the northeastern area. The direction of groundwater flow is perpendicular to the contours in the direction of decreasing water level.

The direction of groundwater flow in the southern area (fig. 9) is generally to the east, except around two cones of depression, one in Nevada County and the other in Clark County, and around two mounds of elevated water levels, one in Hot Spring County and the other in Hempstead County. Water flows into the cone of depression in Nevada County from all directions. The direction of water flow toward the cone of depression in Clark County is generally from the north, west, and south. The direction of water flow from the northern mound in Hot Spring County is generally to the south and east with some to the north. The direction of water flow from the southwestern mound in Hempstead County is generally to the south and east. The lowest water-level altitude measured in the southern area was $147 \mathrm{ft}$ at the center of the cone of depression near the Ouachita River in Clark County. The highest water-level altitude measured was $400 \mathrm{ft}$ at the center of the potentiometric-surface mound in an outcrop area of Hempstead County (appendix 3).

The direction of groundwater flow in the northeastern area (fig. 10) is generally to the south and southeast except in the northern part of the area (Clay, Greene, and Craighead Counties) where the flow is in a westerly direction towards
Paragould. Groundwater withdrawals have altered the natural direction of flow near centers of pumping at Paragould and West Memphis (Joseph, 1998). The lowest water-level altitude measured in the northeastern area was $114 \mathrm{ft}$ near West Memphis in Crittenden County; the highest water-level altitude measured was $368 \mathrm{ft}$ on Crowleys Ridge in Clay County.

Crowleys Ridge is an erosional remnant of Cretaceous and Tertiary rocks covered with loess deposits. Crowleys Ridge varies from 0.5 to $12 \mathrm{mi}$ wide, rises 250 to $550 \mathrm{ft}$ above the surrounding Mississippi Alluvial Plain, and extends approximately $150 \mathrm{mi}$ southwest and south from southeastern Missouri to east-central Arkansas. Water levels measured in wells on Crowleys Ridge are higher than measurements collected in the surrounding Mississippi Alluvial Plain because of the higher altitude of the Wilcox aquifer underlying Crowleys Ridge and the influence of direct recharge from outcrops and subcrops on the ridge. Water-level measurements collected on Crowleys Ridge (four wells) were not considered in the construction of the potentiometric surface. The waters of the remnant Wilcox Group deposits, locally considered the Upper Wilcox aquifer, within Crowleys Ridge tend to be perched at higher altitudes than the surrounding Mississippi Alluvial Plain, and control points were too few for contouring.

\section{Water-Level Trends}

\section{Water-Level Difference from 2003 to 2009}

Water-level difference maps for the Wilcox aquifer in Arkansas (figs. 11 and 12) were constructed using 53 waterlevel measurements made during 2003 (Yeatts, 2004) and 2009. Positive values indicate a rise and negative values indicate a decline in water level. In figures 11 and 12, rises in the water level are indicated using upward pointing, blue triangles; while declines in the water level are indicated using downward pointing, red triangles. The triangles are scaled to the relative value of the rise or decline in water level. Waterlevel differences do not necessarily equate to water-level trends, but are intended to show where water levels have increased or decreased between 2003 and 2009.

The difference in water levels from 2003 to 2009 in the southern area (fig. 11) ranged from -17.7 to $16.0 \mathrm{ft}$ with the largest decline $(17.7 \mathrm{ft})$ in water level in Nevada County, and the largest rise (16.0 ft) in water level in Hempstead County. Water levels rose in the northern and eastern parts of the southern area (eight wells in Hempstead, Hot Spring, Clark, and Ouachita Counties), and the water levels in the southern part of the area declined (five wells in Hempstead and Nevada Counties) (appendix 5).

The differences in water levels from 2003 to 2009 in the northeastern area (fig. 12) ranged from -21.7 to $1.3 \mathrm{ft}$, with the largest decline $(21.7 \mathrm{ft})$ in water level in Greene County, and the largest rise $(1.3 \mathrm{ft})$ in water level in Crittenden County. Four well in the northeastern area had rising water levels, 35 


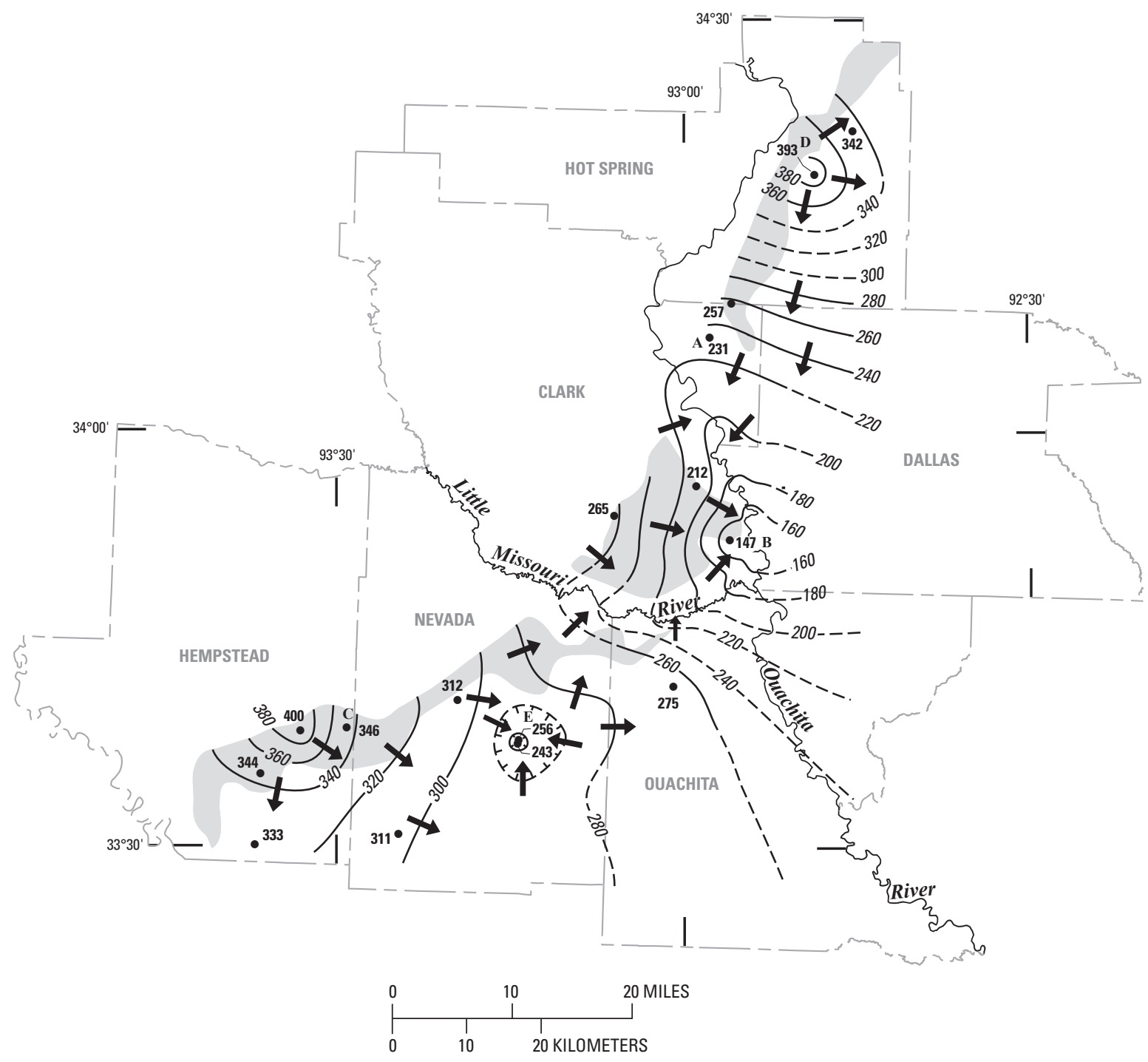

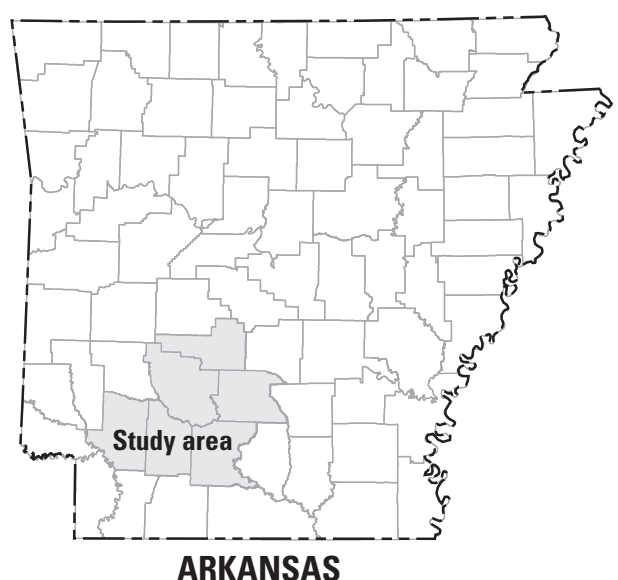

ARKANSAS

\section{EXPLANATION}

Outcrop of Wilcox Group (from Hosman, 1988)

- 180- - Potentiometric contour-Shows altitude at which water level would have stood in tightly cased wells. Hachures indicate depression. Dashed where approximately located. Contour interval 20 feet. Datum is National Geodetic Vertical Datum of 1929

General direction of groundwater flow

${ }^{A}{ }_{231}$ Well completed in Wilcox aquifer, southern Arkansas-Number is water-level altitude. Letter, where present, corresponds to hydrograph in figure 13

Figure 9. Potentiometric surface of the Wilcox aquifer in southern Arkansas, 2009. 


\section{EXPLANATION}

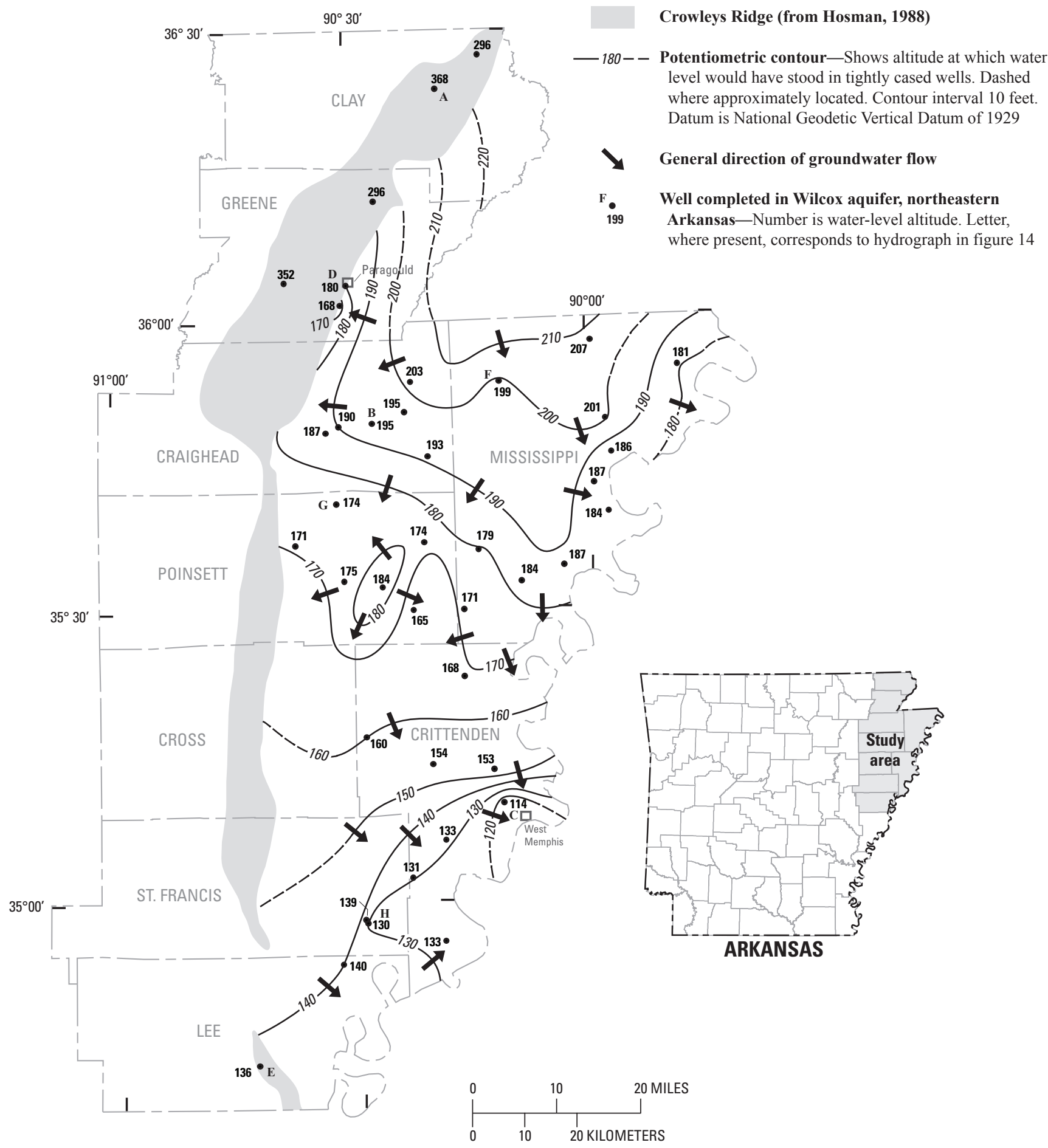

Figure 10. Potentiometric surface of the Wilcox aquifer in northeastern Arkansas, 2009. 

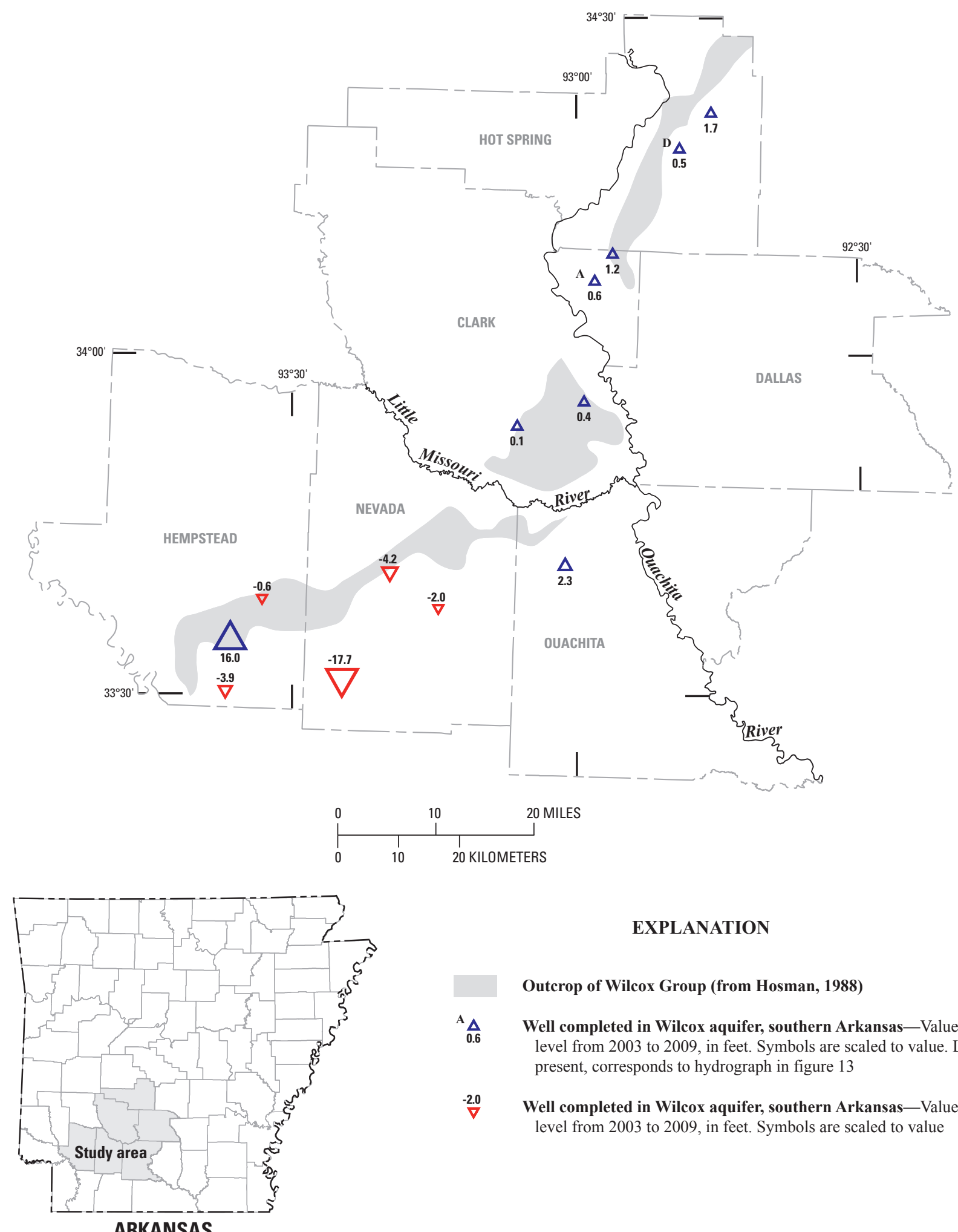

EXPLANATION

Outcrop of Wilcox Group (from Hosman, 1988)

${ }_{0.6}^{A}$ Well completed in Wilcox aquifer, southern Arkansas-Value is rise in water level from 2003 to 2009, in feet. Symbols are scaled to value. Letter where present, corresponds to hydrograph in figure 13

$\stackrel{-2.0}{\nabla}$ Well completed in Wilcox aquifer, southern Arkansas-Value is decline in water level from 2003 to 2009, in feet. Symbols are scaled to value

Figure 11. Water-level difference from 2003 to 2009 for the Wilcox aquifer in southern Arkansas. 


\section{EXPLANATION}

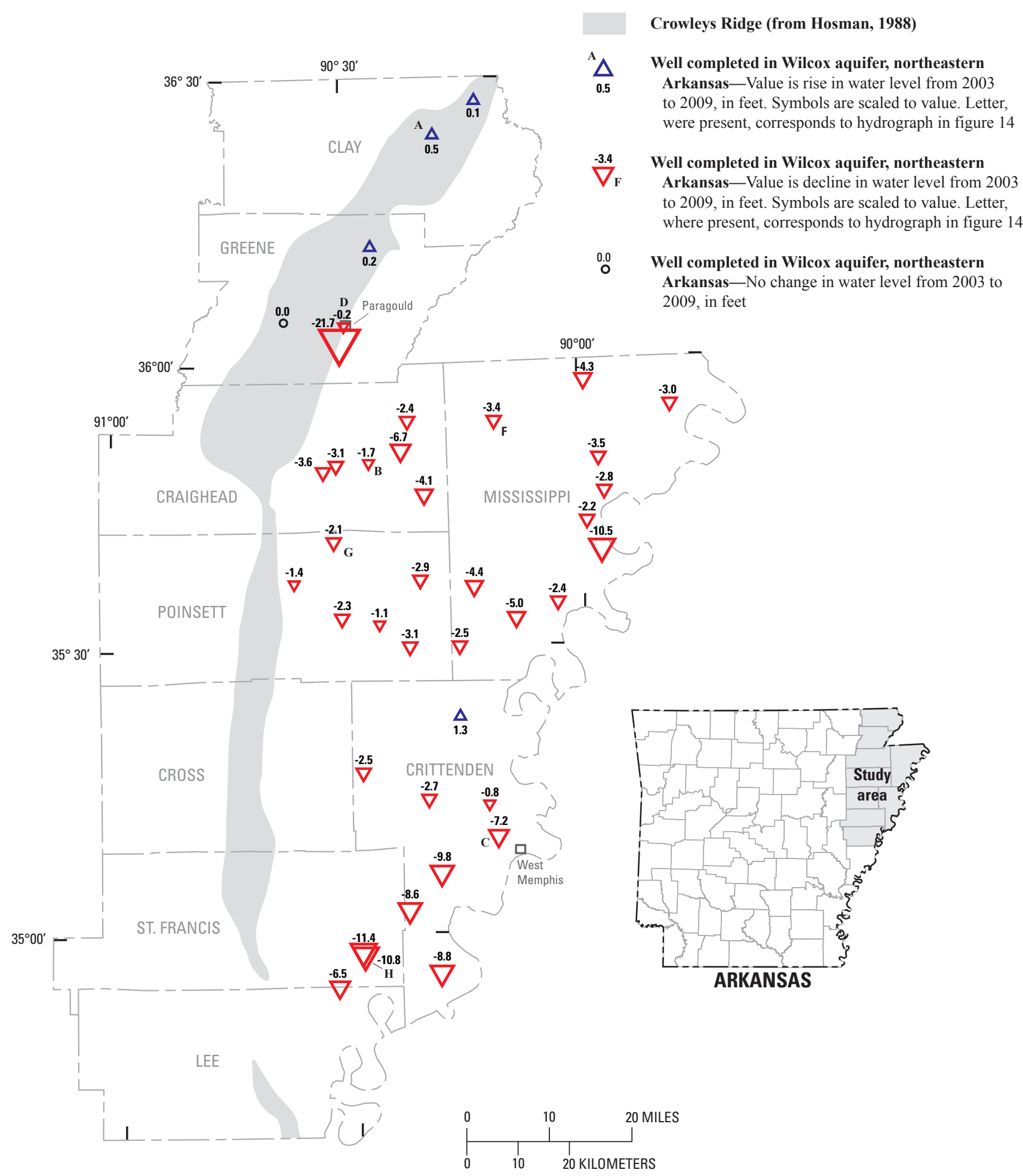

Figure 12. Water-level difference from 2003 to 2009 for the Wilcox aquifer in northeastern Arkansas. 
had declining water levels, and the remaining well had no change in water level. Water levels declined throughout the northeastern area with the exception of one well in Crittenden County. Three other wells, one in Greene County and two in Clay County, also indicate a rise in water levels from 2003 to 2009. These three wells are located within the upper, perched part of the Wilcox aquifer on Crowleys Ridge (appendix 6).

\section{Long-Term Hydrographs}

Hydrographs from 42 wells with a minimum of 20 years of USGS water-level measurements were constructed (10 in the southern area and 32 in the northeastern area). Selected hydrographs are shown in figures 13-14 with locations indicated on figures 9-12. The minimum 20-year period of record was used to evaluate long-term trends not dominated by variations in climate and localized pumping rates on water levels in a single well. A trend line using linear regression was calculated for the period from 1990 to 2009 . The slope of the trend line represents the computed annual decline or rise in water level during the 20 -year period. A statistical summary of the number of wells, the range of the annual rise or decline in water level for the county, the mean, the median, and the range of the $\mathrm{R}^{2}$ values for each county are listed in table 3 . Negative values denote a decline in water level. The statistical summary for Clay, Hempstead, and St. Francis Counties was for a single well in each county.

Mean annual water-level rise and decline data for the period from 1990 to 2009 varied by county. In the southern area, Hot Spring County mean annual water-level rose $0.15 \mathrm{ft} /$ $\mathrm{yr}$, and mean annual declines between $0.03 \mathrm{ft} / \mathrm{yr}$ and $0.71 \mathrm{ft} / \mathrm{yr}$ were computed for Clark, Hempstead, and Nevada Counties. In the northeastern area, Greene County mean annual waterlevel rose $0.46 \mathrm{ft} / \mathrm{yr}$, and mean annual declines between 0.03 $\mathrm{ft} / \mathrm{yr}$ and $2.12 \mathrm{ft} / \mathrm{yr}$ were computed for Clay, Craighead, Crittenden, Lee, Mississippi, Poinsett, and St. Francis Counties.

Hydrographs for the southern area indicate water-level changes in individual walls ranged from rises of $0.44 \mathrm{ft} /$ yr to declines of $1.68 \mathrm{ft} / \mathrm{yr}$ over the 20-year period (fig. 13). Hydrograph A, well 07S18W20ABB2 in Clark County (fig. 13), shows approximately a $6 \mathrm{ft}$ increase in water level over the period of record. This well is unconfined and is located in the subcrop, receiving vertical recharge. Hydrograph $\mathrm{B}$, well 10S18W10DDB1, also in Clark County (fig. 13), is located at the eastern edge of the outcrop and is under semiconfined conditions, receiving limited vertical recharge. This hydrograph shows a general decline through most of the period of record. Hydrographs A and B demonstrate the variability within this area caused by different confining conditions.

Table 3. Range, mean, and median of annual rise/decline in water level by county for wells completed in the Wilcox aquifer in Arkansas, 1990-2009.

[Annual rise or decline in water level for each well is calculated using linear regression; negative value indicates decline; positive value indicates rise; R2: coefficient of determination ]

\begin{tabular}{|c|c|c|c|c|c|}
\hline County & Number of wells & $\begin{array}{l}\text { Range or values of } \\
\text { annual rise (+) or } \\
\text { decline (-) in water } \\
\text { level (feet/year) }\end{array}$ & $\begin{array}{l}\text { Mean annual rise (+) } \\
\text { or decline (-) in wa- } \\
\text { ter level (feet/year) }\end{array}$ & $\begin{array}{c}\text { Median annual rise } \\
(+) \text { or decline }(-) \text { in } \\
\text { water level (feet/ } \\
\text { year) }\end{array}$ & $\begin{array}{l}\text { Range of } R^{2} \text { values } \\
\text { for trend lines }\end{array}$ \\
\hline \multicolumn{6}{|c|}{ Southern area } \\
\hline Clark & 5 & -0.33 to 0.44 & -0.03 & -0.22 & 0.10 to 0.82 \\
\hline Hempstead $^{1}$ & 1 & -0.07 & -0.07 & -0.07 & 0.32 \\
\hline Hot Spring & 2 & 0.11 to 0.18 & 0.15 & 0.15 & 0.53 to 0.56 \\
\hline Nevada & 2 & -1.68 to 0.26 & -0.71 & -0.71 & 0.32 to 0.68 \\
\hline \multicolumn{6}{|c|}{ Northeastern area } \\
\hline Clay $^{1}$ & 1 & -0.03 & -0.03 & -0.03 & 0.30 \\
\hline Craighead & 4 & -0.80 to -0.47 & -0.61 & -0.58 & 0.29 to 0.70 \\
\hline Crittenden & 8 & -2.16 to -0.69 & -1.38 & -1.41 & 0.55 to 0.93 \\
\hline Greene & 2 & 0.40 to 0.51 & 0.46 & 0.46 & 0.26 to 0.61 \\
\hline Lee & 2 & -1.83 to -0.80 & -1.31 & -1.31 & 0.89 to 0.99 \\
\hline Mississippi & 8 & -1.53 to -0.55 & -0.89 & -0.80 & 0.32 to 0.95 \\
\hline Poinsett & 4 & -1.79 to -0.18 & -0.99 & -0.99 & 0.07 to 0.98 \\
\hline St. Francis ${ }^{1}$ & 1 & -2.12 & -2.12 & -2.12 & 0.91 \\
\hline
\end{tabular}

${ }^{1}$ County included only one well with 20 or more years of measurements. 


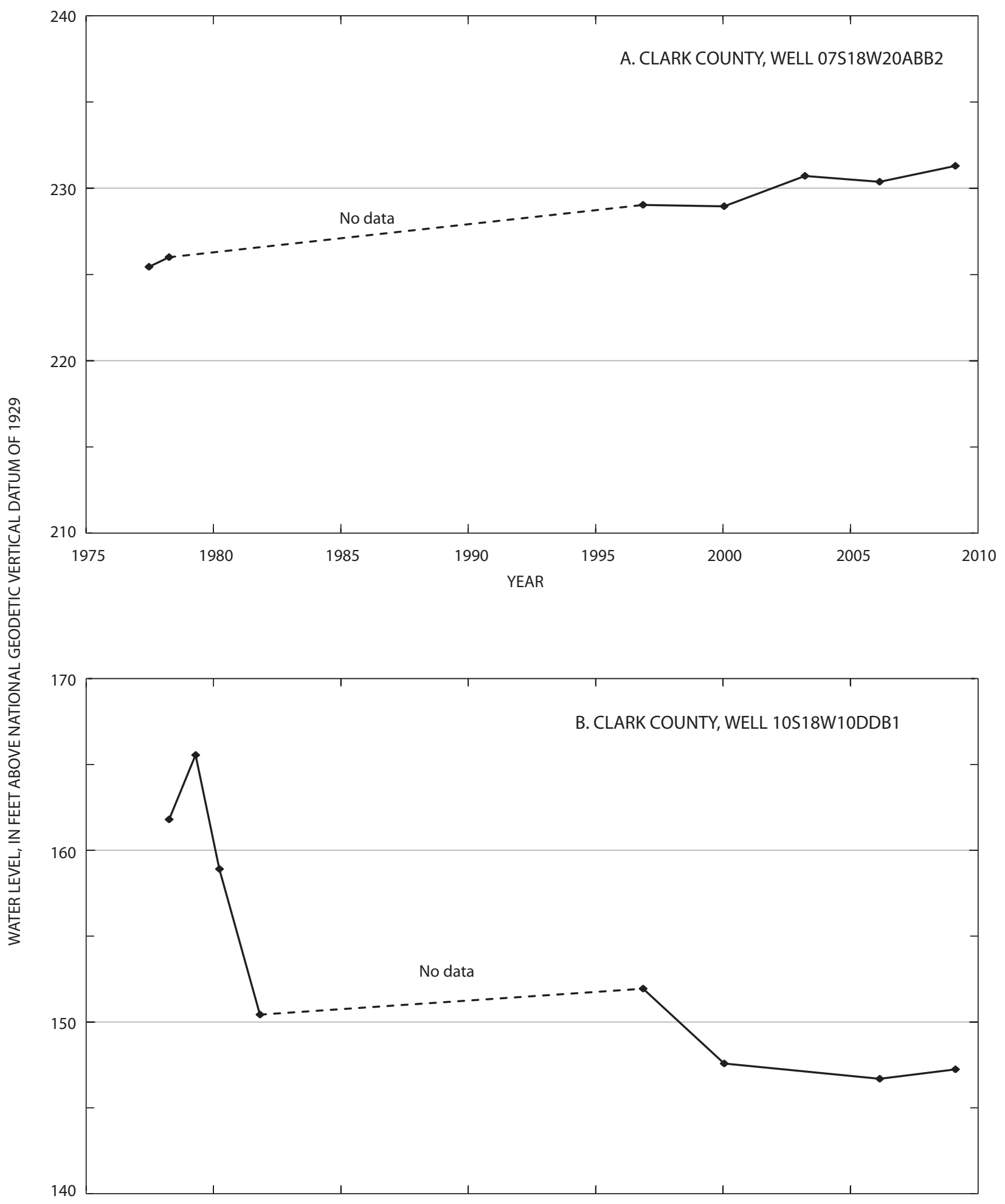

Figure 13. Water-level hydrographs for selected wells completed in the Wilcox aquifer in southern Arkansas. 


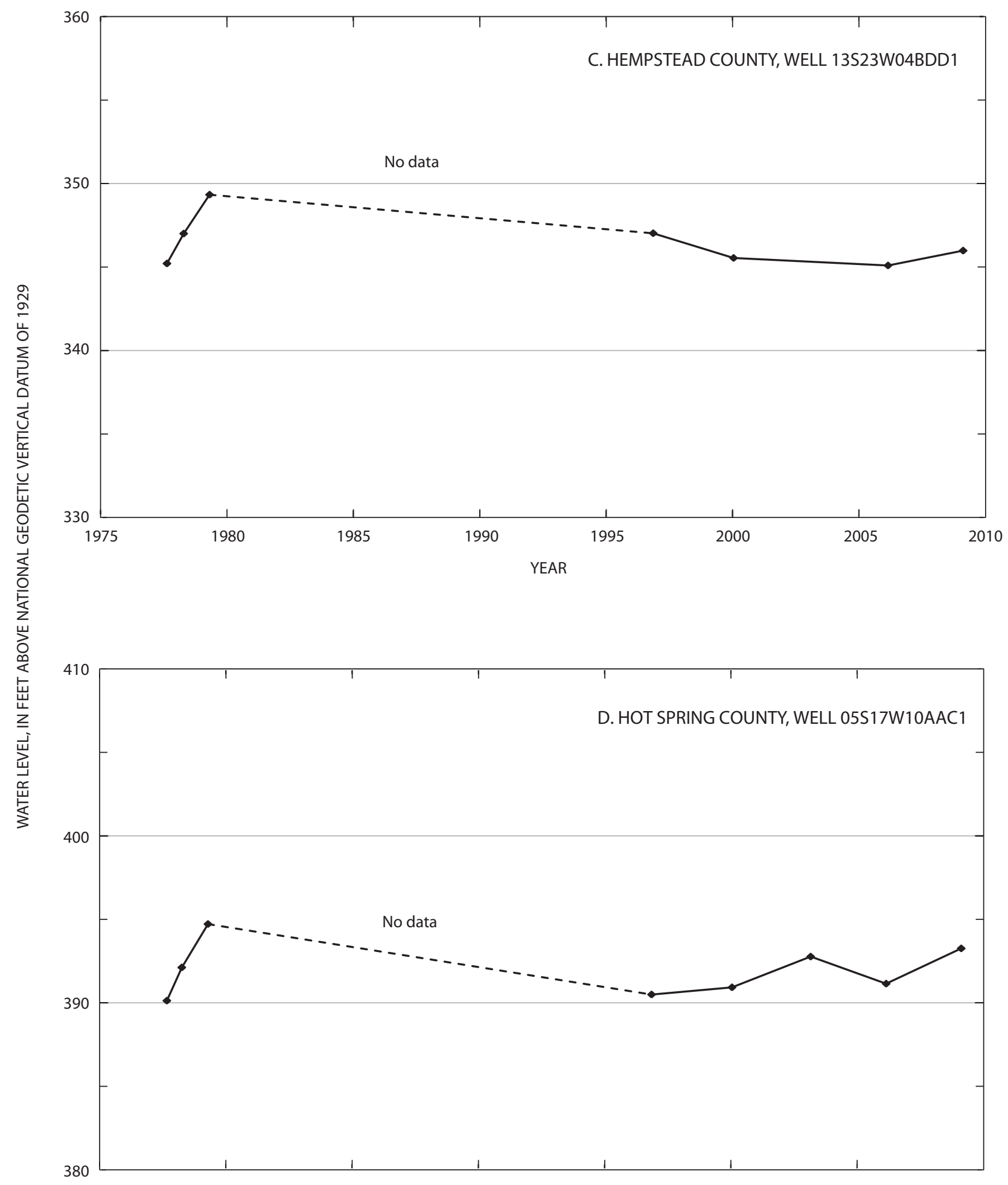

Figure 13. Water-level hydrographs for selected wells completed in the Wilcox aquifer in southern Arkansas.-Continued 


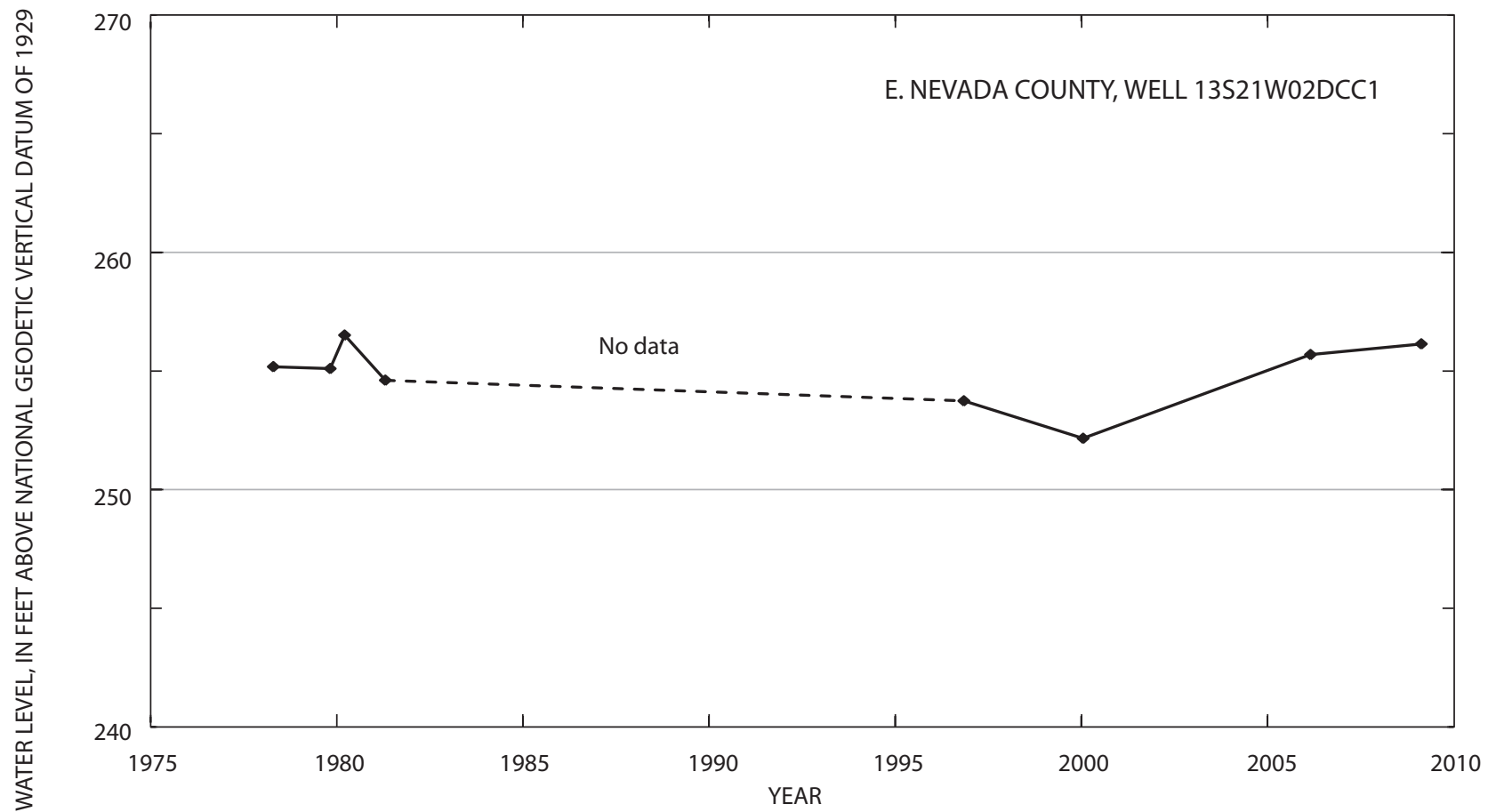

Figure 13. Water-level hydrographs for selected wells completed in the Wilcox aquifer in southern Arkansas.-Continued

Hydrographs for the northeastern area indicate waterlevel changes in individual wells ranged from rises of $0.51 \mathrm{ft} /$ yr to declines of $2.16 \mathrm{ft} / \mathrm{yr}$ over the 20 -year period (fig.14). Note there is an inconsistency between the long-term hydrograph data (fig. 14-D and table 3) and the 2003 to 2009 waterlevel difference data for Greene County (fig. 12 and appendix 6). The summary of long-term hydrograph data for Greene County indicates a slight rise in water levels because only two wells have 20 or more years of data. The analysis of long-term hydrograph data for Greene County does not include well $16 \mathrm{~N} 05 \mathrm{E} 13 \mathrm{BAB} 1$, which has the decline of $21.7 \mathrm{ft}$ in the 2003 to 2009 water-level difference data, because the well does not have 20 or more years of water-level measurements. Three hydrographs (fig. 14) indicate declining water levels in the
Wilcox aquifer in counties located on the eastern Arkansas border. Hydrograph C, well 06N09E07CAC1 in Crittenden County, shows a decline for the period of record and supports the existence of the cone of depression near West Memphis. This well has an annual decline of $1.57 \mathrm{ft} / \mathrm{yr}$ for the period 1990 to 2009 . The annual decline is in reasonable agreement with the difference from 2003 to 2009 (fig. 12) of $-7.2 \mathrm{ft}$ or $-1.2 \mathrm{ft} / \mathrm{yr}$. Hydrograph E, well 01N04E09DCC1 in Lee County, shows a decline for the period of record and has an annual decline of $1.83 \mathrm{ft} / \mathrm{yr}$ for the period 1990 to 2009 . Hydrograph F, well 15N09E31ACD1 in Mississippi County, shows a general decline for the period of record and has an annual decline of $0.77 \mathrm{ft} / \mathrm{yr}$ for the period 1990 to 2009 . 


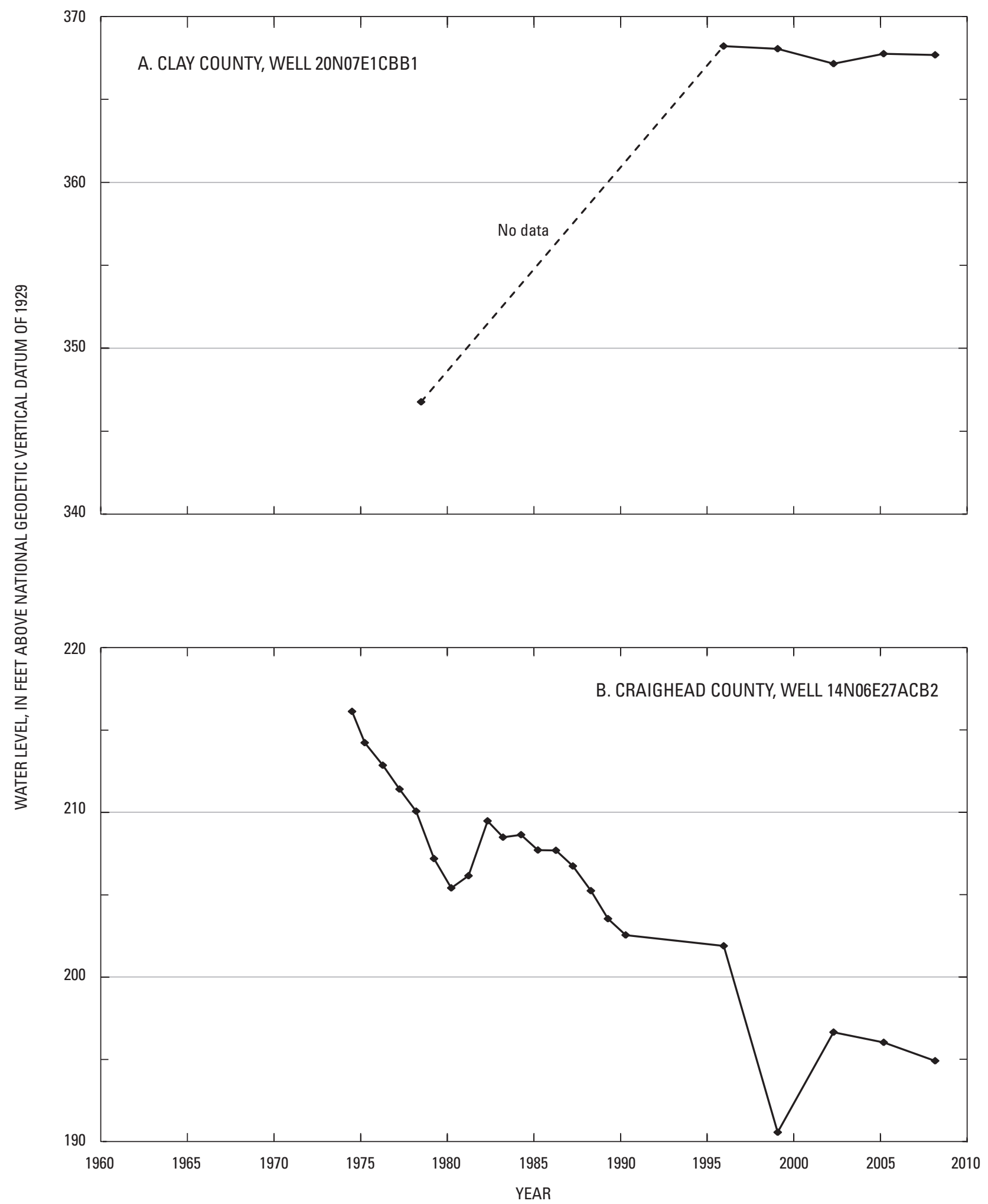

Figure 14. Water-level hydrographs for selected wells completed in the Wilcox aquifer in northeastern Arkansas. 


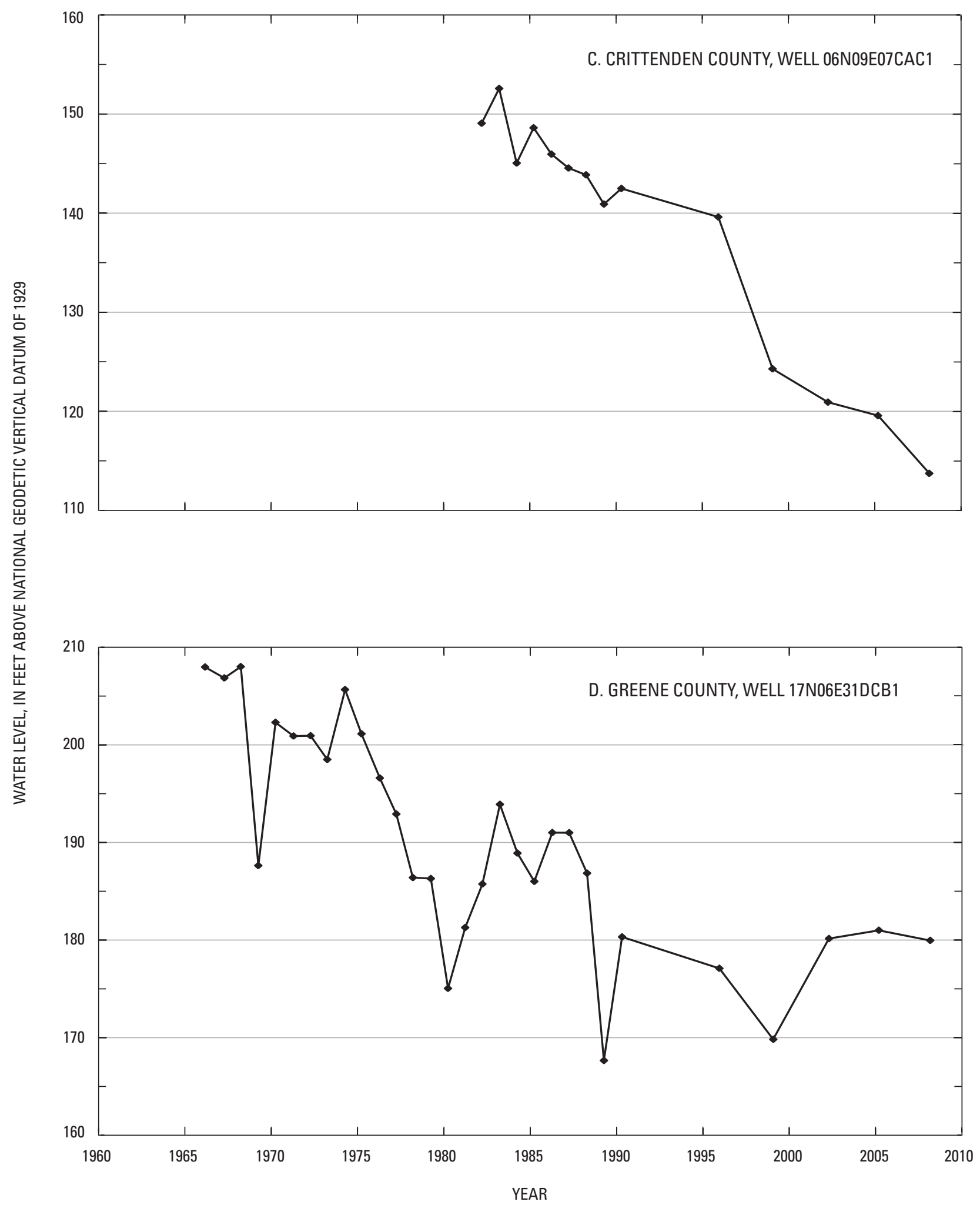

Figure 14. Water-level hydrographs for selected wells completed in the Wilcox aquifer in northeastern Arkansas. - Continued 


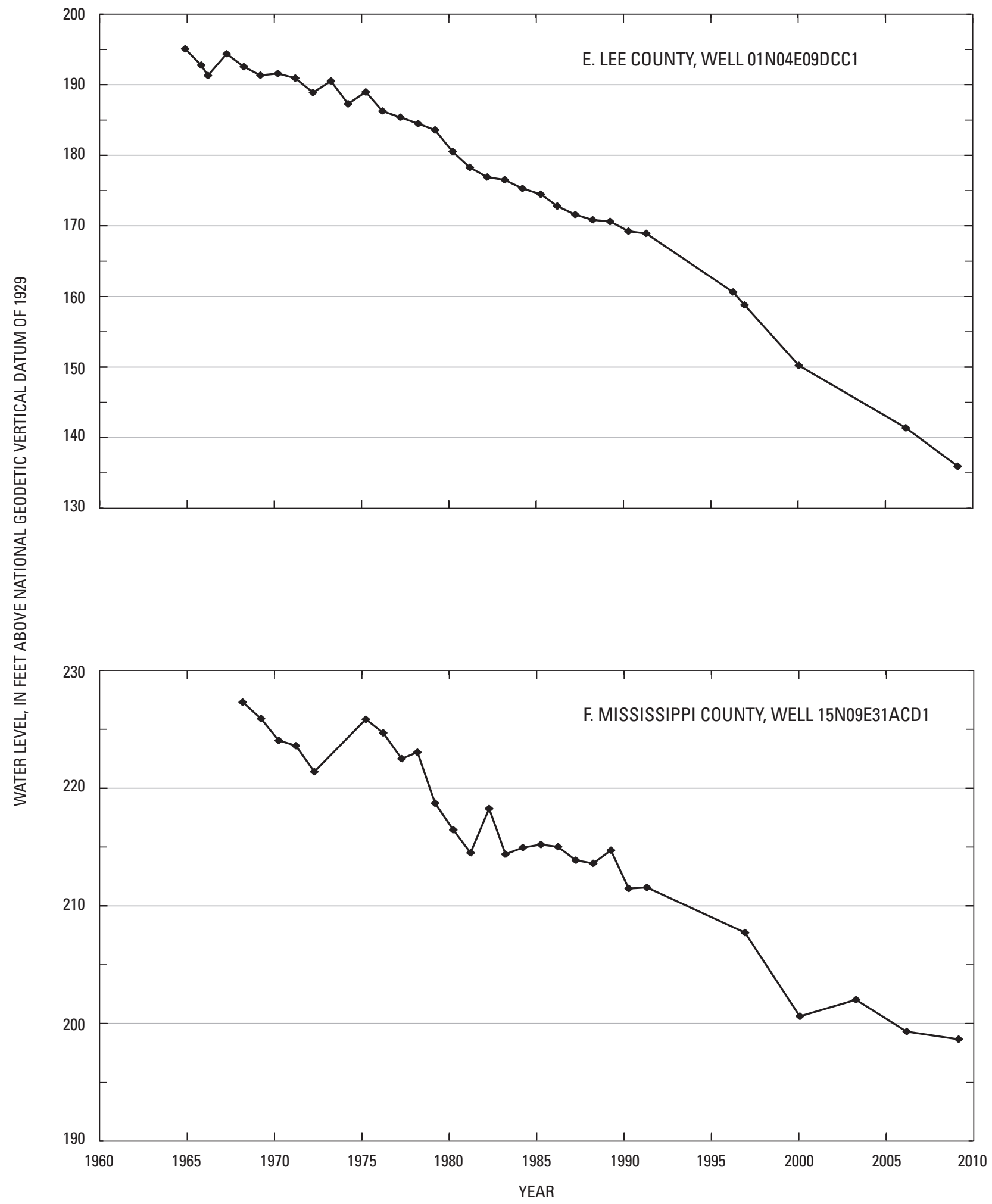

Figure 14. Water-level hydrographs for selected wells completed in the Wilcox aquifer in northeastern Arkansas.-Continued 


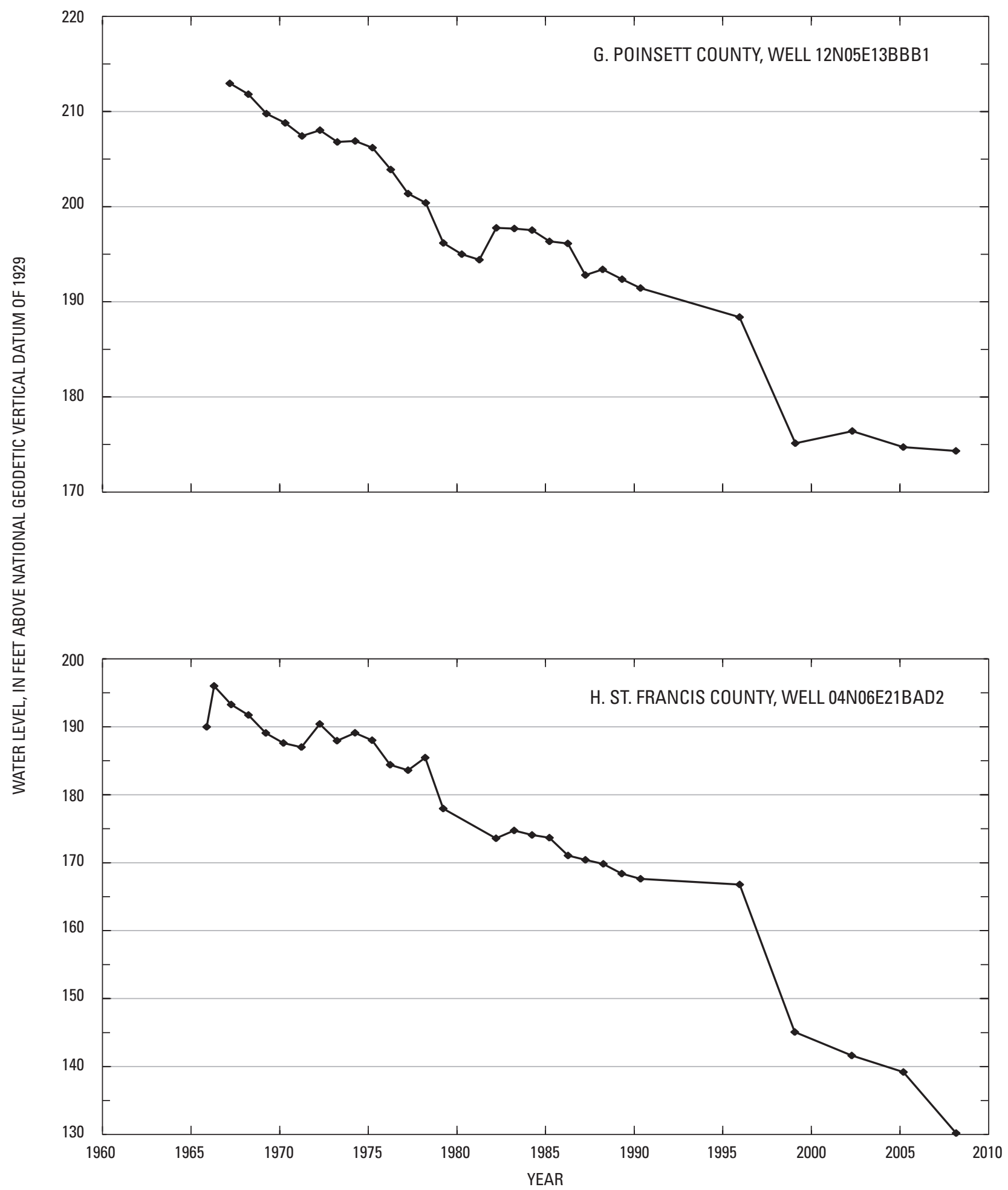

Figure 14. Water-level hydrographs for selected wells completed in the Wilcox aquifer in northeastern Arkansas. - Continued 


\section{Summary}

Eocene-age sand beds near the base of the Cockfield Formation of the Claiborne Group constitute the aquifer known locally as the Cockfield aquifer. Upper Paleocene-age sand beds within the lower parts of the Wilcox Group constitute the aquifer known locally as the Wilcox aquifer. In 2005, reported water withdrawals from the Cockfield aquifer in Arkansas totaled 16.1 million gallons per day, while reported water withdrawals from the Wilcox aquifer in Arkansas totaled 27.0 million gallons per day. Major withdrawals from these units were for industrial and public water supplies with lesser but locally important withdrawals for commercial, domestic, and agricultural uses.

During February 2009, 56 water-level measurements were made in wells completed in the Cockfield aquifer and 57 water-level measurements were made in wells completed in the Wilcox aquifer. The results from the 2009 water-level measurements are presented in potentiometric-surface maps and in combination with previous years' water-level measurements.

Trends in water-level change over time within the two aquifers are investigated using water-level difference maps and well hydrographs. Water-level difference maps were constructed for each aquifer using the difference between depth to water measurements made in 2003 and 2009. Well hydrographs for each aquifer were constructed for wells with 20 or more years of historical water-level data. The hydrographs were evaluated individually using linear regression to calculate the annual rise or decline in water levels and by aggregating the regression results by county and statistically summarizing for the range, mean, and median water-level change in each county.

The 2009 potentiometric surface of the Cockfield aquifer map indicates the regional direction of groundwater flow generally towards the east and southeast, except in two areas of intense groundwater withdrawals that have developed into cones of depression. The lowest water-level altitude measured was 43 feet in Lincoln County; the highest water-level altitude measured was 351 feet in Columbia County.

A water-level difference map was constructed from 54 wells completed in the Cockfield aquifer within Arkansas. The largest rise in water level (14.9 feet) was in Drew County. The largest decline (27.4 feet) was in Lincoln County. Seven wells had a rise in water level, and the remaining 47 wells had a decline in water level for the 6-year period. The largest declines in water levels have occurred along Arkansas' eastern and southern borders.

Hydrographs for 33 wells with 20 or more years of historical water-level data for the Cockfield aquifer were developed. Examination of the hydrographs is divided into three geographic areas: the area south and west of the Ouachita River, the area between the Ouachita and Saline Rivers, and the area east of the Saline River. The hydrographs in the area south and west of the Ouachita River are relatively flat indicating only a small, 1- to 3-foot drop in water levels over the 30- to 40-year period. The hydrographs in the area between the Ouachita and Saline Rivers display mixed results ranging from a decline of approximately 20 feet to rises of approximately 2 feet over the period of record. The hydrographs in the area east of the Saline River show declining water levels over their period of record ranging from approximately 60 feet to approximately 5 feet.

County summaries of the linear regression analysis of the 33 well hydrographs for the Cockfield aquifer indicate water level changes in individual wells ranged from a rise of approximately $0.11 \mathrm{ft} / \mathrm{yr}$ to a decline of approximately of $1.46 \mathrm{ft} / \mathrm{yr}$ over the 20-year period. Cleveland and Columbia Counties have mean annual rises 0.11 and $0.03 \mathrm{ft} / \mathrm{yr}$ respectively. Wells in Arkansas, Ashley, Bradley, Calhoun, Chicot, Desha, Drew, Lincoln, and Union Counties have mean annual declines ranging from 0.02 to $1.46 \mathrm{ft} / \mathrm{yr}$.

The potentiometric-surface for the Wilcox aquifer is presented using two maps, one southern Arkansas and another for northeastern Arkansas, because of the absence of water-level data in the central part of the State. The direction of groundwater flow in the southern area is generally the east, except around two cones of depression and around two mounds of elevated water levels. The lowest water-level altitude measured in the southern area was 147 feet in Clark County; the highest water-level altitude measured was 400 feet in Hempstead County. The direction of groundwater flow in the northeastern area is generally to the south and southeast except in an area of large groundwater withdrawals that has altered the flow to a westerly direction. The lowest water-level altitude measured in the northeastern area was 114 feet near West Memphis in Crittenden County; the highest water-level altitude measured was 368 feet on Crowleys Ridge in Clay County.

Water-level difference maps for the Wilcox aquifer in Arkansas were constructed using water-level measurements collected from 53 wells made during 2003 and 2009. In the southern area, the largest decline in water level (17.7 feet) was in Nevada County, and the largest rise in water level (16.0 feet) was in Hempstead County. Water levels rose in the northern and eastern parts of the southern area, but declined in the southern part of the area with the exception of one well in Hempstead County. The largest water-level decline in the northeastern area was in Greene County (21.7 feet), and the largest rise was in Crittenden County (1.3 feet). Water levels declined throughout the northeastern area with the exception of one well in Crittenden County. Three other wells, one in Green County and two in Clay County, also indicate a rise in water levels; but these are located within the upper, perched part of the Wilcox aquifer on Crowleys Ridge which is hydrologically disconnected from the Wilcox aquifer within the surrounding Mississippi Alluvial Plain.

Mean annual water-level rise and decline data for the period 1990-2009 varied by county. In the southern area, Hot Spring County's mean annual water-level rose $0.15 \mathrm{ft} / \mathrm{yr}$, and mean annual declines between $0.03 \mathrm{ft} / \mathrm{yr}$ and $0.71 \mathrm{ft} / \mathrm{yr}$ were computed for Clark, Hempstead, and Nevada Counties. In the 
northeastern area, Greene County's mean annual water-level rose $0.46 \mathrm{ft} / \mathrm{yr}$ and mean annual declines between $0.03 \mathrm{ft} / \mathrm{yr}$ and $2.12 \mathrm{ft} / \mathrm{yr}$ were computed for Clay, Craighead, Crittenden, Lee, Mississippi, Poinsett, and St. Francis Counties. Hydrographs from 42 wells completed in the Wilcox aquifer were constructed (10 in the southern area and 32 in the northeastern area). Hydrographs for the southern area indicate water-level changes in individual wells ranged from rises of $0.44 \mathrm{ft} / \mathrm{yr}$ to declines of $1.68 \mathrm{ft} / \mathrm{yr}$ over the 20 -year period. Hydrographs for the northeastern area indicate water-level changes in individual wells ranged from rises of $0.51 \mathrm{ft} / \mathrm{yr}$ for declines of $2.16 \mathrm{ft} /$ yr over the 20-year period.

\section{References}

Ackerman, D.J., 1987, Generalized potentiometric surface of the aquifers in the Cockfield Formation, southeastern Arkansas, spring 1980: U.S. Geological Survey WaterResources Investigations Report 87-4212, scale 1:500,000, 1 sheet.

Albin, D.R., 1964, Geology and ground-water resources of Bradley, Calhoun, and Ouachita Counties, Arkansas: U.S. Geological Survey Water-Supply Paper 1779-G, 32 p.

Arthur, J.K., and Taylor, R.E., 1990, Definition of the geohydrologic framework and preliminary simulation of groundwater flow in the Mississippi Embayment aquifer system, Gulf Coastal Plain, United States: U.S. Geological Survey Water-Resources Investigations Report 86-4364, 97 p.

Broom, M.E., and Lyford, F.P., 1981, Alluvial aquifer of the Cashe and St. Francis River Basins, northeastern Arkansas: U.S. Geological Survey Open-File Report 81-476, 48 p.

Fenneman, N.M., and Johnson, D.W., 1946, Physical divisions of the United States (Map): Washington, D.C., U.S. Geological Survey.

Halberg, H.N., 1977, Use of water in Arkansas, 1975: Arkansas Geological Commission Water Resources Summary Number 9, 28 p.

Hart, R.M., Clark, B.R., and Bolyard, S.E., 2008, Digital surfaces and thicknesses of selected hydrogeologic units within the Mississippi Embayment Regional Aquifer Study (MERAS): U.S. Geological Survey Scientific Investigations Report 2008-5098, 33 p.

Helsel, D.R., and Hirsch, R.M., 1992, Statistical methods in water resources: New York, N.Y., Elsevier Science Publishing Co., 522 p.

Holland, T. W., 1987, Use of water in Arkansas, 1985: Arkansas Geological Commission Water Resources Summary Number 6, $30 \mathrm{p}$.
Holland, T.W., 1993, Use of Water in Arkansas, 1990: U.S. Geological Survey Open-File Report 93-48, pamphlet.

Holland, T.W., 1999, Water use in Arkansas, 1995: U.S. Geological Survey Open-File Report 99-188, 1 sheet.

Holland, T.W., 2004, Estimated water use in Arkansas, 2000: U.S. Geological Survey Scientific Investigations Report 2004-5230, 31 p.

Holland, T.W., 2007, Water use in Arkansas, 2005: U.S. Geological Survey Scientific Investigations Report 2007-5241, $32 \mathrm{p}$.

Holland, T.W., and Ludwig, A.H., 1981, Use of water in Arkansas, 1980: Arkansas Geological Commission Water Resources Summary Number 14, 30 p.

Hosman, R.L., Long, A.T., Lambert, T.W., and others, 1968, Tertiary aquifers in the Mississippi embayment: U.S. Geological Survey Professional Paper 448-D, 29 p.

Hosman, R.L., and Weiss, J.S., 1991, Geohydrologic units of the Mississippi Embayment and Texas Coastal Uplands aquifer systems, South-Central United States: U.S. Geological Survey Professional Paper 1416-B, 19 p.

Hosman, R.L., 1982, Outcropping Tertiary units in southern Arkansas: U.S. Geological Survey Miscellaneous Investigations Series I-1405, 1 sheet.

Hosman, R.L., 1988, Geohydrologic framework, Gulf Coastal Plain: U.S. Geological Survey Hydrologic Investigations Atlas HA-695, 2 sheets.

Joseph, R.L., 1998, Potentiometric surface of the Cockfield aquifer in southeastern Arkansas and the Wilcox aquifers in southern and northeastern Arkansas, October 1996-July 1997: U.S. Geological Survey Water-Resources Investigations Report 98- 4084, 19 p.

Onellion, F.E., and Criner, J.H., Jr., 1955, Ground-water resources of Chicot County, Arkansas: Arkansas Geological and Conservation Commission Water Resources Circular No. 3, 27 p.

Petersen, J.C., Broom, M.E., and Bush, W.V., 1985, Geohydrologic units of the Gulf Coastal Plain in Arkansas: U.S. Geological Survey Water-Resources Investigations Report 85-4116, 20 p.

Plebuch, R.O., 1961, Fresh-water aquifers of Crittenden County, Arkansas: Arkansas Geological and Conservation Commission Water Resources Circular 8, 65 p.

Pugh, A.L., 2008, Summary of aquifer test data for Arkansas - 1940-2006: U.S. Geological Survey Scientific Investigations Report 2008-5149, 33 p. 
Ryling, R.W., 1960, Ground-water potential of Mississippi County, Arkansas: Arkansas Geological and Conservation Commission Water Resources Circular 7, 87 p.

Schrader, T.P., and Joseph, R.L., 2000, Potentiometric surfaces of aquifers in the Cockfield Formation in southeastern Arkansas and the Wilcox Group in southern and northeastern Arkansas, 2000: U. S. Geological Survey WaterResources Investigations Report 00-4206, 22 p.

Schrader, T.P., 2007, Potentiometric surfaces and water-level trends in the Cockfield and Wilcox aquifers of southern and northeastern Arkansas, 2006: U.S. Geological Survey Scientific Investigations Report 2007-5218, 27 p.

Westerfield, P.W., 1994, Potentiometric-surface maps of the Cockfield and lower Wilcox aquifers in Arkansas, 1991: U.S. Geological Survey Water-Resources Investigations Report 93-4134, scale 1:500,000, 2 sheets.

Yeatts, Daniel S., 2004, Potentiometric Surfaces in the Cockfield and Wilcox aquifers of southern and northeastern Arkansas, 2003: U.S. Geological Survey Scientific Investigations Report 2004-5169, 24 p. 
Appendixes 1-6 
Appendix 1. Water-level data collected during Feburary 2009 from wells completed in the Cockfield aquifer in southern Arkansas

[Horizontal datum is North American Datum of 1983; NGVD of 1929, National Geodetic Vertical Datum of 1929; --, missing data]

\begin{tabular}{|c|c|c|c|c|c|c|c|}
\hline Station name & $\begin{array}{l}\text { Latitude } \\
\text { (degrees, } \\
\text { minutes, } \\
\text { seconds) }\end{array}$ & $\begin{array}{l}\text { Longitude } \\
\text { (degrees, } \\
\text { minutes, } \\
\text { seconds) }\end{array}$ & $\begin{array}{c}\text { Water-level } \\
\text { altitude } \\
\text { (feet above } \\
\text { NGVD of } \\
\text { 1929) }\end{array}$ & $\begin{array}{c}\text { Depth } \\
\text { to water } \\
\text { (feet below } \\
\text { land-surface } \\
\text { datum) }\end{array}$ & $\begin{array}{l}\text { Land-surface } \\
\text { datum } \\
\text { (feet above } \\
\text { NGVD of } \\
\text { 1929) }\end{array}$ & $\begin{array}{c}\text { Well depth } \\
\text { (feet) }\end{array}$ & $\begin{array}{c}\text { Date of } \\
\text { measurement }\end{array}$ \\
\hline \multicolumn{8}{|c|}{ Arkansas County } \\
\hline 08S02W04ACA1 & 340139 & 911406 & 72 & 92.92 & 165 & 453 & $2 / 23 / 2009$ \\
\hline \multicolumn{8}{|c|}{ Ashley County } \\
\hline 15S04W26CBC1 & 332144 & 912932 & 86 & 42.28 & 128 & 409 & $2 / 20 / 2009$ \\
\hline 17S04W10BCD2 & 331417 & 913030 & 87 & 38.50 & 125 & 340 & $2 / 20 / 2009$ \\
\hline 17S04W10CBA1 & 331406 & 913033 & 91 & 33.78 & 125 & 360 & $2 / 20 / 2009$ \\
\hline 17S06W07ADA1 & 331442 & 914510 & 99 & 74.75 & 174 & 426 & $2 / 20 / 2009$ \\
\hline 18S04W19DAA2 & 330710 & 913247 & 88 & 27.79 & 116 & 356 & $2 / 20 / 2009$ \\
\hline 18S08W04BBC1 & 331038 & 915627 & 68 & 81.06 & 149 & 314 & $2 / 20 / 2009$ \\
\hline 18S08W29DDD2 & 330630 & 915629 & 70 & 69.68 & 140 & -- & $2 / 20 / 2009$ \\
\hline 19S05W12CAC1 & 330336 & 913425 & 85 & 30.03 & 115 & 320 & $2 / 20 / 2009$ \\
\hline \multicolumn{8}{|c|}{ Bradley County } \\
\hline 12S10W10BCA1 & 334108 & 920807 & 102 & 124.79 & 227 & 425 & $2 / 19 / 2009$ \\
\hline 14S10W01BAD1 & 333139 & 920522 & 86 & 145.04 & 231 & 540 & $2 / 19 / 2009$ \\
\hline 14S10W31DBA1 & 332658 & 921025 & 96 & 96.78 & 193 & 349 & $2 / 19 / 2009$ \\
\hline 14S11W35CAB1 & 332656 & 921251 & 113 & 76.71 & 190 & 320 & $2 / 19 / 2009$ \\
\hline 14S11W35DAC1 & 332650 & 921233 & 109 & 64.78 & 174 & 345 & $2 / 19 / 2009$ \\
\hline 15S12W11CAB1 & 332536 & 921858 & 131 & 23.57 & 155 & 225 & $2 / 19 / 2009$ \\
\hline 16S10W11DCB1 & 331951 & 920619 & 107 & 44.59 & 152 & 152 & $2 / 19 / 2009$ \\
\hline 16S11W11ACA1 & 332027 & 921223 & 111 & 30.00 & 141 & 140 & 2/19/2009 \\
\hline \multicolumn{8}{|c|}{ Calhoun County } \\
\hline 11S13W15BBC1 & 334560 & 922534 & 257 & 53.40 & 310 & 70 & $2 / 19 / 2009$ \\
\hline 13S13W09CBD1 & 333555 & 922638 & 194 & 37.92 & 232 & 147 & $2 / 19 / 2009$ \\
\hline 13S13W15DBA1 & 333517 & 922520 & 211 & 21.14 & 232 & 122 & $2 / 19 / 2009$ \\
\hline 14S13W11CAC1 & 333045 & 922451 & 177 & 28.12 & 205 & 105 & $2 / 19 / 2009$ \\
\hline 14S13W29ADA1 & 332829 & 922722 & 134 & 26.00 & 160 & 81 & $2 / 19 / 2009$ \\
\hline 14S13W29DAC1 & 332815 & 922729 & 126 & 13.46 & 139 & -- & $2 / 19 / 2009$ \\
\hline 14S14W21ACB1 & 332931 & 923249 & 92 & 40.13 & 132 & 160 & 2/19/2009 \\
\hline \multicolumn{8}{|c|}{ Chicot County } \\
\hline 13S03W26BBB1 & 333247 & 912301 & 67 & 72.38 & 139 & 422 & $2 / 20 / 2009$ \\
\hline 14S03W05BBA1 & 333106 & 912602 & 62 & 76.74 & 139 & 510 & $2 / 20 / 2009$ \\
\hline 15S03W21ABA1 & 332314 & 912438 & 77 & 45.33 & 122 & 400 & $2 / 20 / 2009$ \\
\hline 16S02W04BAC1 & 332027 & 911857 & 79 & 46.39 & 125 & 330 & $2 / 20 / 2009$ \\
\hline 18S02W24CDB1 & 330652 & 911547 & 81 & 48.47 & 129 & 364 & $2 / 20 / 2009$ \\
\hline 18S02W25ABB3 & 330640 & 911541 & 88 & 47.42 & 135 & 332 & $2 / 20 / 2009$ \\
\hline 18S03W14CCC1 & 330731 & 912319 & 83 & 14.62 & 98 & 320 & $2 / 20 / 2009$ \\
\hline
\end{tabular}


Appendix 1. Water-level data collected during Feburary 2009 from wells completed in the Cockfield aquifer in southern Arkansas.-Continued

[Horizontal datum is North American Datum of 1983; NGVD of 1929, National Geodetic Vertical Datum of 1929; --, missing data]

\begin{tabular}{|c|c|c|c|c|c|c|c|}
\hline Station name & $\begin{array}{l}\text { Latitude } \\
\text { (degrees, } \\
\text { minutes, } \\
\text { seconds) }\end{array}$ & $\begin{array}{l}\text { Longitude } \\
\text { (degrees, } \\
\text { minutes, } \\
\text { seconds) }\end{array}$ & $\begin{array}{l}\text { Water-level } \\
\text { altitude } \\
\text { (feet above } \\
\text { NGVD of } \\
\text { 1929) }\end{array}$ & $\begin{array}{c}\text { Depth } \\
\text { to water } \\
\text { (feet below } \\
\text { land-surface } \\
\text { datum) }\end{array}$ & $\begin{array}{l}\text { Land-surface } \\
\text { datum } \\
\text { (feet above } \\
\text { NGVD of } \\
\text { 1929) }\end{array}$ & $\begin{array}{l}\text { Well depth } \\
\text { (feet) }\end{array}$ & $\begin{array}{c}\text { Date of } \\
\text { measurement }\end{array}$ \\
\hline \multicolumn{8}{|c|}{ Cleveland County } \\
\hline 08S13W34BDA1 & 335902 & 922444 & 164 & 84.14 & 248 & 181 & $2 / 19 / 2009$ \\
\hline 09S10W17CDD1 & 335534 & 920942 & 267 & 3.42 & 270 & 361 & $2 / 19 / 2009$ \\
\hline 11S11W23BBD1 & 334449 & 921258 & 234 & 41.16 & 275 & 148 & $2 / 19 / 2009$ \\
\hline \multicolumn{8}{|c|}{ Columbia County } \\
\hline 17S20W35BBD1 & 331313 & 930914 & 351 & 10.35 & 361 & -- & $2 / 18 / 2009$ \\
\hline 19S20W34ADC1 & 330233 & 930958 & 289 & 23.65 & 313 & 39.8 & $2 / 18 / 2009$ \\
\hline 19S21W17CBB1 & 330520 & 931857 & 260 & 46.06 & 306 & 54.8 & $2 / 18 / 2009$ \\
\hline 19S21W35ADC1 & 330247 & 931513 & 251 & 4.52 & 256 & 30.1 & $2 / 18 / 2009$ \\
\hline 19S22W36DBB1 & 330245 & 932034 & 307 & 43.70 & 351 & 68.6 & $2 / 18 / 2009$ \\
\hline \multicolumn{8}{|c|}{ Desha County } \\
\hline 12S01W32DCA1 & 333628 & 911245 & 65 & 71.27 & 136 & 495 & $2 / 23 / 2009$ \\
\hline 12S03W30ADC1 & 333747 & 912611 & 80 & 72.84 & 153 & 280 & $2 / 23 / 2009$ \\
\hline 13S02W08CAA1 & 333504 & 911921 & 82 & 65.26 & 147 & 515 & $2 / 23 / 2009$ \\
\hline \multicolumn{8}{|l|}{ Drew County } \\
\hline 11S05W35DDB1 & 334216 & 913438 & 98 & 81.73 & 180 & 500 & $2 / 23 / 2009$ \\
\hline 12S08W33AAB1 & 333750 & 915551 & 70 & 102.53 & 173 & 543 & $2 / 23 / 2009$ \\
\hline 14S06W21BDC1 & 332846 & 914339 & 95 & 121.33 & 216 & -- & $2 / 23 / 2009$ \\
\hline 14S07W26BAB1 & 332754 & 914744 & 104 & 125.77 & 230 & 440 & $2 / 23 / 2009$ \\
\hline \multicolumn{8}{|c|}{ Lincoln County } \\
\hline 07S06W14BBC1 & 340709 & 914026 & 159 & 22.82 & 182 & 483 & $2 / 23 / 2009$ \\
\hline 10S05W06CAC1 & 335204 & 913918 & 43 & 127.32 & 170 & 550 & $2 / 23 / 2009$ \\
\hline \multicolumn{8}{|c|}{ Union County } \\
\hline 16S18W22DCD1 & 331913 & 925704 & 234 & 13.50 & 247 & 36 & $2 / 18 / 2009$ \\
\hline 17S12W27DCA1 & 331219 & 921929 & 158 & 12.14 & 170 & 24 & $2 / 18 / 2009$ \\
\hline 17S13W17DDC1 & 331402 & 922746 & 155 & 38.28 & 193 & 156 & $2 / 18 / 2009$ \\
\hline 17S15W31DCA2 & 331144 & 924116 & 201 & 52.12 & 253 & 110 & $2 / 18 / 2009$ \\
\hline 17S16W33BBA2 & 331229 & 924601 & 230 & 24.87 & 255 & 31 & $2 / 18 / 2009$ \\
\hline 17S18W15CDA1 & 331453 & 925723 & 262 & 28.50 & 290 & 35 & $2 / 18 / 2009$ \\
\hline 18S15W21DAC1 & 330824 & 923909 & 174 & 25.86 & 200 & 40 & $2 / 18 / 2009$ \\
\hline 19S12W28CBA1 & 330207 & 922109 & 189 & 11.12 & 200 & 25 & $2 / 18 / 2009$ \\
\hline
\end{tabular}


Appendix 2. Difference in depth to water from 2003 to 2009 in the Cockfield aquifer in southern Arkansas.

[Horizontal datum is North American Datum of 1983; NGVD of 1929, National Geodetic Vertical Datum of 1929; positive differences in depth to water indicate a rise in water levels from 2003 to 2009 whereas, negative values indicate a decline in water levels from 2003 to 2009]

\begin{tabular}{|c|c|c|c|c|c|}
\hline Station name & $\begin{array}{c}\text { Latitude } \\
\text { (degrees, } \\
\text { minutes, } \\
\text { seconds) }\end{array}$ & $\begin{array}{l}\text { Longitude } \\
\text { (degrees, } \\
\text { minutes, } \\
\text { seconds) }\end{array}$ & $\begin{array}{l}2003 \text { depth } \\
\text { to water } \\
\text { (feet below } \\
\text { land-surface } \\
\text { datum) }\end{array}$ & $\begin{array}{l}2009 \text { depth } \\
\text { to water } \\
\text { (feet below } \\
\text { land-surface } \\
\text { datum) }\end{array}$ & $\begin{array}{l}\text { Difference in } \\
\text { depth to water } \\
\text { from 2003-2009 } \\
\text { (feet) }\end{array}$ \\
\hline \multicolumn{6}{|c|}{ Arkansas County } \\
\hline 08S02W04ACA1 & 340139 & 911406 & 89.53 & 92.92 & -3.4 \\
\hline \multicolumn{6}{|c|}{ Ashley County } \\
\hline 15S04W26CBC1 & 332144 & 912932 & 41.99 & 42.28 & -0.3 \\
\hline 17S04W10BCD2 & 331417 & 913030 & 37.04 & 38.50 & -1.5 \\
\hline 17S04W10CBA1 & 331406 & 913033 & 32.96 & 33.78 & -0.8 \\
\hline 17S06W07ADA1 & 331442 & 914510 & 73.05 & 74.75 & -1.7 \\
\hline 18S04W19DAA2 & 330710 & 913247 & 25.75 & 27.79 & -2.0 \\
\hline 18S08W04BBC1 & 331038 & 915627 & 78.95 & 81.06 & -2.1 \\
\hline 19S05W12CAC1 & 330336 & 913425 & 27.24 & 30.03 & -2.8 \\
\hline \multicolumn{6}{|c|}{ Bradley County } \\
\hline 12S10W10BCA1 & 334108 & 920807 & 122.23 & 124.79 & -2.6 \\
\hline 12S10W30CAC1 & 333815 & 921046 & 10.49 & 11.21 & -0.7 \\
\hline 14S10W01BAD1 & 333139 & 920522 & 141.96 & 145.04 & -3.1 \\
\hline 14S10W31DBA1 & 332658 & 921025 & 94.86 & 96.78 & -1.9 \\
\hline 14S11W35CAB1 & 332656 & 921251 & 74.73 & 76.71 & -2.0 \\
\hline 14S11W35DAC1 & 332650 & 921233 & 63.94 & 64.78 & -0.8 \\
\hline 15S12W11CAB1 & 332536 & 921858 & 22.19 & 23.57 & -1.4 \\
\hline 16S10W11DCB1 & 331951 & 920619 & 53.2 & 44.59 & 8.6 \\
\hline 16S11W11ACA1 & 332027 & 921223 & 26.45 & 30.00 & -3.6 \\
\hline \multicolumn{6}{|c|}{ Calhoun County } \\
\hline 11S13W15BBC1 & 334560 & 922534 & 50.33 & 53.40 & -3.1 \\
\hline 13S13W09CBD1 & 333555 & 922638 & 36.47 & 37.92 & -1.5 \\
\hline 13S13W15DBA1 & 333517 & 922520 & 19.11 & 21.14 & -2.0 \\
\hline 14S13W11CAC1 & 333045 & 922451 & 27.11 & 28.12 & -1.0 \\
\hline 14S13W29ADA1 & 332829 & 922722 & 25.72 & 26.00 & -0.3 \\
\hline 14S13W29DAC1 & 332815 & 922729 & 13.53 & 13.46 & 0.1 \\
\hline 14S14W21ACB1 & 332931 & 923249 & 39.11 & 40.13 & -1.0 \\
\hline \multicolumn{6}{|c|}{ Chicot County } \\
\hline 13S03W26BBB1 & 333247 & 912301 & 70.1 & 72.38 & -2.3 \\
\hline 14S03W05BBA1 & 333106 & 912602 & 76.91 & 76.74 & 0.2 \\
\hline 15S03W21ABA1 & 332314 & 912438 & 38.2 & 45.33 & -7.1 \\
\hline 16S02W04BAC1 & 332027 & 911857 & 45.12 & 46.39 & -1.3 \\
\hline 18S02W24CDB1 & 330652 & 911547 & 45.99 & 48.47 & -2.5 \\
\hline $18 \mathrm{~S} 02 \mathrm{~W} 25 \mathrm{ABB} 3$ & 330640 & 911541 & 43.42 & 47.42 & -4.0 \\
\hline 18S03W14CCC1 & 330731 & 912319 & 13.66 & 14.62 & -1.0 \\
\hline
\end{tabular}


Appendix 2. Difference in depth to water from 2003 to 2009 in the Cockfield aquifer in southern Arkansas.-Continued [Horizontal datum is North American Datum of 1983; NGVD of 1929, National Geodetic Vertical Datum of 1929; positive differences in depth to water indicate a rise in water levels from 2003 to 2009 whereas, negative values indicate a decline in water levels from 2003 to 2009]

\begin{tabular}{|c|c|c|c|c|c|}
\hline Station name & $\begin{array}{l}\text { Latitude } \\
\text { (degrees, } \\
\text { minutes, } \\
\text { seconds) }\end{array}$ & $\begin{array}{c}\text { Longitude } \\
\text { (degrees, } \\
\text { minutes, } \\
\text { seconds) }\end{array}$ & $\begin{array}{l}2003 \text { depth } \\
\text { to water } \\
\text { (feet below } \\
\text { land-surface } \\
\text { datum) }\end{array}$ & $\begin{array}{l}2009 \text { depth } \\
\text { to water } \\
\text { (feet below } \\
\text { land-surface } \\
\text { datum) }\end{array}$ & $\begin{array}{c}\text { Difference in } \\
\text { depth to water } \\
\text { from 2003-2009 } \\
\text { (feet) }\end{array}$ \\
\hline \multicolumn{6}{|c|}{ Cleveland County } \\
\hline 08S13W34BDA1 & 335902 & 922444 & 85.46 & 84.14 & 1.3 \\
\hline 09S10W17CDD1 & 335534 & 920942 & 3.57 & 3.42 & 0.2 \\
\hline 11S11W23BBD1 & 334449 & 921258 & 40.1 & 41.16 & -1.1 \\
\hline \multicolumn{6}{|c|}{ Columbia County } \\
\hline 17S20W35BBD1 & 331313 & 930914 & 7.57 & 10.35 & -2.8 \\
\hline 19S20W34ADC1 & 330233 & 930958 & 17.71 & 23.65 & -5.9 \\
\hline 19S21W17CBB1 & 330520 & 931857 & 42.47 & 46.06 & -3.6 \\
\hline 19S21W35ADC1 & 330247 & 931513 & 0.91 & 4.52 & -3.6 \\
\hline 19S22W36DBB1 & 330245 & 932034 & 39.18 & 43.70 & -4.5 \\
\hline \multicolumn{6}{|c|}{ Desha County } \\
\hline 12S01W32DCA1 & 333628 & 911245 & 67.78 & 71.27 & -3.5 \\
\hline 12S03W30ADC1 & 333747 & 912611 & 70.89 & 72.84 & -2.0 \\
\hline 13S02W08CAA1 & 333504 & 911921 & 62.62 & 65.26 & -2.6 \\
\hline \multicolumn{6}{|c|}{ Drew County } \\
\hline 11S05W35DDB1 & 334216 & 913438 & 96.66 & 81.73 & 14.9 \\
\hline 12S08W33AAB1 & 333750 & 915551 & 99.26 & 102.53 & -3.3 \\
\hline 14S06W21BDC1 & 332846 & 914339 & 118.77 & 121.33 & -2.6 \\
\hline 14S07W26BAB1 & 332754 & 914744 & 122.87 & 125.77 & -2.9 \\
\hline \multicolumn{6}{|c|}{ Lincoln County } \\
\hline 07S06W14BBC1 & 340709 & 914026 & 19.89 & 22.82 & -2.9 \\
\hline 10S05W06CAC1 & 335204 & 913918 & 99.9 & 127.32 & -27.4 \\
\hline \multicolumn{6}{|c|}{ Union County } \\
\hline 17S12W27DCA1 & 331219 & 921929 & 9.81 & 12.14 & -2.3 \\
\hline 17S13W17DDC1 & 331402 & 922746 & 38.02 & 38.28 & -0.3 \\
\hline 17S16W33BBA2 & 331229 & 924601 & 25.25 & 24.87 & 0.4 \\
\hline 17S18W15CDA1 & 331453 & 925723 & 27.83 & 28.50 & -0.7 \\
\hline 18S15W21DAC1 & 330824 & 923909 & 24.43 & 25.86 & -1.4 \\
\hline 19S12W28CBA1 & 330207 & 922109 & 10.35 & 11.12 & -0.8 \\
\hline
\end{tabular}


Appendix 3. Water-level data collected during Feburary 2009 from wells completed in the Wilcox aquifer in southern Arkansas. [Horizontal datum is North American Datum of 1983; NGVD of 1929, National Geodetic Vertical Datum of 1929; --, missing data]

\begin{tabular}{|c|c|c|c|c|c|c|c|}
\hline Station name & $\begin{array}{l}\text { Latitude } \\
\text { (degrees, } \\
\text { minutes, } \\
\text { seconds) }\end{array}$ & $\begin{array}{c}\text { Longitude } \\
\text { (degrees, } \\
\text { minutes, } \\
\text { seconds) }\end{array}$ & $\begin{array}{c}\text { Water-level } \\
\text { altitude } \\
\text { (feet above } \\
\text { NGVD of 1929) }\end{array}$ & $\begin{array}{l}\text { Depth to water } \\
\text { (feet below } \\
\text { land-surface } \\
\text { datum }\end{array}$ & $\begin{array}{l}\text { Land-surface } \\
\text { datum } \\
\text { (feet above } \\
\text { NGVD of } \\
\text { 1929) }\end{array}$ & $\begin{array}{c}\text { Well depth } \\
\text { (feet) }\end{array}$ & $\begin{array}{c}\text { Date of } \\
\text { measurement }\end{array}$ \\
\hline \multicolumn{8}{|c|}{ Clark County } \\
\hline 07S18W03BBD1 & 340917 & 925604 & 257 & 13.36 & 270 & 47 & $2 / 17 / 2009$ \\
\hline 07S18W20ABB2 & 340652 & 925757 & 231 & 10.71 & 242 & 19 & $2 / 17 / 2009$ \\
\hline 09S18W20CBB1 & 335611 & 925905 & 212 & 17.58 & 230 & 26 & $2 / 17 / 2009$ \\
\hline 10S20W01BAC1 & 335403 & 930612 & 265 & 29.69 & 295 & 53 & $2 / 17 / 2009$ \\
\hline 10S18W10DDB1 & 335216 & 925613 & 147 & 47.76 & 195 & 215 & $2 / 17 / 2009$ \\
\hline \multicolumn{8}{|c|}{ Hempstead County } \\
\hline 13S23W04BDD1 & 333842 & 932911 & 346 & 4.02 & 350 & 14 & $2 / 17 / 2009$ \\
\hline 13S24W02DCA2 & 333829 & 933311 & 400 & 45.98 & 446 & 63 & $2 / 17 / 2009$ \\
\hline 13S24W29ACC1 & 333524 & 933635 & 344 & 27.05 & 371 & 60 & $2 / 17 / 2009$ \\
\hline 14S24W29BCA1 & 333017 & 933704 & 333 & 21.62 & 355 & 31 & $2 / 17 / 2009$ \\
\hline \multicolumn{8}{|c|}{ Hot Spring County } \\
\hline 04S16W20CBB1 & 342144 & 924532 & 342 & 2.90 & 345 & 18 & $2 / 17 / 2009$ \\
\hline 05S17W10AAC1 & 341836 & 924853 & 393 & 16.74 & 410 & 26 & $2 / 17 / 2009$ \\
\hline \multicolumn{8}{|c|}{ Nevada County } \\
\hline 12S22W24CDA1 & 334046 & 931941 & 312 & 31.73 & 344 & 41 & $2 / 18 / 2009$ \\
\hline 13S21W02DCC1 & 333754 & 931426 & 256 & 58.86 & 315 & 240 & $2 / 18 / 2009$ \\
\hline 13S21W11BDA1 & 333738 & 931432 & 243 & 25.39 & 268 & -- & $2 / 18 / 2009$ \\
\hline 14S22W19AAA1 & 333105 & 932443 & 311 & 25.92 & 337 & 75 & $2 / 18 / 2009$ \\
\hline \multicolumn{8}{|c|}{ Ouachita County } \\
\hline 12S19W11DCD1 & 334144 & 930105 & 275 & 13.25 & 288 & 533 & $2 / 18 / 2009$ \\
\hline
\end{tabular}


Appendix 4. Water-level data collected during February 2009 from wells completed in the Wilcox aquifer in northeastern Arkansas.

[Horizontal datum is North American Datum of 1983; NGVD of 1929, National Geodetic Vertical Datum of 1929]

\begin{tabular}{|c|c|c|c|c|c|c|c|}
\hline Station name & $\begin{array}{l}\text { Latitude } \\
\text { (degrees, } \\
\text { minutes, } \\
\text { seconds) }\end{array}$ & $\begin{array}{c}\text { Longitude } \\
\text { (degrees, } \\
\text { minutes, } \\
\text { seconds) }\end{array}$ & $\begin{array}{c}\text { Water- } \\
\text { level altitude } \\
\text { (feet above } \\
\text { NGVD of } \\
\text { 1929) }\end{array}$ & $\begin{array}{c}\text { Depth to } \\
\text { water } \\
\text { (feet below } \\
\text { land-surface } \\
\text { datum) }\end{array}$ & $\begin{array}{l}\text { Land- } \\
\text { surface } \\
\text { datum } \\
\text { (feet above } \\
\text { NGVD of } \\
\text { 1929) }\end{array}$ & $\begin{array}{l}\text { Well depth } \\
\text { (feet) }\end{array}$ & $\begin{array}{c}\text { Date of } \\
\text { measurement }\end{array}$ \\
\hline \multicolumn{8}{|c|}{ Clay County } \\
\hline 21N08E14CBB1 & 362716 & 901126 & 296 & 83.99 & 380 & 157 & $2 / 25 / 2009$ \\
\hline 20N07E01CBB1 & 362347 & 901703 & 368 & 92.32 & 460 & 200 & $2 / 25 / 2009$ \\
\hline \multicolumn{8}{|c|}{ Craighead County } \\
\hline 15N07E33BAD1 & 355315 & 902107 & 203 & 29.29 & 232 & 1,034 & $2 / 24 / 2009$ \\
\hline 14N07E17DCB1 & 355008 & 902202 & 195 & 37.39 & 232 & 1,070 & $2 / 24 / 2009$ \\
\hline 14N06E27ACB2 & 354858 & 902613 & 195 & 32.10 & 227 & 999 & $2 / 24 / 2009$ \\
\hline 14N05E25DCB1 & 354843 & 903029 & 190 & 43.05 & 233 & 890 & $2 / 24 / 2009$ \\
\hline 14N05E34DAA1 & 354803 & 903208 & 187 & 43.25 & 230 & 865 & $2 / 24 / 2009$ \\
\hline 13N07E14BBA2 & 354526 & 901911 & 193 & 27.79 & 221 & 1,028 & $2 / 24 / 2009$ \\
\hline \multicolumn{8}{|c|}{ Crittenden County } \\
\hline 09N08E29ADD1 & 352225 & 901516 & 168 & 56.61 & 225 & 1,564 & $2 / 26 / 2009$ \\
\hline 08N06E33CBD1 & 351614 & 902752 & 160 & 54.84 & 215 & 1,750 & $2 / 26 / 2009$ \\
\hline 07N07E14CCC1 & 351318 & 901930 & 154 & 69.20 & 223 & 1,584 & $2 / 26 / 2009$ \\
\hline 07N08E24CAB1 & 351238 & 901148 & 153 & 67.69 & 221 & 1,540 & $2 / 26 / 2009$ \\
\hline 06N09E07CAC1 & 350907 & 901042 & 114 & 96.27 & 210 & 1,470 & $2 / 26 / 2009$ \\
\hline 06N07E01ABB1 & 350520 & 901807 & 133 & 74.01 & 207 & 1,541 & $2 / 26 / 2009$ \\
\hline 05N07E29ACC1 & 350129 & 902225 & 131 & 69.35 & 200 & 1,700 & $2 / 26 / 2009$ \\
\hline 04N07E36ADB1 & 345449 & 901828 & 133 & 67.65 & 201 & 1,638 & $2 / 26 / 2009$ \\
\hline \multicolumn{8}{|c|}{ Greene County } \\
\hline 18N06E10DCD1 & 361209 & 902520 & 296 & 24.41 & 320 & 120 & $2 / 25 / 2009$ \\
\hline 17N04E36BCA1 & 360348 & 903658 & 352 & 153.39 & 505 & 311 & $2 / 25 / 2009$ \\
\hline 17N06E31DCB1 & 360328 & 902902 & 180 & 105.04 & 285 & 462 & $2 / 25 / 2009$ \\
\hline 16N05E13BAB1 & 360123 & 903026 & 168 & 122.04 & 290 & 545 & $2 / 25 / 2009$ \\
\hline \multicolumn{8}{|c|}{ Lee County } \\
\hline 03N05E01BAB1 & 345413 & 903136 & 140 & 55.94 & 196 & 1,702 & $2 / 27 / 2009$ \\
\hline 01N04E09DCC1 & 344209 & 904220 & 136 & 68.08 & 204 & 1,885 & $2 / 27 / 2009$ \\
\hline \multicolumn{8}{|c|}{ Mississippi County } \\
\hline 15N10E01ADC1 & 355712 & 895806 & 207 & 40.54 & 248 & 1,350 & $2 / 25 / 2009$ \\
\hline 15N12E23DBC1 & 355426 & 894701 & 181 & 57.21 & 238 & 1,491 & $2 / 25 / 2009$ \\
\hline 15N09E31ACD1 & 355306 & 900952 & 199 & 41.34 & 240 & 1,158 & $2 / 25 / 2009$ \\
\hline 14N11E20CCA1 & 354859 & 895626 & 201 & 39.03 & 240 & 1,518 & $2 / 25 / 2009$ \\
\hline 13N11E08DDA1 & 354528 & 895547 & 186 & 59.36 & 245 & 1,445 & $2 / 25 / 2009$ \\
\hline 13N11E31CCCC1 & 354221 & 895807 & 187 & 54.38 & 241 & 1,500 & $2 / 25 / 2009$ \\
\hline 12N11E17CDD1 & 353917 & 895618 & 184 & 60.93 & 245 & 1,500 & $2 / 25 / 2009$ \\
\hline 11N08E10AAC2 & 353538 & 901301 & 179 & 41.47 & 220 & 1,380 & $2 / 26 / 2009$ \\
\hline
\end{tabular}


Appendix 4. Water-level data collected during February 2009 from wells completed in the Wilcox aquifer in northeastern Arkansas.-Continued

[Horizontal datum is North American Datum of 1983; NGVD of 1929, National Geodetic Vertical Datum of 1929]

\begin{tabular}{|c|c|c|c|c|c|c|c|}
\hline Station name & $\begin{array}{l}\text { Latitude } \\
\text { (degrees, } \\
\text { minutes, } \\
\text { seconds) }\end{array}$ & $\begin{array}{c}\text { Longitude } \\
\text { (degrees, } \\
\text { minutes, } \\
\text { seconds) }\end{array}$ & $\begin{array}{c}\text { Water- } \\
\text { level altitude } \\
\text { (feet above } \\
\text { NGVD of } \\
\text { 1929) }\end{array}$ & $\begin{array}{c}\text { Depth to } \\
\text { water } \\
\text { (feet below } \\
\text { land-surface } \\
\text { datum) }\end{array}$ & $\begin{array}{l}\text { Land- } \\
\text { surface } \\
\text { datum } \\
\text { (feet above } \\
\text { NGVD of } \\
\text { 1929) }\end{array}$ & $\begin{array}{l}\text { Well depth } \\
\text { (feet) }\end{array}$ & $\begin{array}{c}\text { Date of } \\
\text { measurement }\end{array}$ \\
\hline \multicolumn{8}{|c|}{ Mississippi County_Continued } \\
\hline 11N10E20ADA1 & 353349 & 900213 & 187 & 48.03 & 235 & 1,417 & $2 / 25 / 2009$ \\
\hline 11N09E33AAB1 & 353214 & 900739 & 184 & 52.98 & 237 & 1,560 & $2 / 26 / 2009$ \\
\hline 10N08E17ADD1 & 352923 & 901505 & 171 & 53.52 & 225 & 1,521 & $2 / 26 / 2009$ \\
\hline \multicolumn{8}{|c|}{ Poinsett County } \\
\hline 12N05E13BBB1 & 354038 & 903059 & 174 & 47.68 & 222 & 1,071 & $2 / 24 / 2009$ \\
\hline 11N07E03BDD1 & 353629 & 901955 & 174 & 41.79 & 216 & 1,456 & $2 / 24 / 2009$ \\
\hline 11N05E06CCD1 & 353622 & 903618 & 171 & 42.88 & 214 & 992 & $2 / 24 / 2009$ \\
\hline 11N05E36AAA1 & 353234 & 903009 & 175 & 38.83 & 214 & 1,175 & $2 / 24 / 2009$ \\
\hline 11N06E35CDA3 & 353152 & 902520 & 184 & 30.97 & 215 & 1,301 & $2 / 24 / 2009$ \\
\hline 10N07E16CBB2 & 352925 & 902129 & 165 & 52.53 & 218 & 1,500 & $2 / 24 / 2009$ \\
\hline \multicolumn{8}{|c|}{ St. Francis County } \\
\hline 04N06E16CCB1 & 345712 & 902830 & 139 & 62.65 & 202 & 1,615 & $2 / 27 / 2009$ \\
\hline 04N06E21BAD2 & 345649 & 902815 & 130 & 70.79 & 201 & 1,740 & $2 / 27 / 2009$ \\
\hline
\end{tabular}


Appendix 5. Difference in depth to water from 2003 to 2009 in the Wilcox aquifer in southern Arkansas.

[Horizontal datum is North American Datum of 1983; NGVD of 1929, National Geodetic Vertical Datum of 1929; positive differences in depth to water indic ate a rise in water levels from 2003 to 2009 whereas negative values indicate a decline in water levels from 2003 to 2009]

\begin{tabular}{|c|c|c|c|c|c|}
\hline Station name & $\begin{array}{c}\text { Latitude } \\
\text { (degrees, } \\
\text { minutes, } \\
\text { seconds) }\end{array}$ & $\begin{array}{l}\text { Longitude } \\
\text { (degrees, } \\
\text { minutes, } \\
\text { seconds) }\end{array}$ & $\begin{array}{l}2003 \text { depth } \\
\text { to water } \\
\text { (feet below } \\
\text { land-surface } \\
\text { datum) }\end{array}$ & $\begin{array}{l}2009 \text { depth } \\
\text { to water } \\
\text { (feet below } \\
\text { land-surface } \\
\text { datum) }\end{array}$ & $\begin{array}{c}\text { Difference in } \\
\text { depth to water } \\
\text { from 2003-2009 } \\
\text { (feet) }\end{array}$ \\
\hline \multicolumn{6}{|c|}{ Clark County } \\
\hline 07S18W03BBD1 & 340917 & 925604 & 14.51 & 13.36 & 1.2 \\
\hline 07S18W20ABB2 & 340652 & 925757 & 11.29 & 10.71 & 0.6 \\
\hline 09S18W20CBB1 & 335611 & 925905 & 17.97 & 17.58 & 0.4 \\
\hline 10S20W01BAC1 & 335403 & 930612 & 29.75 & 29.69 & 0.1 \\
\hline \multicolumn{6}{|c|}{ Hempstead County } \\
\hline 13S24W29ACC1 & 333524 & 933635 & 43.08 & 27.05 & 16.0 \\
\hline 13S24W02DCA2 & 333829 & 933311 & 45.43 & 45.98 & -0.6 \\
\hline 14S24W29BCA1 & 333017 & 933704 & 17.70 & 21.62 & -3.9 \\
\hline \multicolumn{6}{|c|}{ Hot Spring County } \\
\hline 04S16W20CBB1 & 342144 & 924532 & 4.62 & 2.9 & 1.7 \\
\hline 05S17W10AAC1 & 341836 & 924853 & 17.23 & 16.74 & 0.5 \\
\hline \multicolumn{6}{|c|}{ Nevada County } \\
\hline 13S21W11BDA1 & 333738 & 931432 & 23.44 & 25.39 & -2.0 \\
\hline 12S22W24CDA1 & 334046 & 931941 & 27.58 & 31.73 & -4.2 \\
\hline 14S22W19AAA1 & 333105 & 932443 & 8.25 & 25.92 & -17.7 \\
\hline \multicolumn{6}{|c|}{ Ouachita County } \\
\hline 12S19W11DCD1 & 334144 & 930105 & 15.59 & 13.25 & 2.3 \\
\hline
\end{tabular}


Appendix 6. Difference in depth to water from 2003 to 2009 in the Wilcox aquifer in northeastern Arkansas.

[Horizontal datum is North American Datum of 1983; NGVD of 1929, National Geodetic Vertical Datum of 1929; positive differences in depth to water indicate a rise in water levels from 2003 to 2009 whereas negative values indicate a decline in water levels from 2003 to 2009]

\begin{tabular}{|c|c|c|c|c|c|}
\hline Station name & $\begin{array}{l}\text { Latitude } \\
\text { (degrees, } \\
\text { minutes, } \\
\text { seconds) }\end{array}$ & $\begin{array}{c}\text { Longitude } \\
\text { (degrees, } \\
\text { minutes, } \\
\text { seconds) }\end{array}$ & $\begin{array}{c}2003 \text { depth } \\
\text { to water } \\
\text { (feet below } \\
\text { land-surface } \\
\text { datum) }\end{array}$ & $\begin{array}{l}2009 \text { depth } \\
\text { to water } \\
\text { (feet below } \\
\text { land-surface } \\
\text { datum) }\end{array}$ & $\begin{array}{l}\text { Difference in } \\
\text { water level from } \\
\text { 2003-2009 } \\
\text { (feet) }\end{array}$ \\
\hline \multicolumn{6}{|c|}{ Clay County } \\
\hline 20N07E01CBB1 & 362347 & 901703 & 92.85 & 92.32 & 0.5 \\
\hline 21N08E14CBB1 & 362716 & 901126 & 84.08 & 83.99 & 0.1 \\
\hline \multicolumn{6}{|c|}{ Craighead County } \\
\hline 14N06E27ACB2 & 354858 & 902613 & 30.36 & 32.10 & -1.7 \\
\hline 15N07E33BAD1 & 355315 & 902107 & 26.87 & 29.29 & -2.4 \\
\hline 14N05E25DCB1 & 354843 & 903029 & 39.96 & 43.05 & -3.1 \\
\hline 14N05E34DAA1 & 354803 & 903208 & 39.64 & 43.25 & -3.6 \\
\hline 13N07E14BBA2 & 354526 & 901911 & 23.71 & 27.79 & -4.1 \\
\hline 14N07E17DCB1 & 355008 & 902202 & 30.74 & 37.39 & -6.7 \\
\hline \multicolumn{6}{|c|}{ Crittenden County } \\
\hline 07N08E24CAB1 & 351238 & 901148 & 66.87 & 67.69 & -0.8 \\
\hline 08N06E33CBD1 & 351614 & 902752 & 52.39 & 54.84 & -2.5 \\
\hline 07N07E14CCC1 & 351318 & 901930 & 66.46 & 69.20 & -2.7 \\
\hline 06N09E07CAC1 & 350907 & 901042 & 89.08 & 96.27 & -7.2 \\
\hline 05N07E29ACC1 & 350129 & 902225 & 60.72 & 69.35 & -8.6 \\
\hline 04N07E36ADB1 & 345449 & 901828 & 58.87 & 67.65 & -8.8 \\
\hline 06N07E01ABB1 & 350520 & 901807 & 64.25 & 74.01 & -9.8 \\
\hline 09N08E29ADD1 & 352225 & 901516 & 57.89 & 56.61 & 1.3 \\
\hline \multicolumn{6}{|c|}{ Greene County } \\
\hline 17N06E31DCB1 & 360328 & 902902 & 104.85 & 105.04 & -0.2 \\
\hline 16N05E13BAB1 & 360123 & 903026 & 100.38 & 122.04 & -21.7 \\
\hline 18N06E10DCD1 & 361209 & 902520 & 24.63 & 24.41 & 0.2 \\
\hline 17N04E36BCA1 & 360348 & 903658 & 153.38 & 153.39 & 0.0 \\
\hline \multicolumn{6}{|c|}{ Lee County } \\
\hline 03N05E01BAB1 & 345413 & 903136 & 49.44 & 55.94 & -6.5 \\
\hline \multicolumn{6}{|c|}{ Mississippi County } \\
\hline 13N11E31CCCC1 & 354221 & 895807 & 52.17 & 54.38 & -2.2 \\
\hline 11N10E20ADA1 & 353349 & 900213 & 45.62 & 48.03 & -2.4 \\
\hline 10N08E17ADD1 & 352923 & 901505 & 51.03 & 53.52 & -2.5 \\
\hline 13N11E08DDA1 & 354528 & 895547 & 56.52 & 59.36 & -2.8 \\
\hline 15N12E23DBC1 & 355426 & 894701 & 54.23 & 57.21 & -3.0 \\
\hline 15N09E31ACD1 & 355306 & 900952 & 37.98 & 41.34 & -3.4 \\
\hline 14N11E20CCA1 & 354859 & 895626 & 35.53 & 39.03 & -3.5 \\
\hline 15N10E01ADC1 & 355712 & 895806 & 36.25 & 40.54 & -4.3 \\
\hline
\end{tabular}


Appendix 6. Difference in depth to water from 2003 to 2009 in the Wilcox aquifer in northeastern Arkansas.-Continued

[Horizontal datum is North American Datum of 1983; NGVD of 1929, National Geodetic Vertical Datum of 1929; positive differences in depth to water indicate a rise in water levels from 2003 to 2009 whereas negative values indicate a decline in water levels from 2003 to 2009]

\begin{tabular}{rccccc}
\hline & $\begin{array}{c}\text { Latitude } \\
\text { (degrees, } \\
\text { minutes, } \\
\text { seconds) }\end{array}$ & $\begin{array}{l}\text { Longitude } \\
\text { (degrees, } \\
\text { minutes, } \\
\text { seconds) }\end{array}$ & $\begin{array}{c}\text { 2003 depth } \\
\text { to water } \\
\text { (feet below } \\
\text { land-surface } \\
\text { datum) }\end{array}$ & $\begin{array}{c}\text { 2009 depth } \\
\text { to water } \\
\text { (feet below } \\
\text { land-surface } \\
\text { datum) }\end{array}$ & $\begin{array}{c}\text { Difference in } \\
\text { water level from } \\
\text { 2003-2009 } \\
\text { (feet) }\end{array}$ \\
\hline \multicolumn{5}{c}{ Mississippi County-Continued } \\
\hline 11N08E10AAC2 & 353538 & 901301 & 37.09 & 41.47 & -4.4 \\
11N09E33AAB1 & 353214 & 900739 & 47.98 & 52.98 & -5.0 \\
12N11E17CDD1 & 353917 & 895618 & 50.40 & 60.93 & -10.5 \\
\hline & \multicolumn{5}{c}{ Poinsett County } \\
\hline 12N05E13BBB1 & 354038 & 903059 & 45.59 & 47.68 & -2.1 \\
11N07E03BDD1 & 353629 & 901955 & 38.92 & 41.79 & -2.9 \\
11N05E06CCD1 & 353622 & 903618 & 41.50 & 42.88 & -1.4 \\
11N05E36AAA1 & 353234 & 903009 & 36.57 & 38.83 & -2.3 \\
11N06E35CDA3 & 353152 & 902520 & 29.87 & 30.97 & -1.1 \\
10N07E16CBB2 & 352925 & 902129 & 49.40 & 52.53 & -3.1 \\
\hline & \multicolumn{5}{c}{ St. Francis County } \\
\hline 04N06E16CCB1 & 345712 & 902830 & 51.86 & \\
04N06E21BAD2 & 345649 & 902815 & 59.38 & 70.79 & -11.4 \\
\hline
\end{tabular}


Publishing support provided by:

Lafayette Publishing Service Center

For more information concerning the research described in the report: contact:

\section{U.S. Geological Survey}

Arkansas Water Science Center

401 Hardin Road

Little Rock, AR 72211-3528

(501) 228-3600

http://ar.water.usgs.gov 
